Atlas of aphids

trapped in agricultural crops
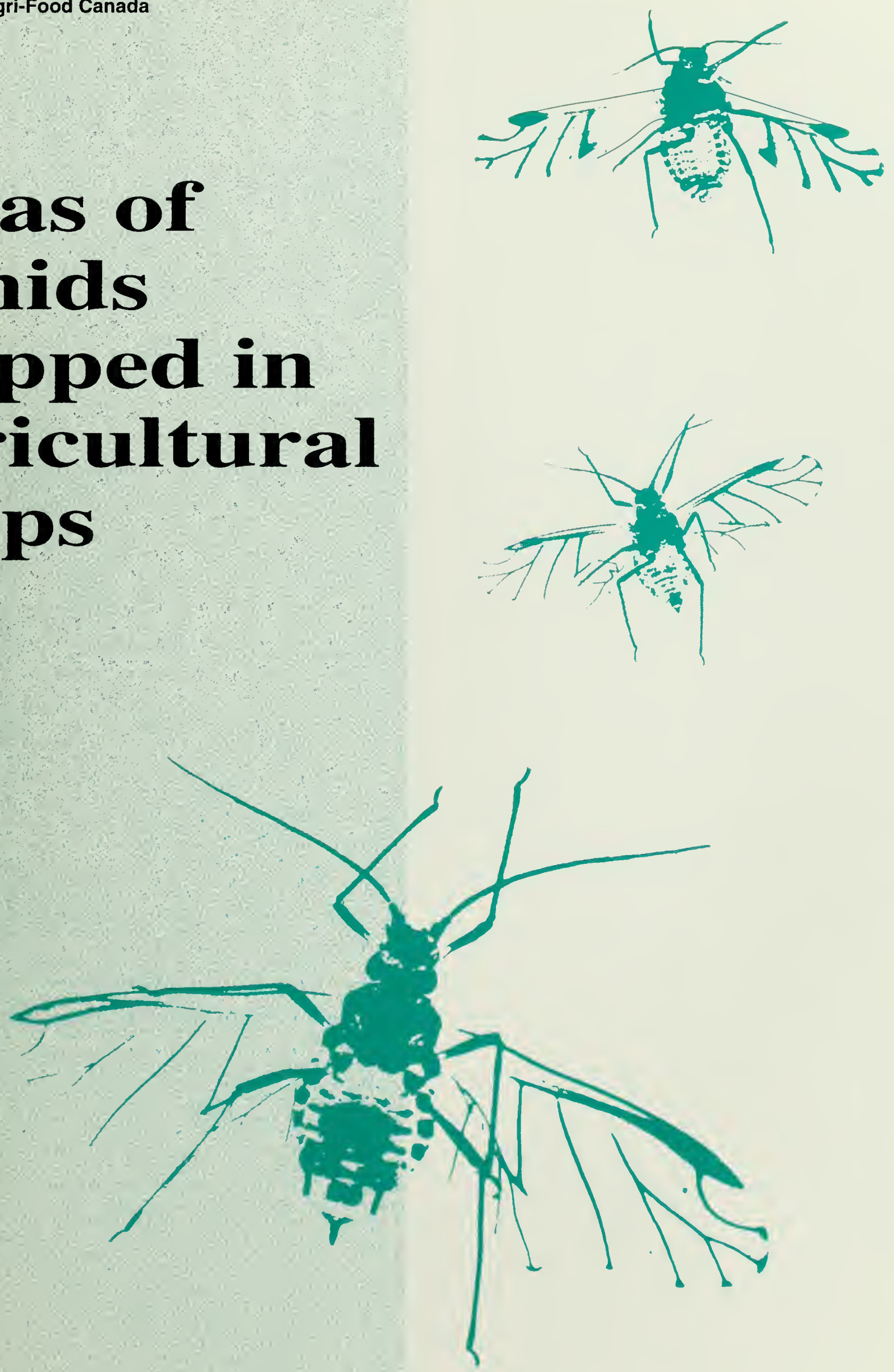
Digitized by the Internet Archive in 2011 with funding from

Agriculture and Agri-Food Canada - Agriculture et Agroalimentaire Canada 


\title{
Atlas of aphids trapped in agricultural crops
}

\author{
Lola L. Gualtieri \\ and \\ D.G.R. McLeod \\ Research Centre \\ London, Ontario
}

Research Branch

Agriculture and Agri-Food Canada

Publication 1901/E

1994 
(C) Minister of Supply and Services Canada 1994

Available in Canada through

Associated Bookstores

and other booksellers

or by mail from

Canada Communication Group - Publishing

Ottawa, Canada K1A 0S9

Cat. No. A43-1901/1994E

ISBN 0-660-15551-6

\section{Canadian Cataloguing in Publication Data}

Gualtieri, Lola L.

Atlas of aphids trapped in agricultural crops / Lola L. Gualtieri and D.G.R. McLeod. -

(Publication ; 1901/E)

Includes bibliographical references.

Issued by: Research Branch.

Issued also in French under title: Atlas des pucerons piégés dans les champs agricoles.

Cat no. A43-1901/1994E

ISBN 0-660-15551-6

1. Aphididae-Canada-Identification. I. McLeod, D. G. R. (Dougald Glenn Ross). II. Canada. Agriculture and Agri-Food Canada Research Branch. III. Title. IV. Series: Publication (Canada. Agriculture and Agri-Food Canada) ; 1901/E.

SB945.A5 1994 623.7’52’097I C94-982000-8

\section{Staff Editor}

Frances Smith

\section{Cover Design}

Richard Mallett 


\section{Contents}

Preface iv

Acknowledgments iv

Alphabetical list of aphids $v$

Description of aphid species 1

Glossary 61

Bibliography 64 


\section{Preface}

Aphids reduce the yield of agricultural crops primarily by their feeding activity or through the introduction of viruses detrimental to plant health. Preventing losses by aphids usually depends on determining the presence of aphid pest species in the crop and separating them from those aphids only incidentally recovered during monitoring.

Over 600 species of aphids have been identified in Canada, and although most are not pests, they can often confuse the identification of pest species found among the aphids retrieved during a monitoring program.

This atlas is not meant to be a definitive work on aphids in Canada, but rather a tool to be used by crop protection specialists to help them identify and separate pest species from other species not harmful to agricultural crops, or at least only incidentally present. Species are identified by visually comparing captured aphid specimens with pictures of the whole aphid and with pictures of organs or appendages that are important for identification. It should be noted that only the alate female form was used for this atlas.

A total of 60 aphid species are included in the atlas. Most aphids were trapped near London, Ontario, over a period of 7 years. The aphids were captured using yellow pan water traps adjacent to cruciferous crops or Masner traps in a general vegetable-growing area near London. Although these aphids are typical of those likely to be encountered in agricultural areas, the samples likely contain species that are dependent on the surrounding vegetation.

The aphids were tentatively identified and were then submitted for final determination to the Biological Resources Division, Centre for Land and Biological Resources Research, Ottawa, Ontario.

\section{Acknowledgments}

The assistance of Dr. R.G. Foottit and Mr. E. Maw of the Biological Resources Division, Centre for Land and Biological Resources Research, Ottawa, Ontario, is gratefully acknowledged. The work of Mr. Jerry Lambert, who took photographs of each whole aphid, is appreciated. Thanks to Mr. Ted Sawinski for contributing some of the specimens and to Dorothy Drew for her help in collecting references. Thanks also to the editor, Fran Smith, and to the graphic designer, Rick Mallett. A special debt of gratitude is owed to Dr. Tom Lowery, whose encouragement and help during the initial phases of this work were important to getting started. 


\section{Alphabetical list of aphids}

Scientific name

Acyrthosiphon pisum (Harris)

Amphorophora agathonica Hottes

Anoecia corni (Fabricius).....

Anoecia oenotherae Wilson

Aphis sp. Linnaeus

Asiphonaphis pruni Wilson \& Davis

Aulacorthum solani (Kaltenbach).

Brachycaudus (Acaudus) cardui (Linnaeus)

Brachycaudus helichrysi (Kaltenbach)

Breviconne brassicae (Linnaeus)

Calaphis betulaecolens (Fitch)

Capitophorus elaeagni (del Guercio)

Capitophorus hippophaes (Walker)

Cavariella aegopodii (Scopoli)

Chaitophorus nigrae Oestlund.

Chaitophorus populicola Thomas.

Chaitophorus populifolii neglectus

Hottes \& Frison

pea aphid

large American raspberry aphid

dogwood aphid

foxglove aphid .............................................

thistle aphid .............................................. 8

leaf-curling plum aphid .............................. 9

cabbage aphid ............................................10

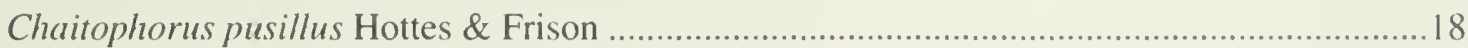

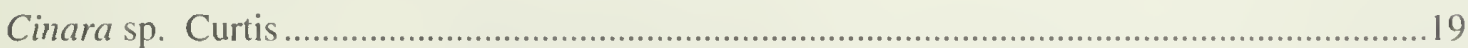

Cryptomyzus galeopsidis (Kaltenbach) .................European blackcurrant aphid....................20

Diuraphis (Holcaphis) frequens (Walker) ............................................................................21

Drepanaphis acerifoliae (Thomas) ......................painted maple aphid..............................22

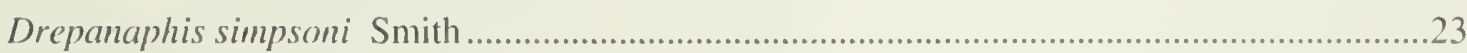

Dysaphis (Pomaphis) plantaginea (Passerini) .......rosy apple aphid.......................................24

Eucallipterus tiliae (Linnacus) ............................basswood aphid ......................................25

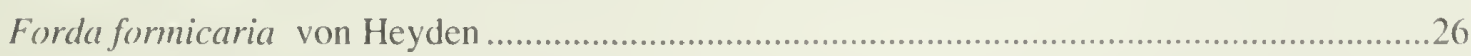

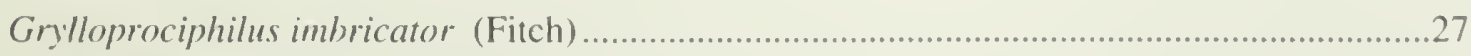

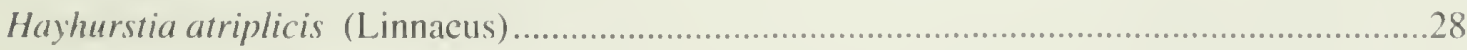

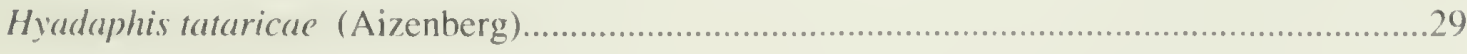

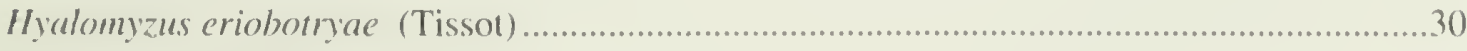

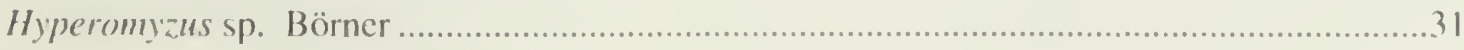

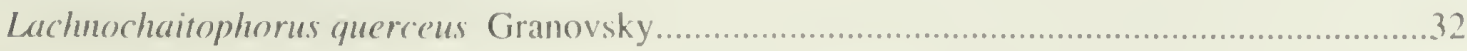

Lipaphis ensimi (Kaltenbach)

turnip aphid 
Macrosiphum (Sitobion) avenae (Fabricius)

grain aphid .34

Macrosiphum euphorbiae (Thomas)

potato aphid .35

Macrosiphum pallidum (Oestlund) .36

Mindarus abietinus Koch balsam twig aphid .37

Myzocallis (Neomyzocallis) punctata (Monell) .38

Myzus persicae (Sulzer) green peach aphid. .39

Nasonovia (Kakimia) cynosbati (Oestlund) dogberry aphid. 40

Nasonovia ribisnigri (Mosley) .currant-lettuce aphid . .41

Nearctaphis bakeri (Cowen) clover aphid .42

Nearctaphis crataegifoliae (Fitch) long-beaked clover aphid .43

Ovatus crataegarius (Walker) mint aphid .44

Pemphigus sp. Hartig .45

Periphyllus lyropictus (Kessler) Norway maple aphid. .46

Pleotrichophorus sp. Börner .47

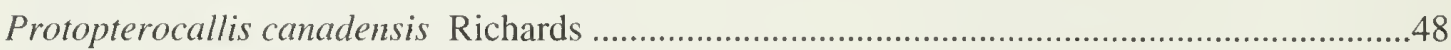

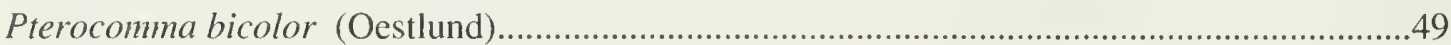

Rhodobiım porosum (Sanderson) ...........................ellow rose aphid......................................50

Rhopalosiphum insertum (Walker). apple grain aphid .51

Rhopalosiphum maidis (Fitch) corn leaf aphid. .52

Rhopalosiphum padi (Linnaeus) bird cherry-oat aphid .53

Rhopalosiphum rufiabdominale (Sasaki) rice root aphid .54

Schizaphis graminum (Rondani) greenbug .55

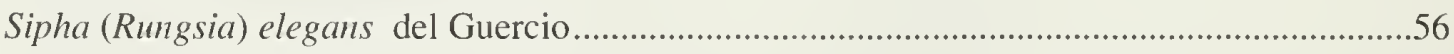

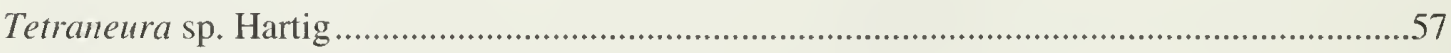

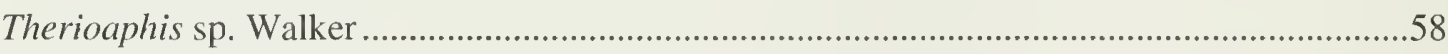

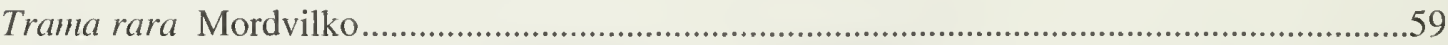

Uroleucon (Uromelan) taraxaci (Kaltenbach) ........dark dandelion aphid ...................................60 
Acyrthosiphon pisum (Harris)

pea aphid

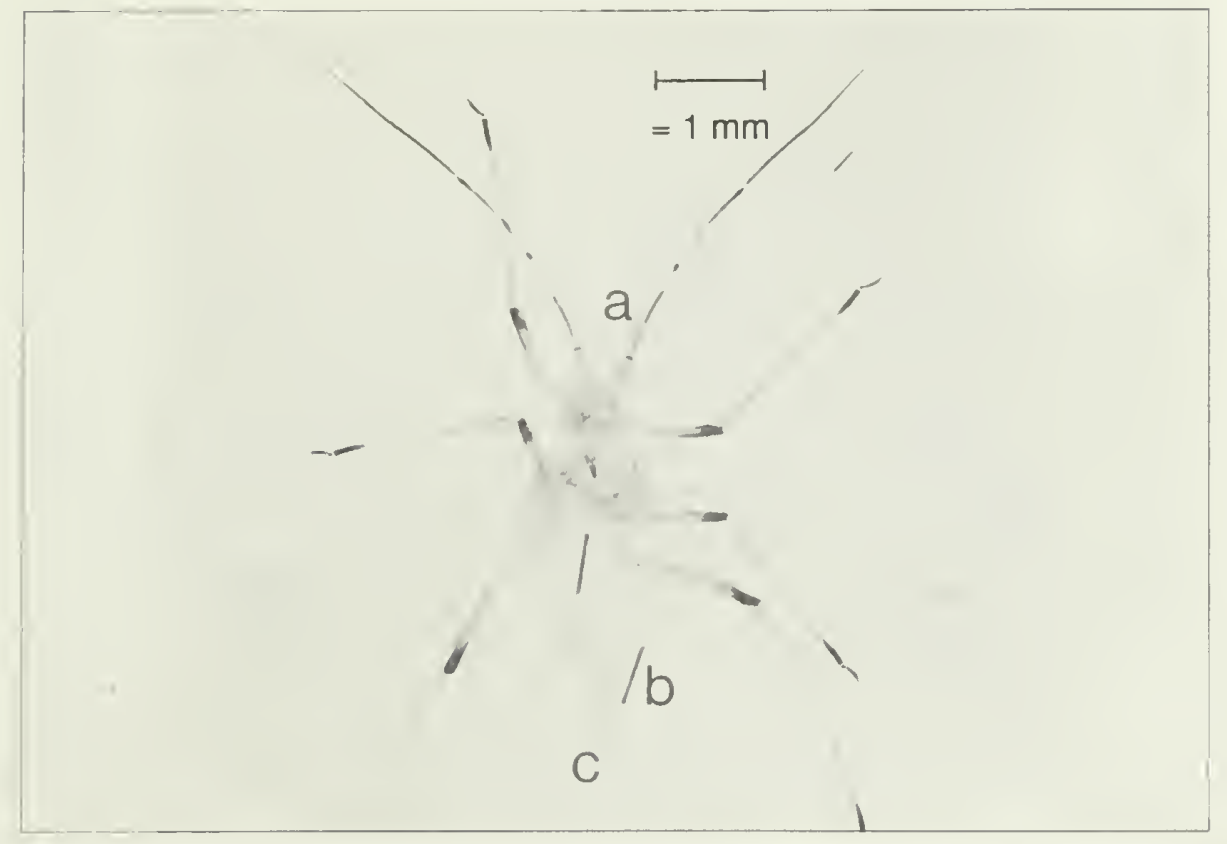

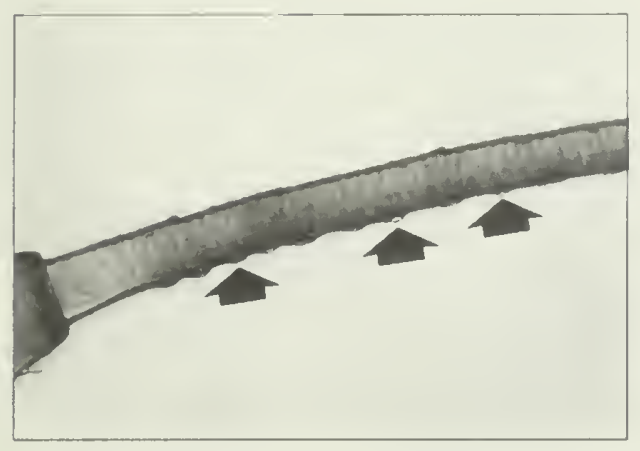

(a) sensoria

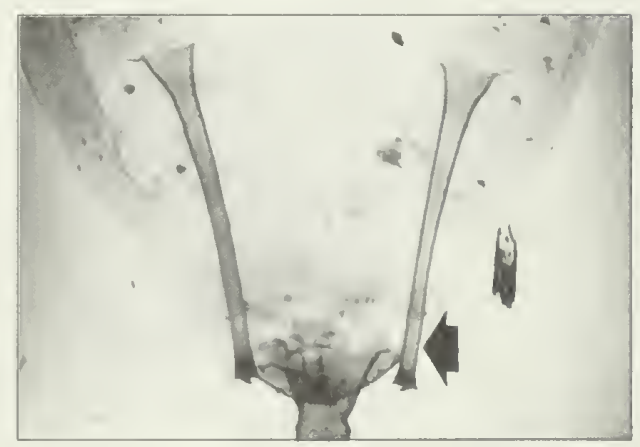

(b) siphunculus

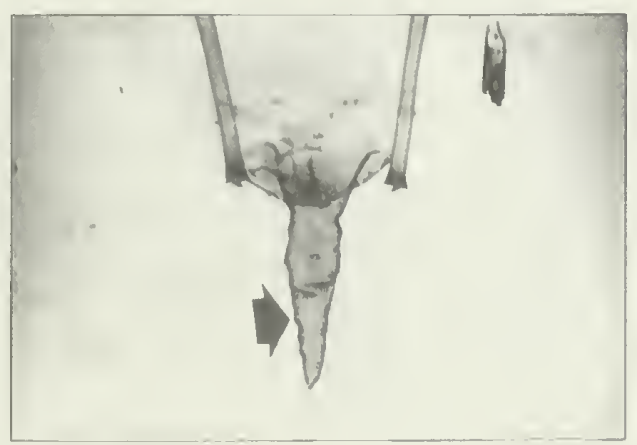

(c) coucla

Antenna slightly longer than body; antennal segment III with dark, narrow band at tip and with 12-21 sensoria; processus terminalis at most four times longer than base of antennal segment VI; siphunculus long. slender, tapering, and imbricated from base to blackish tip; cauda long and slender, more than half the length of siphunculus, and tapering to a point. References: Kono and Papp 1977. Medler and Ghosh 1969. 


\section{Amphorophora agathonica Hottes}

large American raspberry aphid

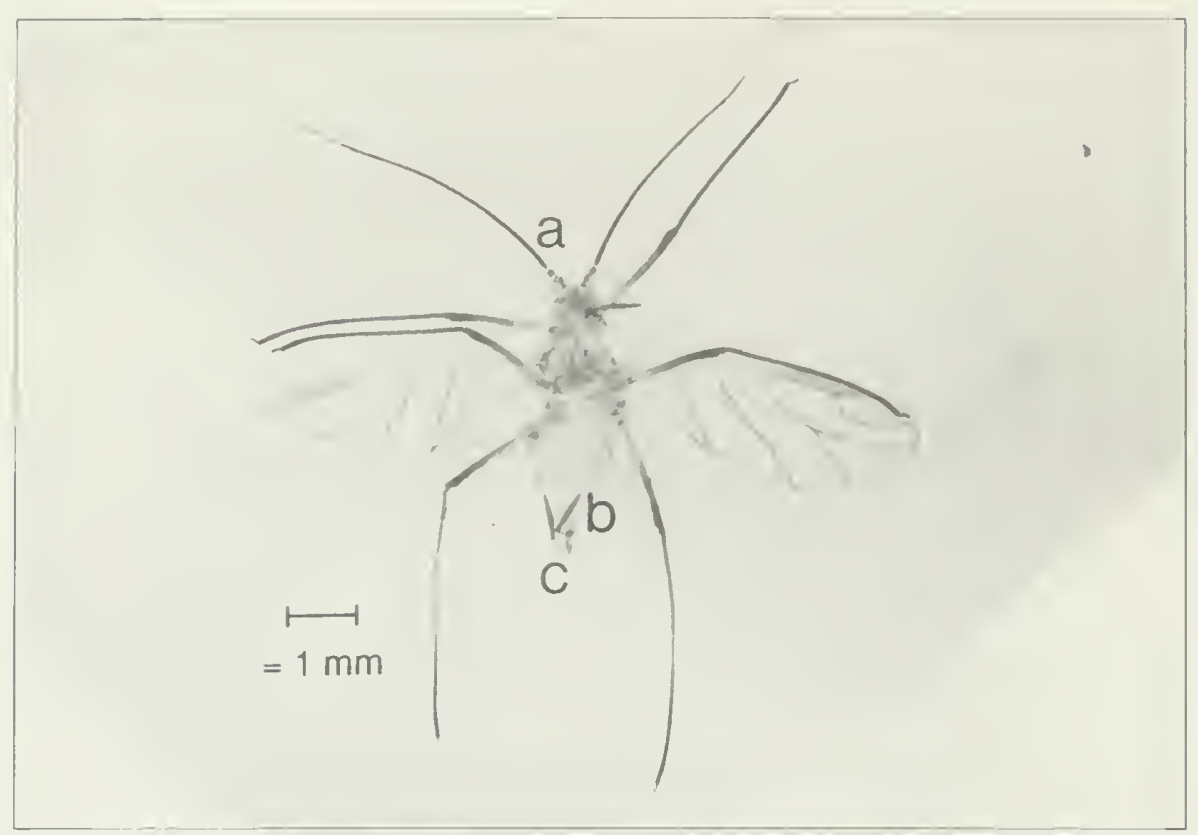

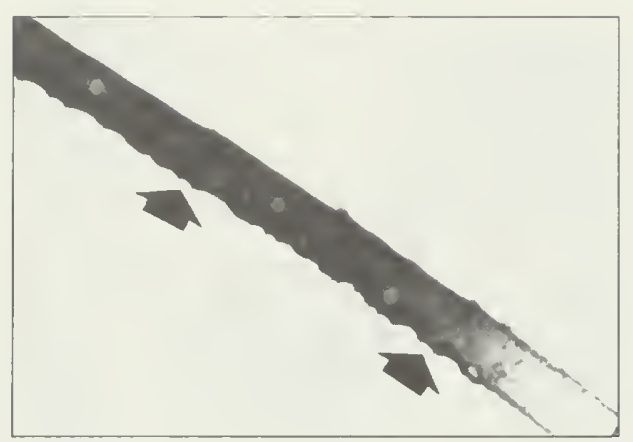

(a) sensoria

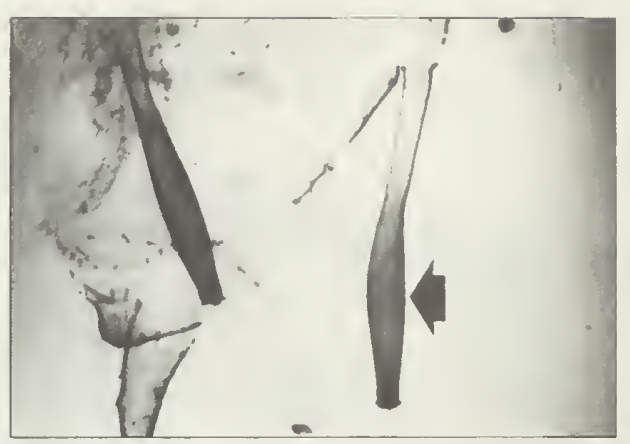

(b) siphunculus

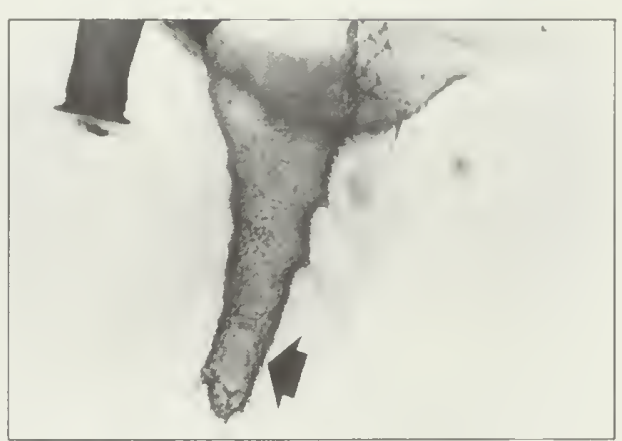

(c) cauda

Antennal segment III with at least 56 sensoria; antennal tubercles well developed; siphunculus long, swollen, not reticulated; cauda narrowly triangular; legs light dusky to pale. References: Foottit and Richards 1993, Palmer 1952. 


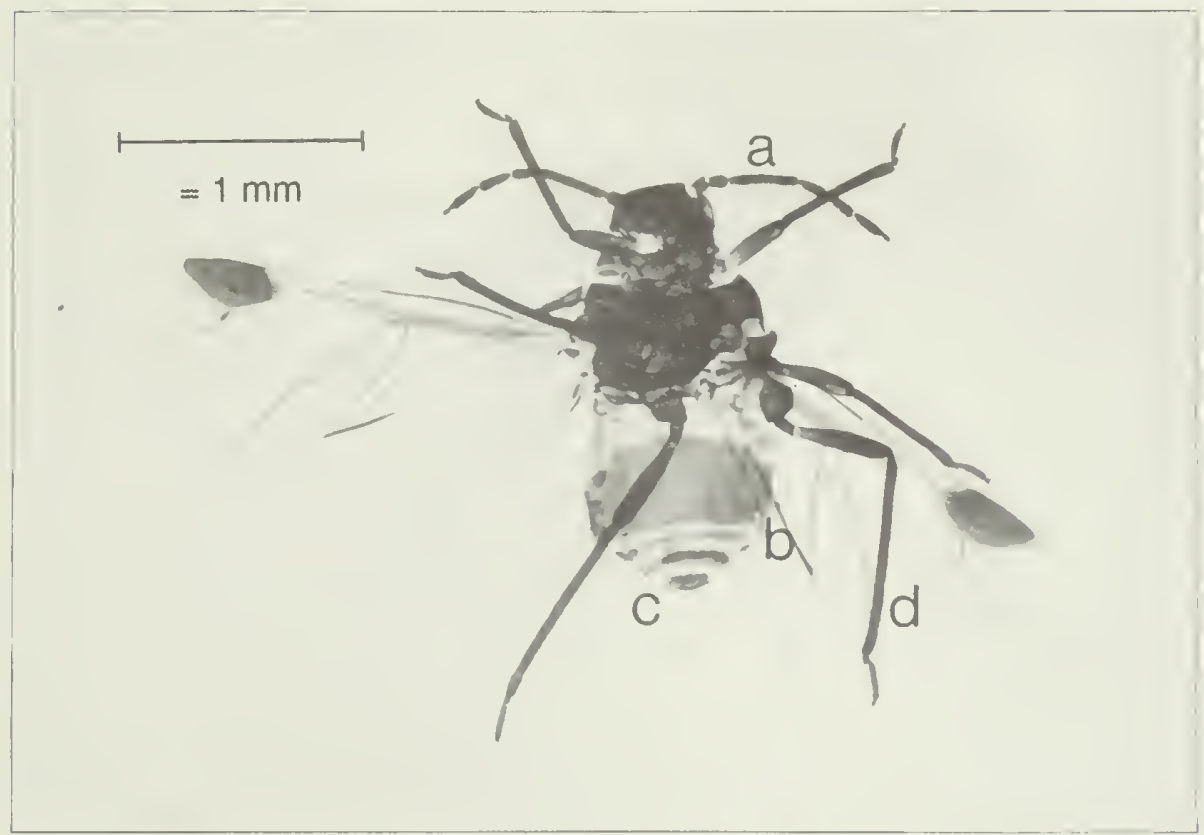

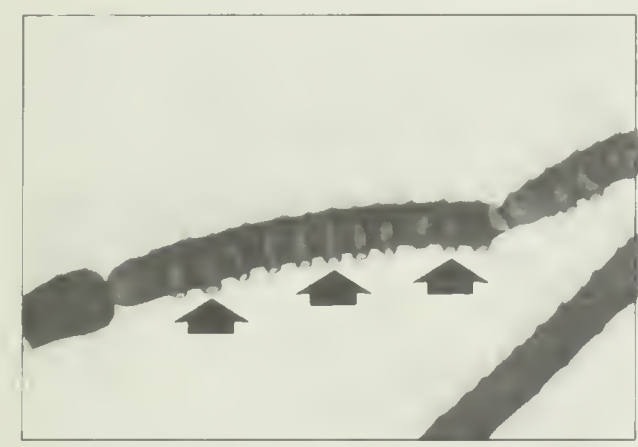

(a) sensoria

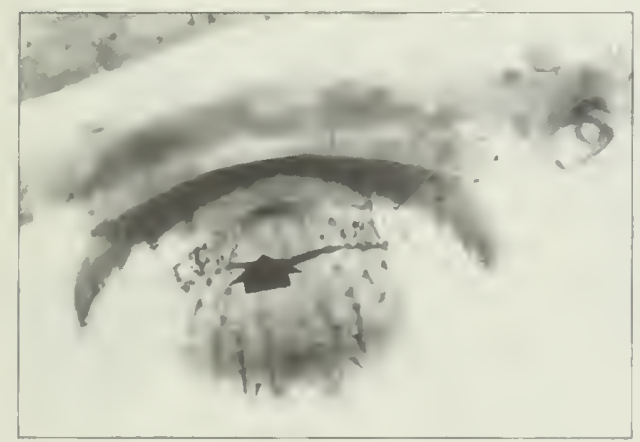

(c) cauda

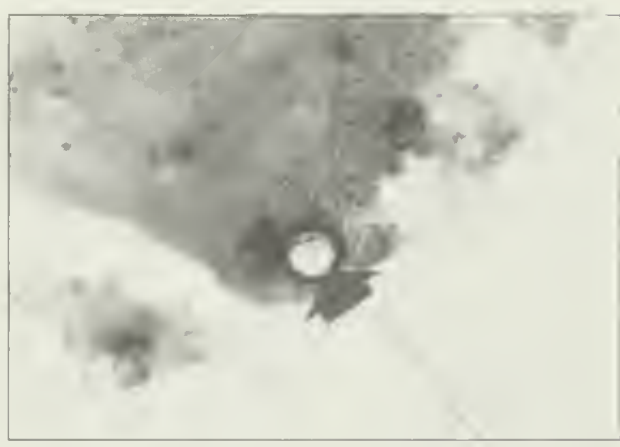

(b) siphunculus

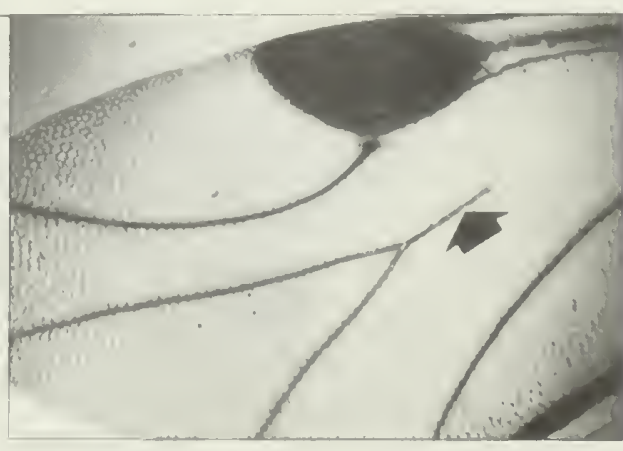

(d) I-forked media of fore wing

Antennal segment III with 9-17 sensoria; abdomen with large, black dorsal patch covering terga III-VI; siphuncular pore wide. on low, hairy cone; cauda and anal plate rounded; fore wing with very large black pterostigma and with 1-forked media. Reference: Heie 1980. 


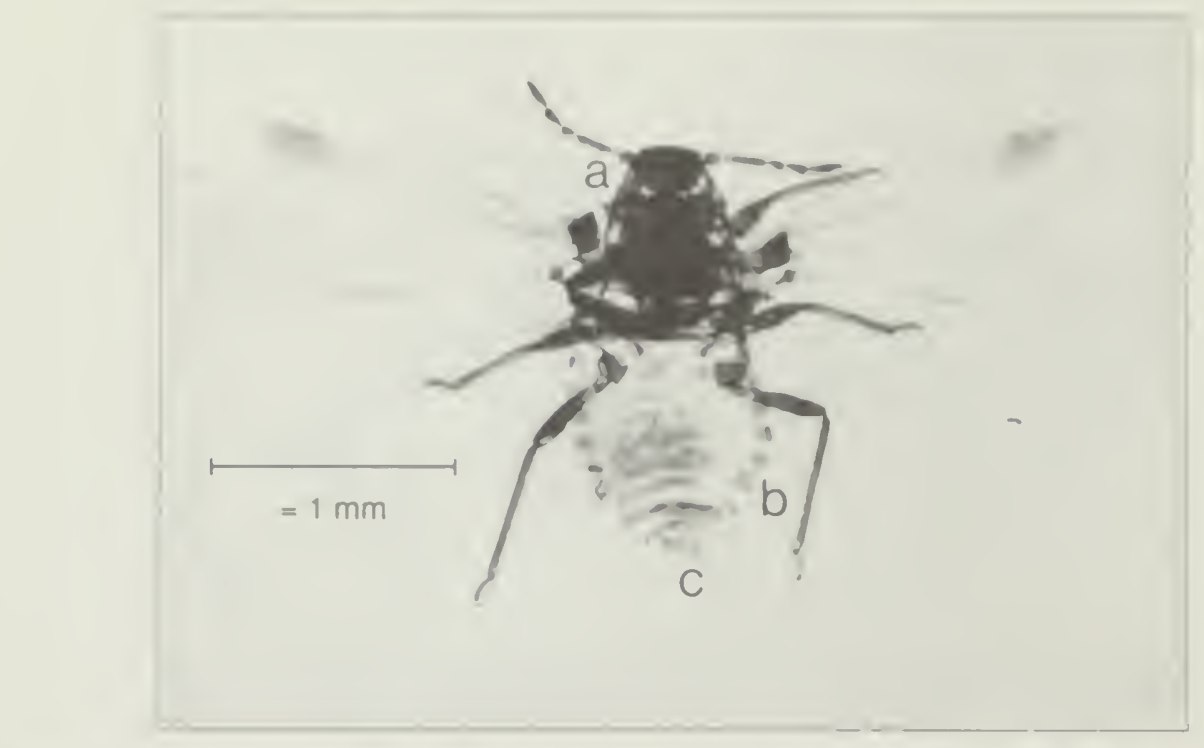

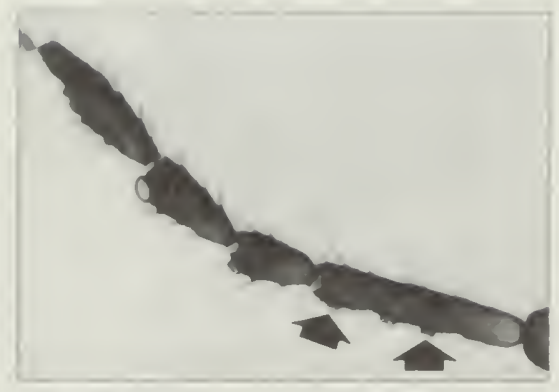

(a) sensoria

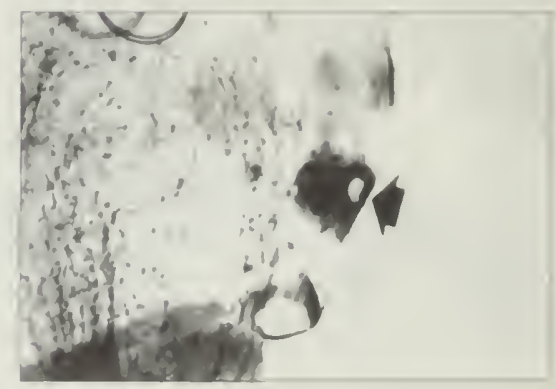

(b) siphunculus

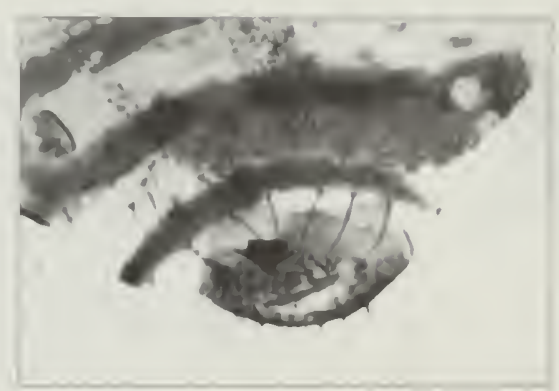

(c) coucla

Antennal segment III with 3 or 4 widely separatted sensoria: antemnal segment VI bearing short, thumb-like processus terminalis: head broadly rounded; body short and robust: abdomen with 5 distal dorsal stripes and with a row of 6 or 7 black spots on each side; siphunculus consisting of flanged edge on slightly raised base: cauda broadly rounded and broader than long: anal plate broadly rounded. merging into ahdomen: wings short and broad: wing veins not heavy: fore wing with 1-forked media. Reference: Wilson 1911. 


\section{Aphis sp. Linnaeus}

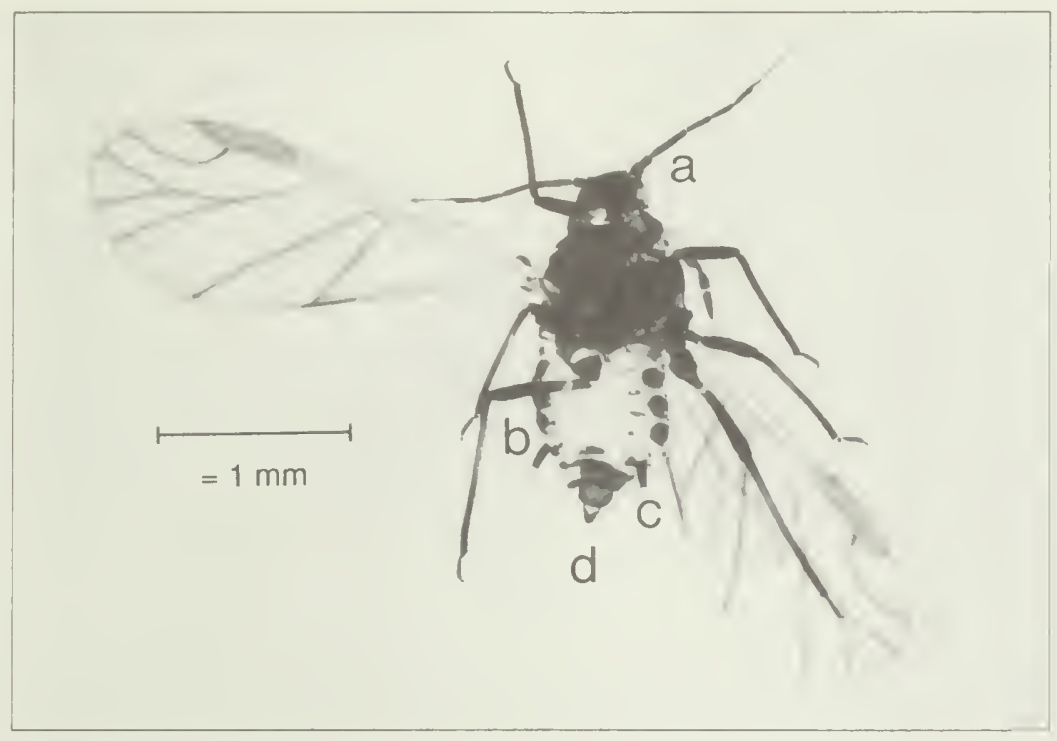

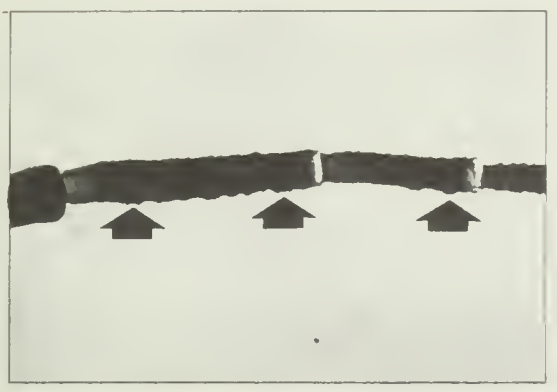

(a) sensoria

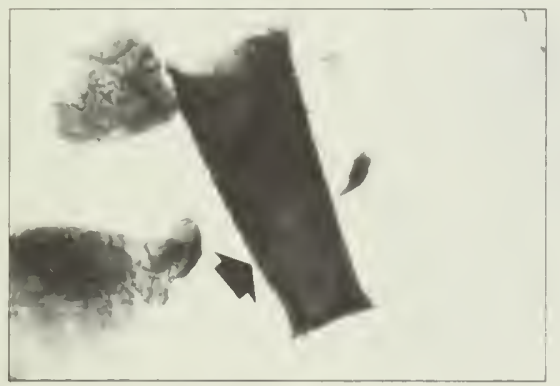

(c) siphunculus

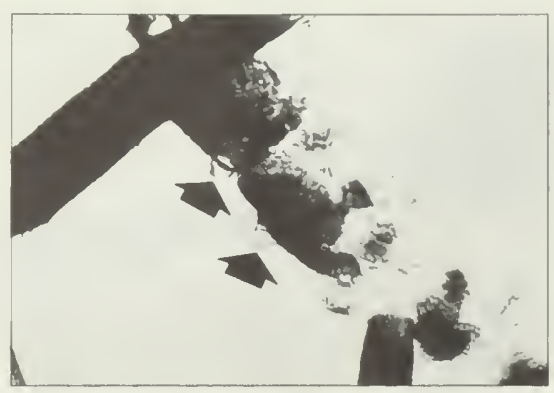

(b) lateral mbercles

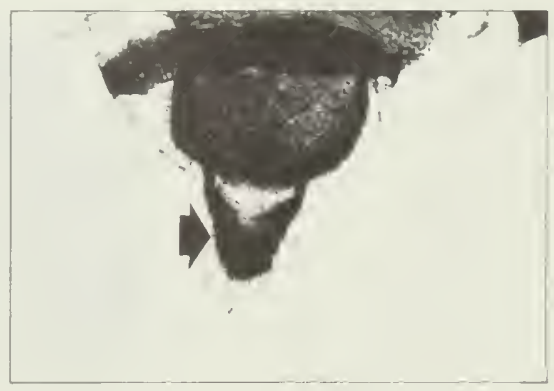

(d) cauda

Antenna 6- (rarely 5-) segmented; processus terminalis longer than base of VI; antennal segment III and sometimes IV and V with sensoria; antennal tubercles undeveloped; abdominal terga II and VII with lateral tubercles; other terga sometimes with lateral tubercles; abdomen with variable pigmentation but never with a dorsal patch; siphunculus short to medium length, cylindrical, with faint to distinct imbrications, and with slight flange; cauda elongate, slightly constricted near base; fore wing normally with 2-forked media. References: Foottit and Richards 1993, Heie 1986, Stroyan 1984. 


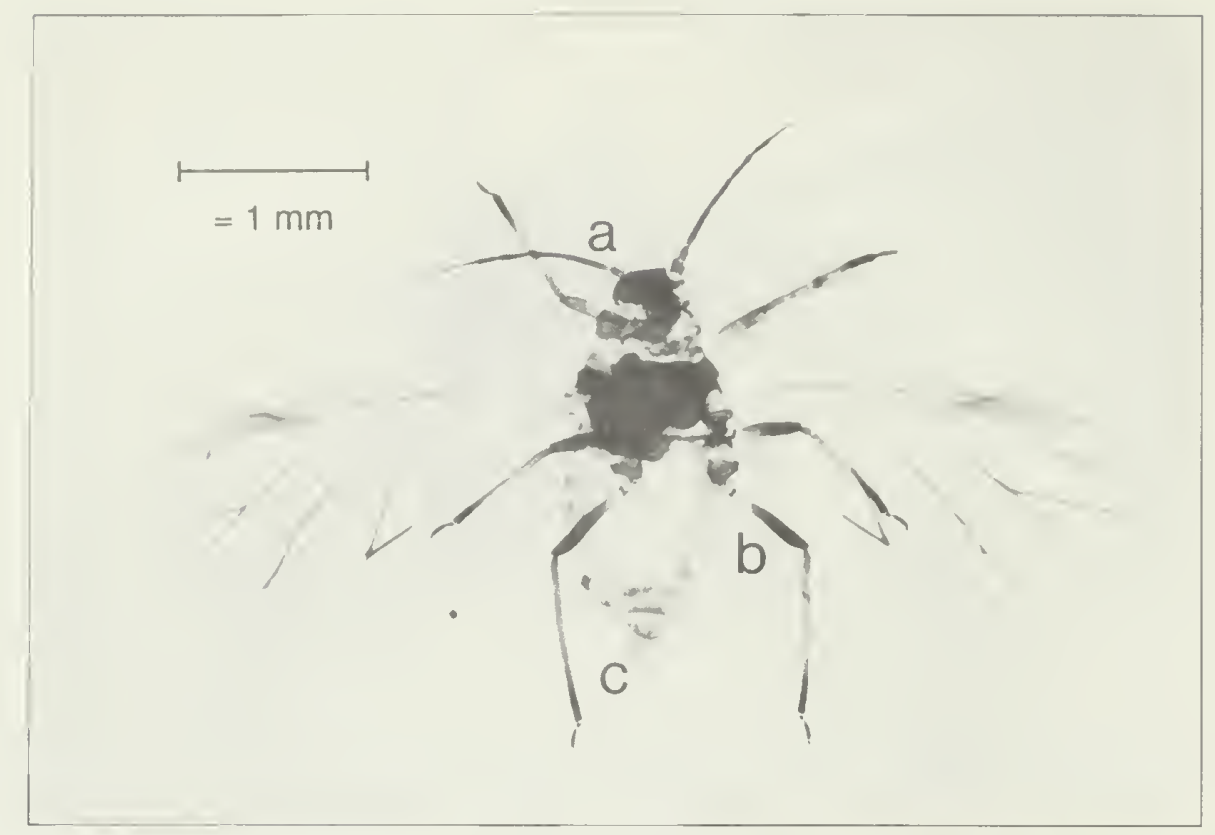

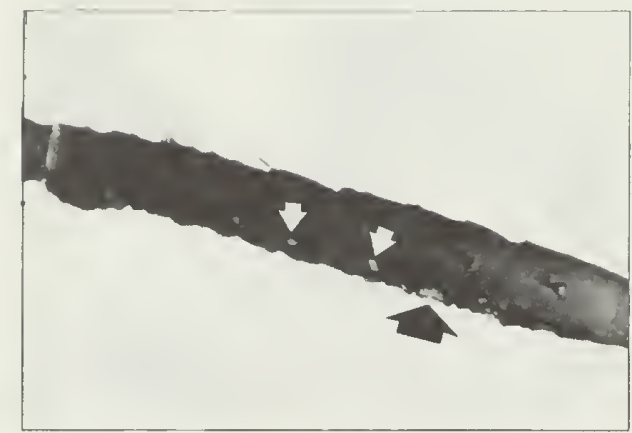

(a) sensoria

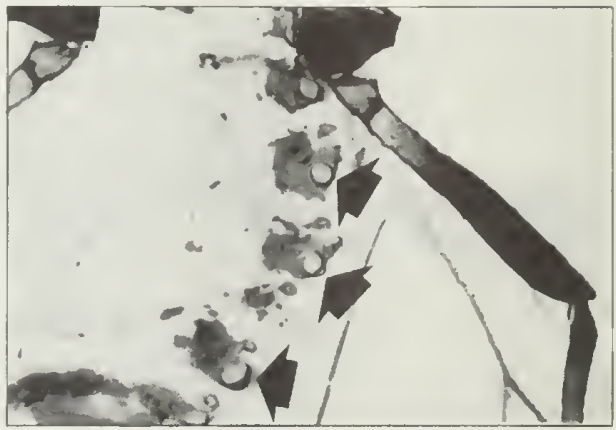

(b) lateral tubercles

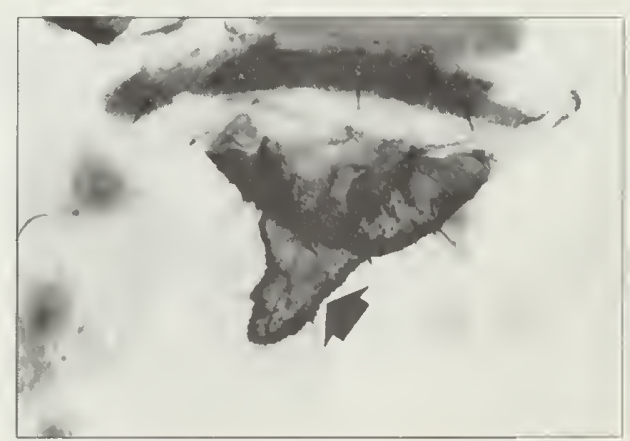

(c) cauda

Processus terminalis three times the length of base of antennal segment VI; prothorax and all abdominal segments with lateral tubercles; abdominal tergum I with broken dashes in middle; abdominal terga I-VI with dusky lateral areas; siphunculus absent; cauda tapering or parallel-sided. slightly constricted at middle. References: Palmer 1952, Robinson 1964. 


\section{Aulacorthum solani (Kaltenbach)}

foxglove aphid

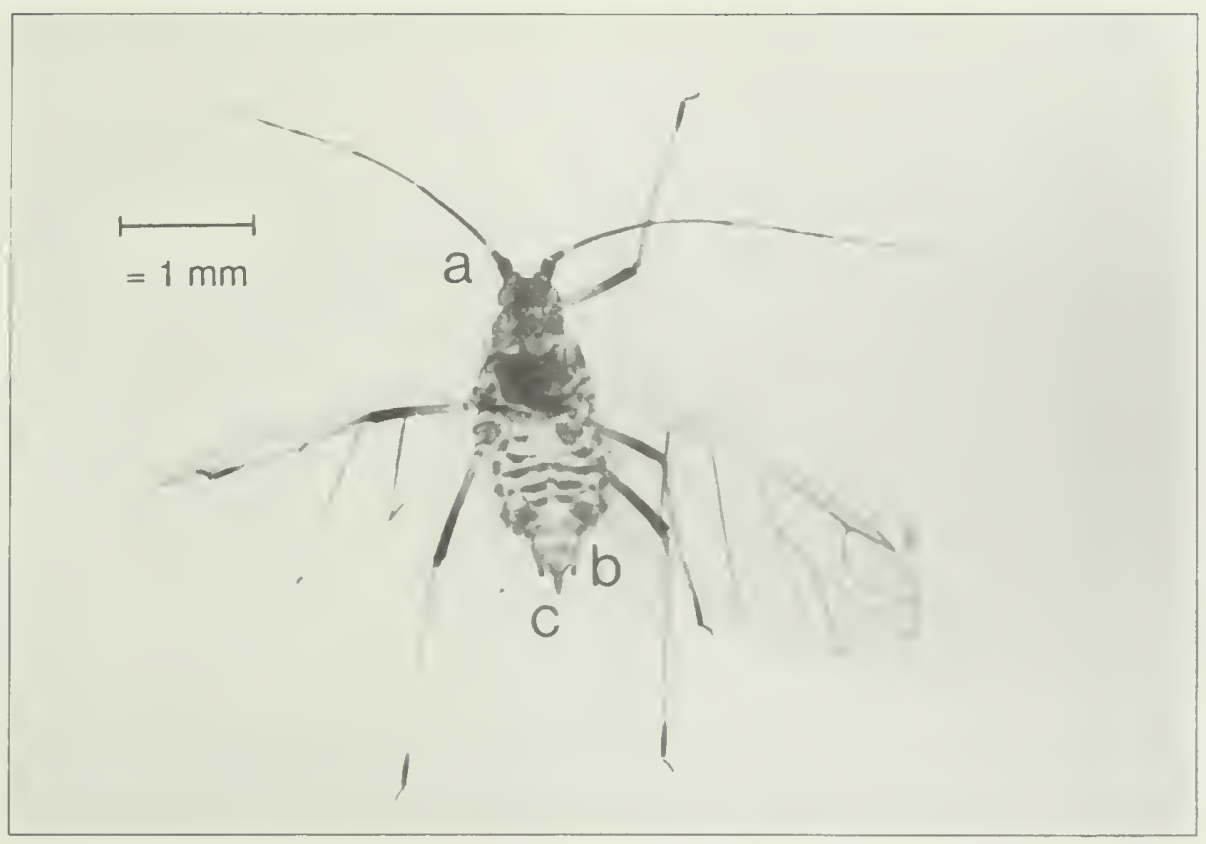

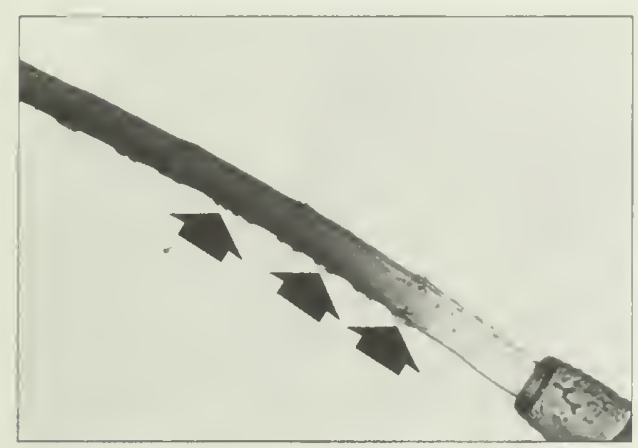

(a) sensoria

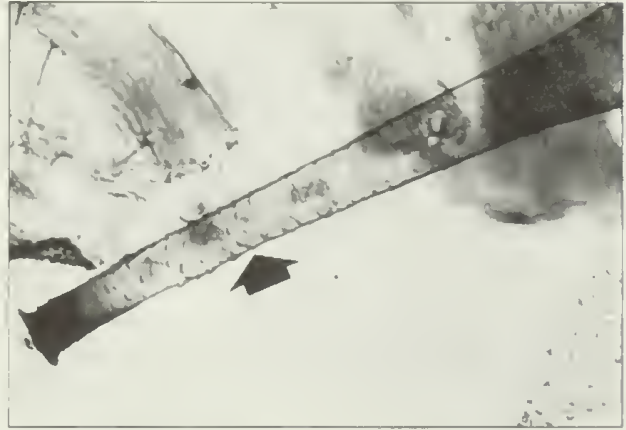

(b) siphunculus

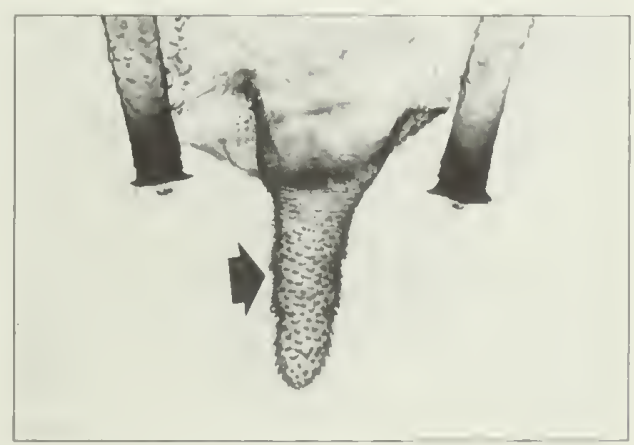

(c) cauda

Antennal segments dark; antennal segment II and bases of antennal segments III-V pale; abdomen with variable pattern of dorsal transverse dark bars: siphunculus long, pale, slender, tapering, imbricated from base to black tip, and at least twice as long as cauda. References: Blackman and Eastop 1984, Kono and Papp 1977. 
Brachycaudus (Acaudus) cardui (Linnaeus)

thistle aphid

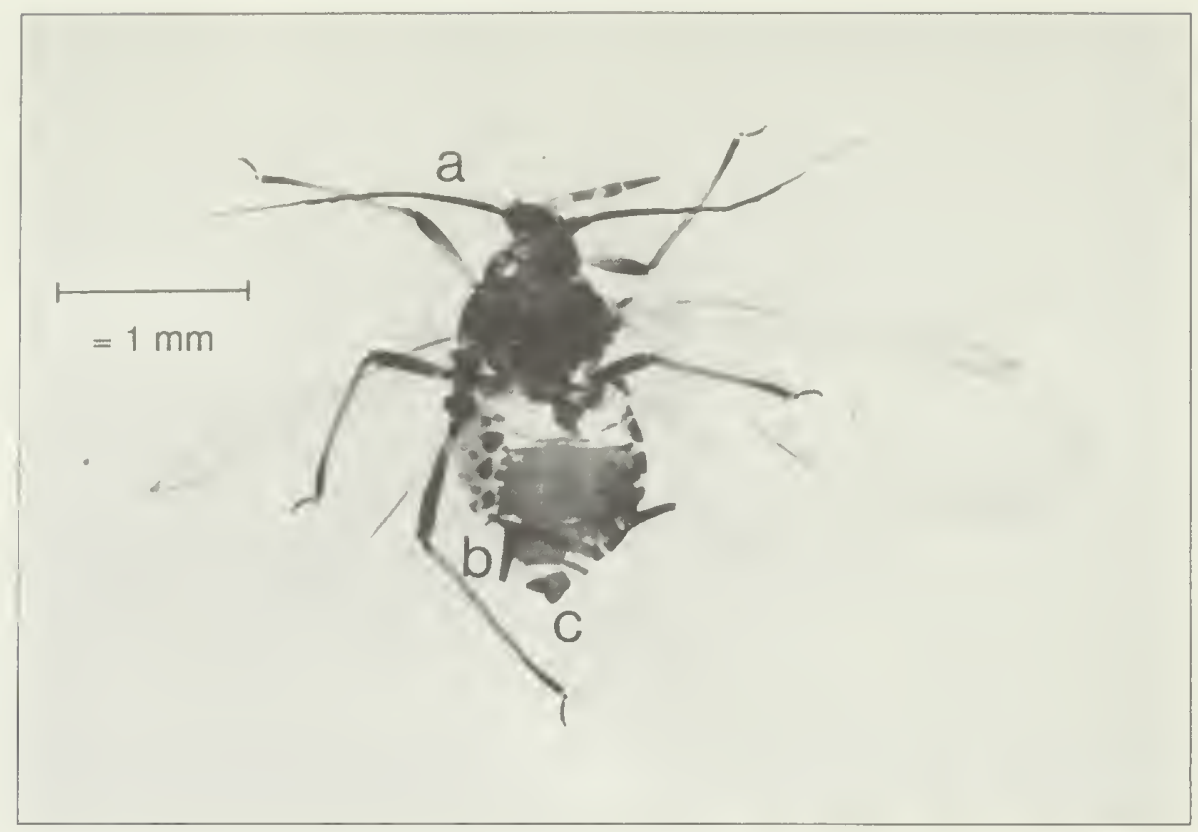

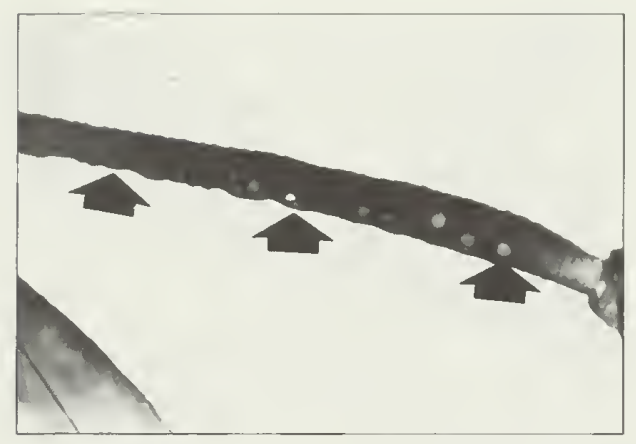

(a) sensoria

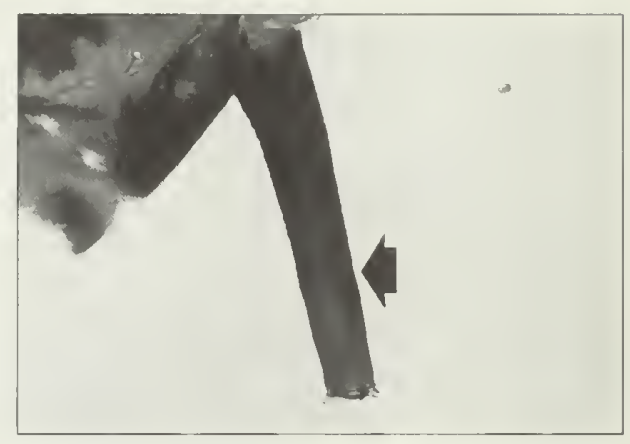

(b) siphunculus

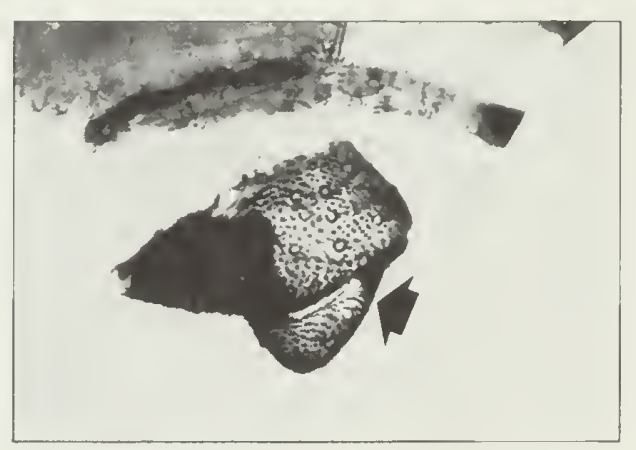

(c) canda

Abdomen with large dorsal patch and bands, the patch extending over most of abdomen; prothorax and abdominal terga with lateral tubercles; siphunculus tapering, faintly imbricated, with slight flange; cauda tapering, broader than long. References: Palmer 1952, Taylor et al. 1984. 
Brachycaudus helichrysi (Kaltenbach)

leaf-curling plum aphid

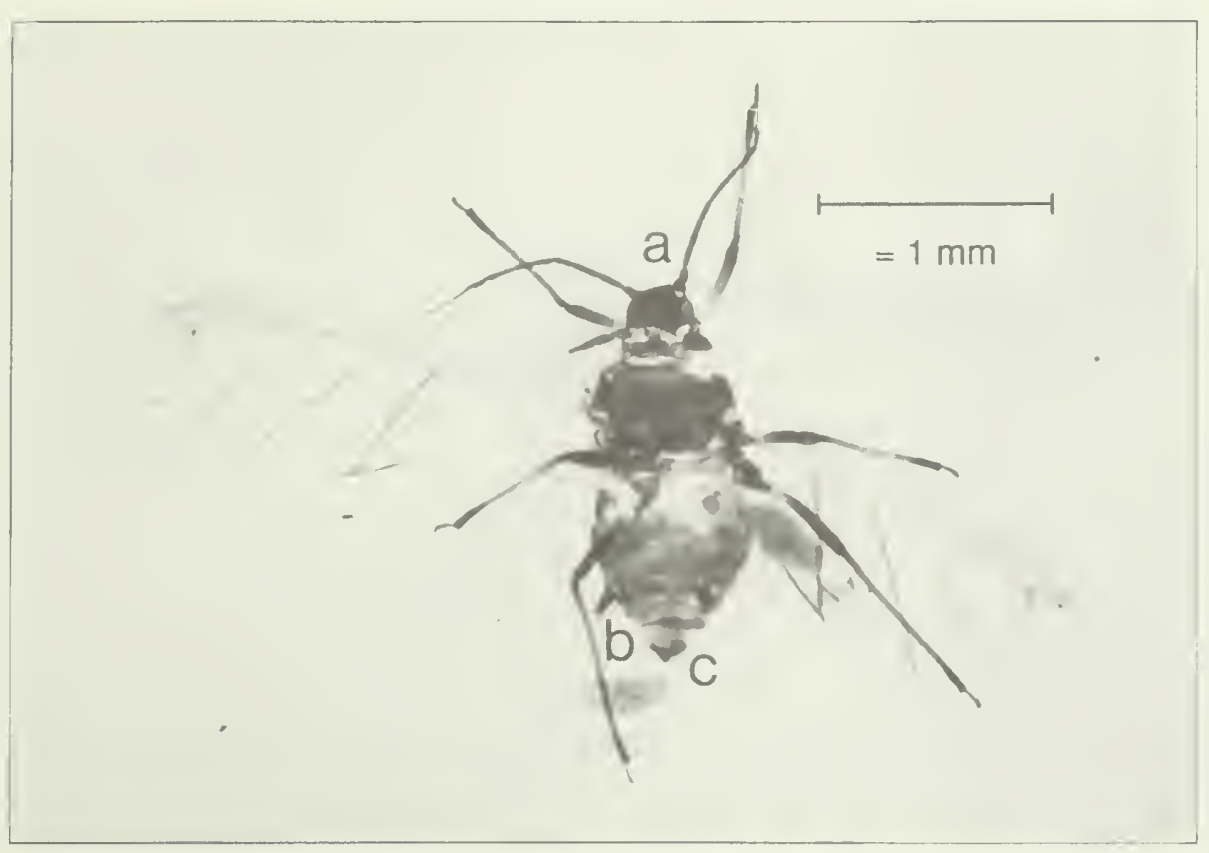

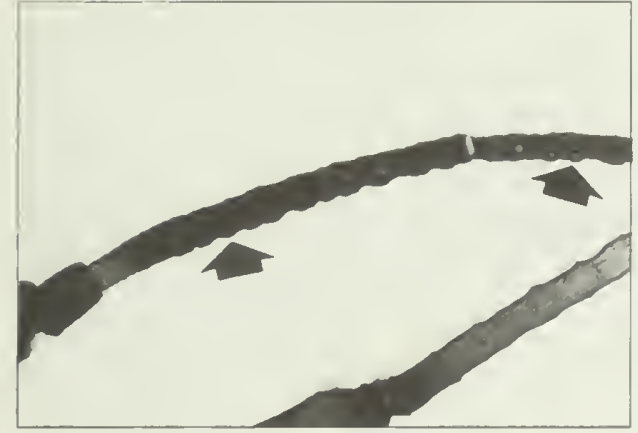

(a) sensoria

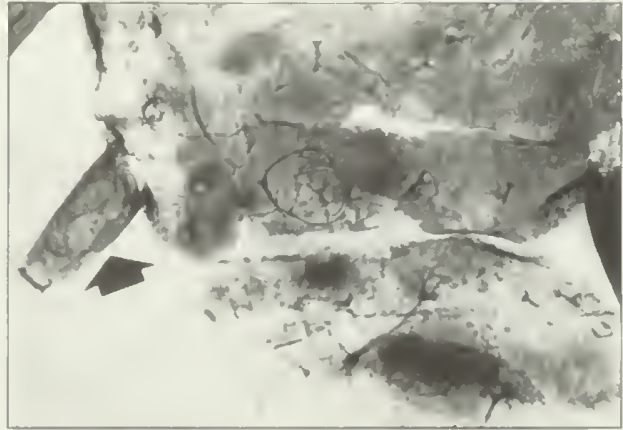

(b) siphunculus

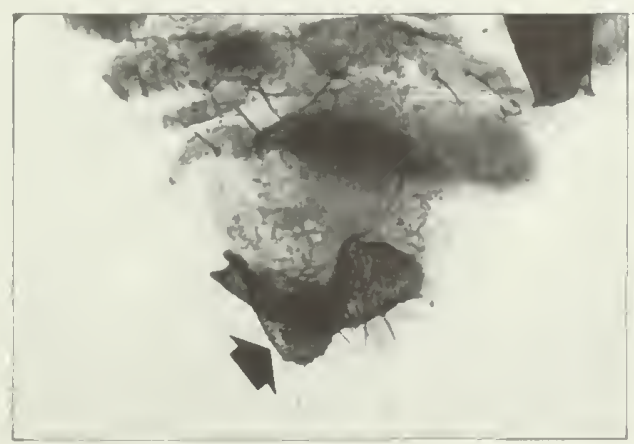

(c) cauda

Antennal segments III and IV with unevenly scattered sensoria; abdomen with large, black dorsal patch that covers most of area, from tergum III to apex: siphunculus cylindrical, smooth to slightly imbricated, tapering, with smaller. black patch at base: cauda semicircular. not longer than broad at base. References: Cottier 1953, Martin 1983. 
Brevicoryne brassicae (Linnaeus)

cabbage aphid

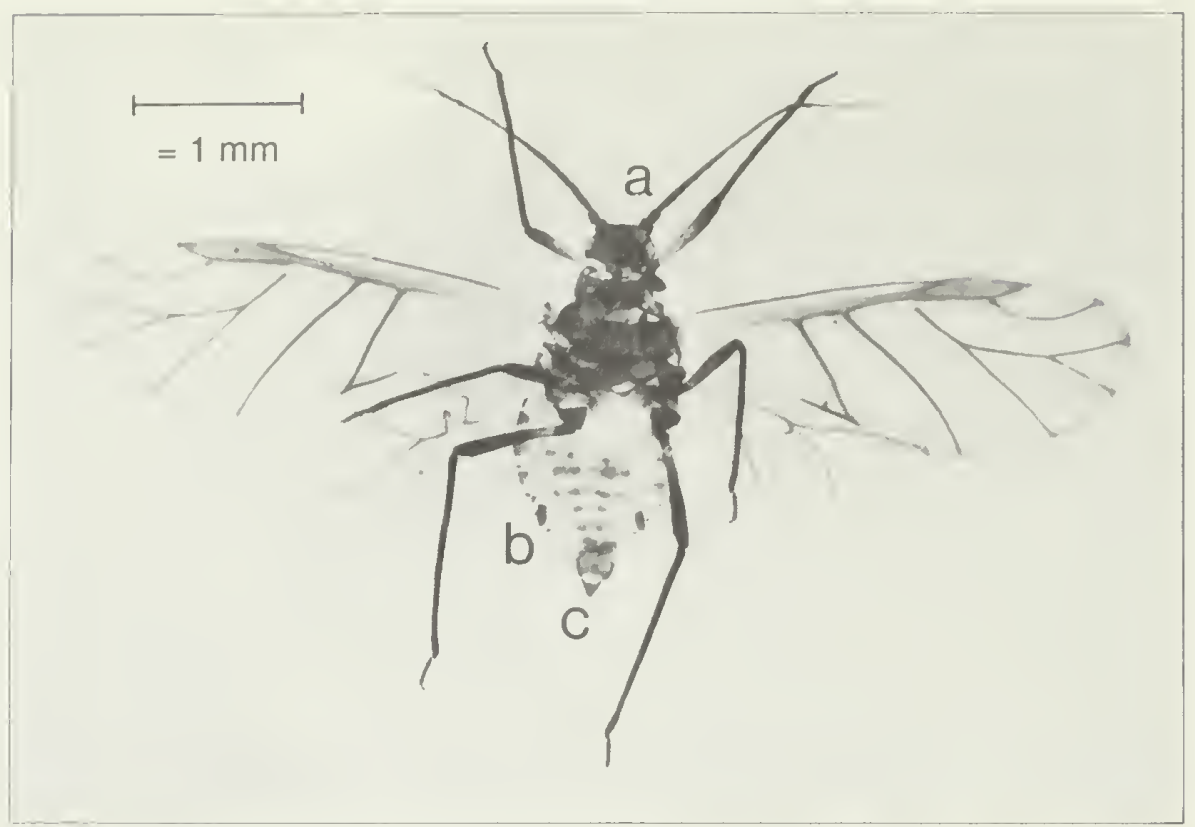

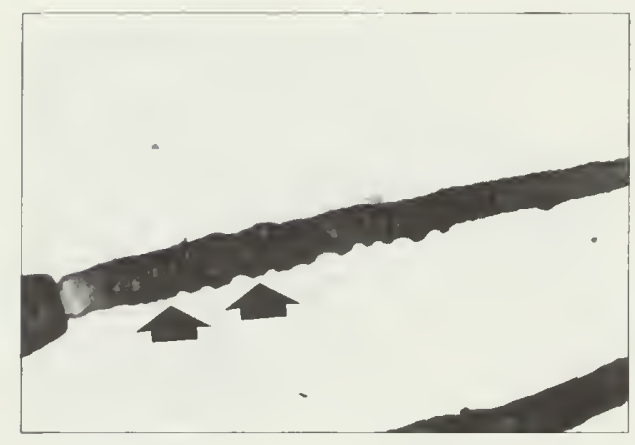

(a) sensoria

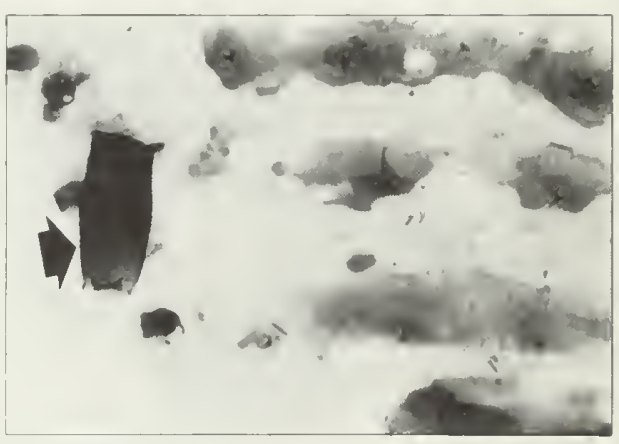

(b) siphunculus

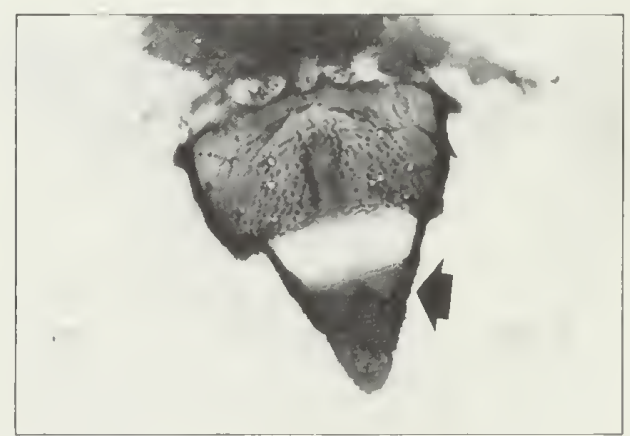

(c) canda

Antennal segment III with approximately 50 sensoria that have distinct margins; abdomen with stripes that are broken in middle; siphunculus short, barrel-shaped, medium-pigmented, with small flange; cauda triangular; wing veins dark. References: Palmer 1952, Taylor et al. 1984. 


\section{Calaphis betulaecolens (Fitch)}

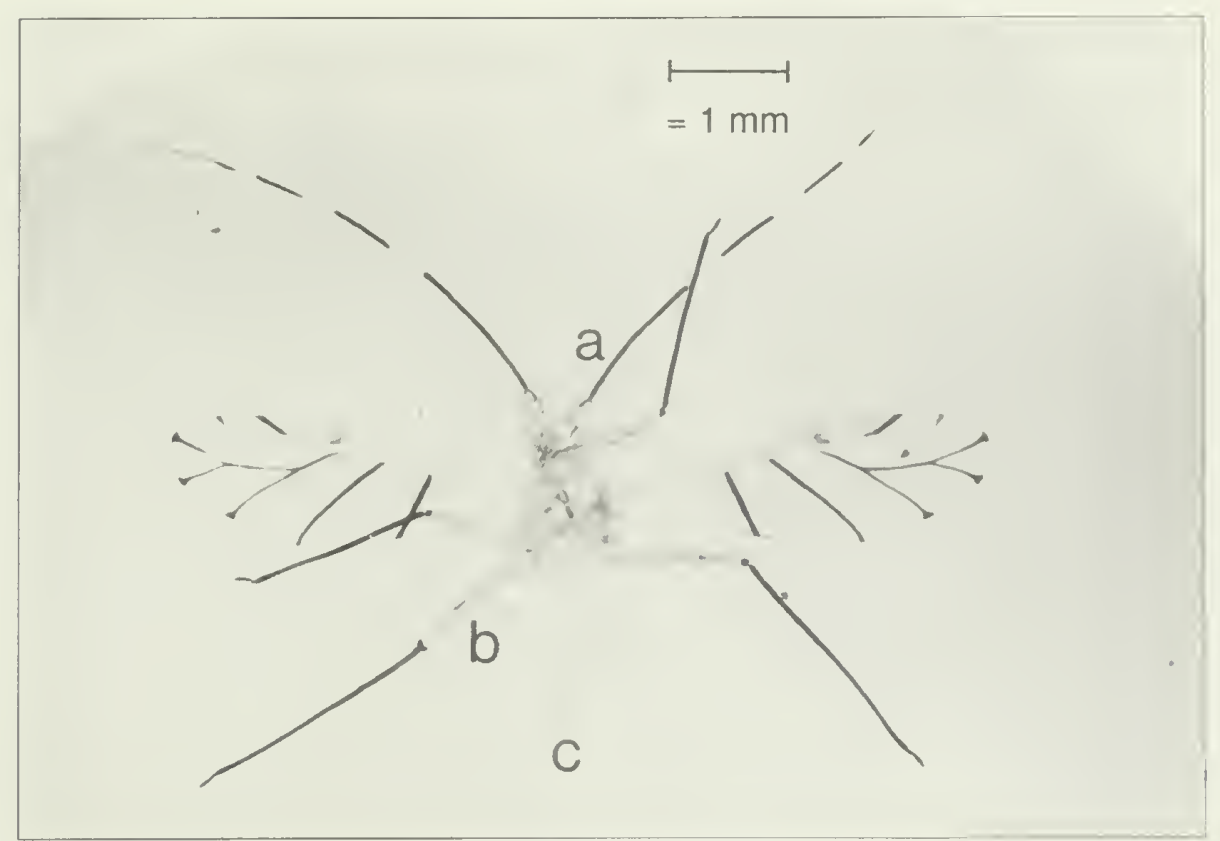

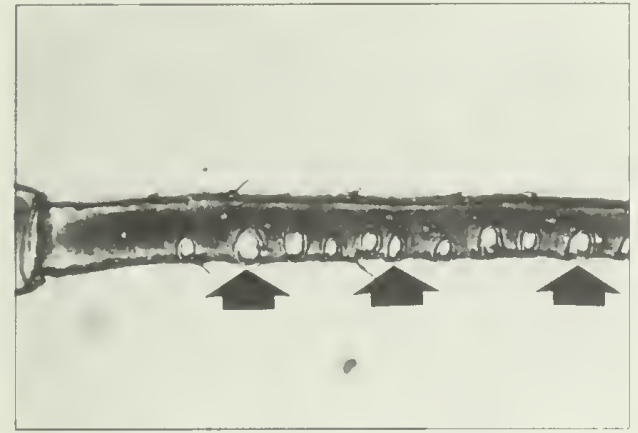

(a) sensoria

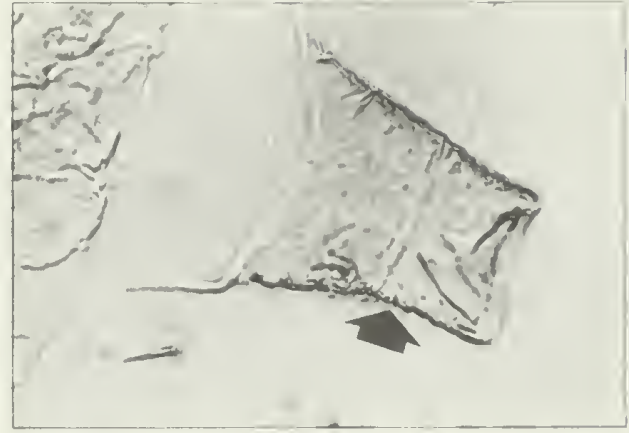

(b) siphunculus

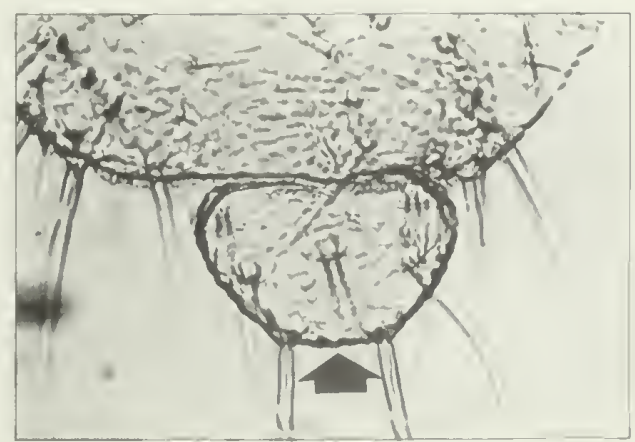

(c) cauda

Antennal segments 1 and $I 1$ infuscated at inner margin; antennal segment III dark, with black tip, and with 12-20 elliptical sensoria that are found at base of segment; antennal segments IV and V palc at base, but black distally; antennal segment VI infuscated, with black spot, but pale at base; antennal tubercles well developed; siphunculus short, cylindrical, flared apically, without flange: cauda slightly constricted at apex: anal plate bilobed: fore wing with stigma darkened at inner margin, with strong oblique veins, and with heavy cubital veins: radial sector faint at origin; radial sector and branches of media with dark spots at tips. Reference: Quednau 1971. 
Capitophorus elaeagni (del Guercio)

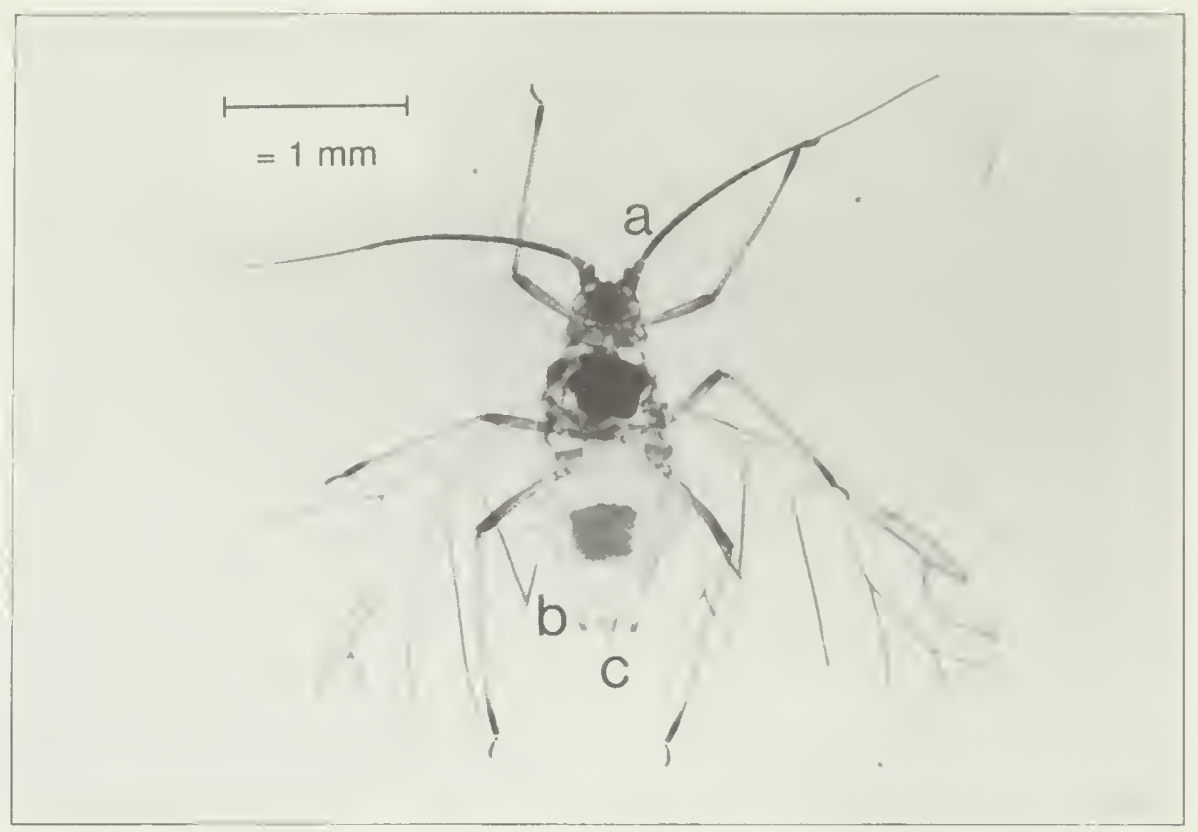

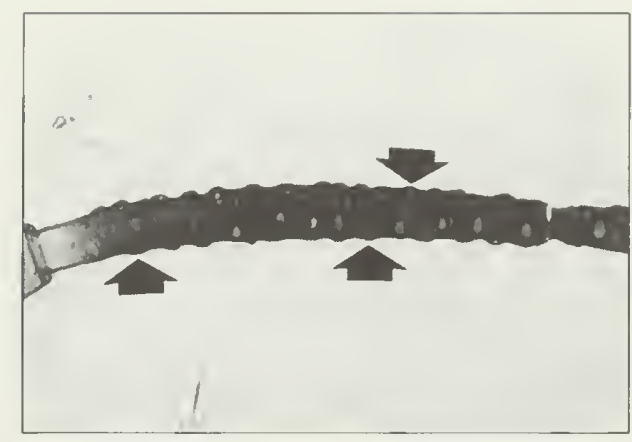

(a) sensoria

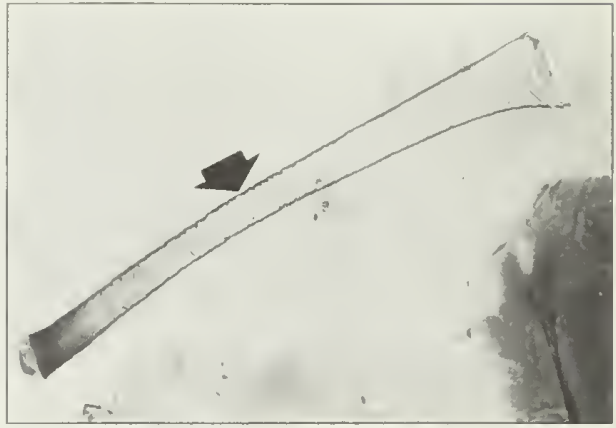

(b) siphunculus

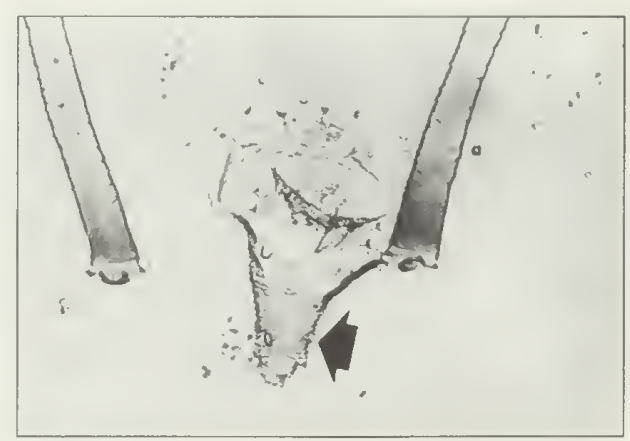

(c) cauda

Antennal segment III proximally pale, with 30-50 tubercle-shaped sensoria; antennal tubercles well developed; abdomen with almost rectangular, solid, black dorsal patch; siphunculus very long, with dusky apex; cauda short. References: Blackman and Eastop 1984, Palmer 1952, Taylor et al. 1984. 


\section{Capitophorus hippophaes (Walker)}

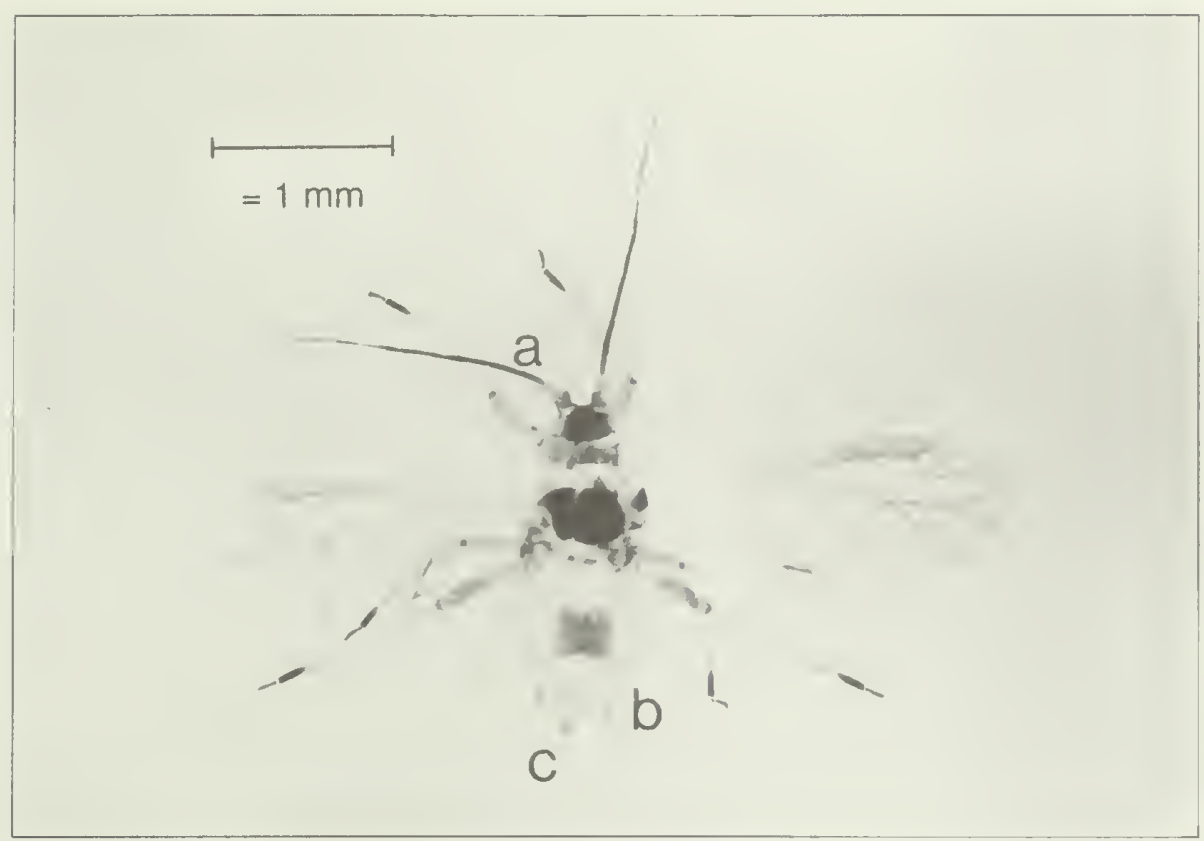

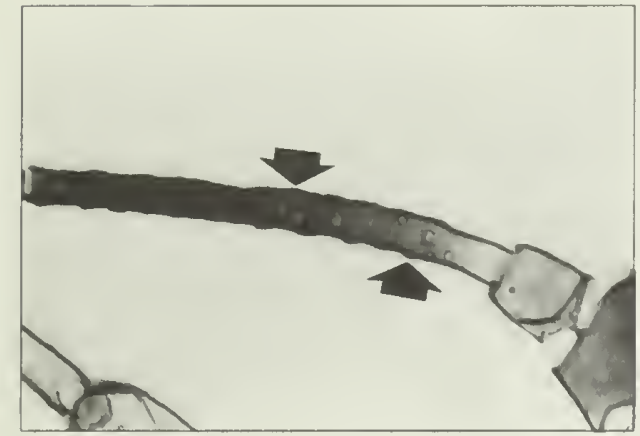

(a) sensoria

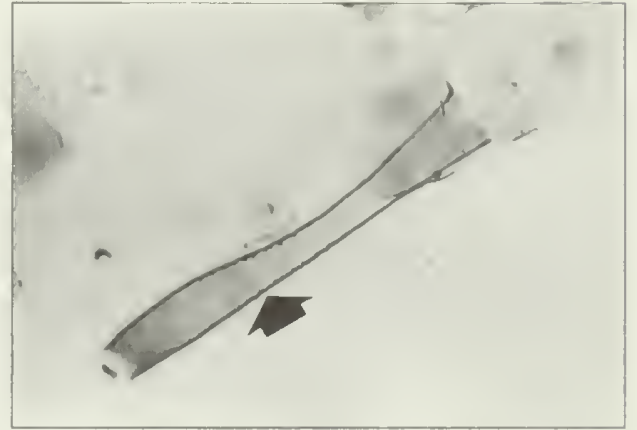

(b) siphunculus

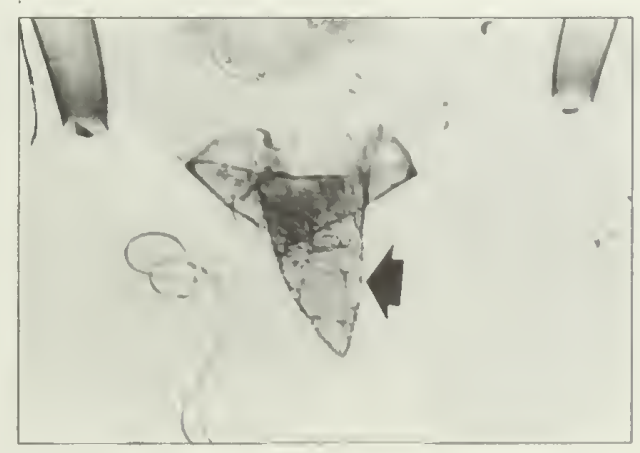

(c) cauda

Processus terminalis long; abdomen pale, with narrow dorsal dash on tergum II and dark dorsal patch on terga III, IV, and V, the patch sometimes broken into stripes; siphunculus swollen, medium-pigmented, with pale base; cauda pale. pointed, less than half the length of siphunculus. References: Palmer 1952. Taylor et al. 1984. 


\section{Cavariella aegopodii (Scopoli)}

willow-carrot aphid

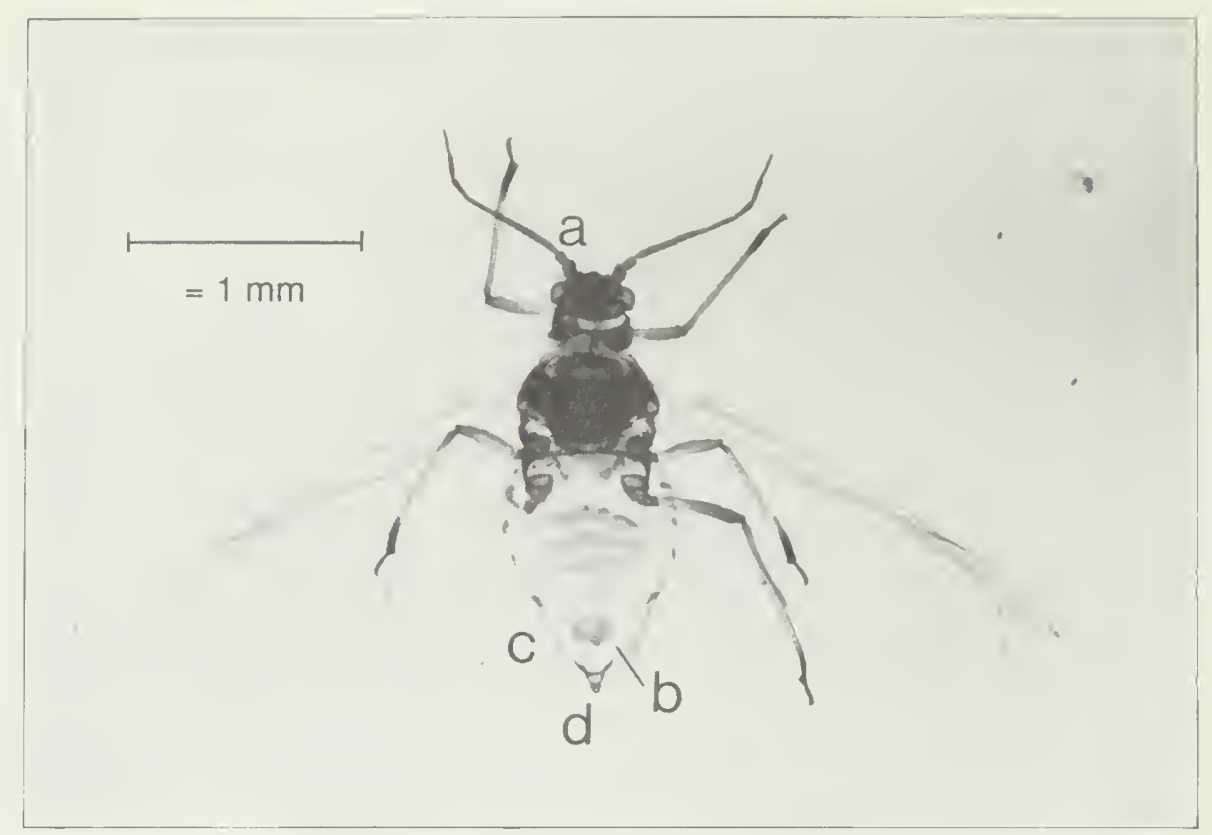

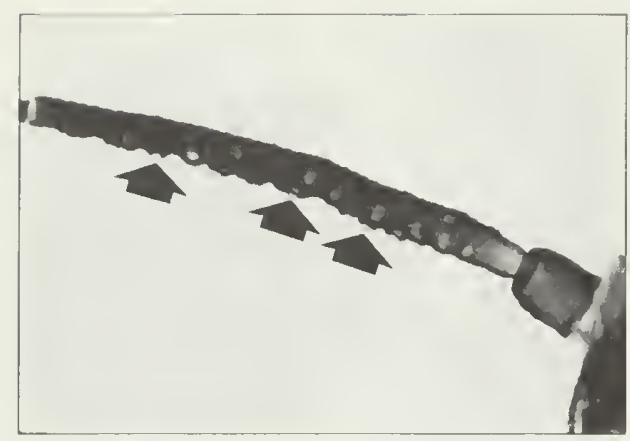

(a) sensoria

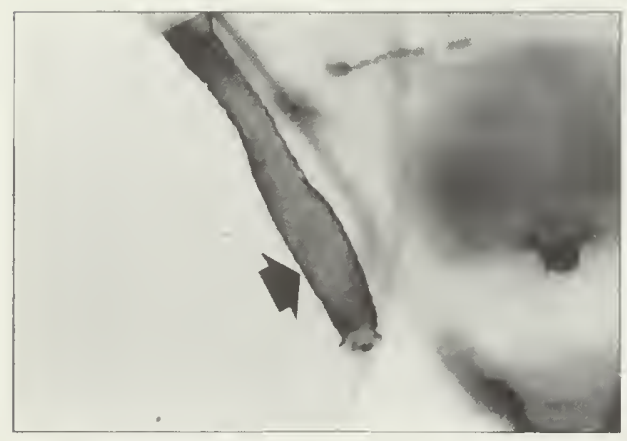

(c) siphunculus

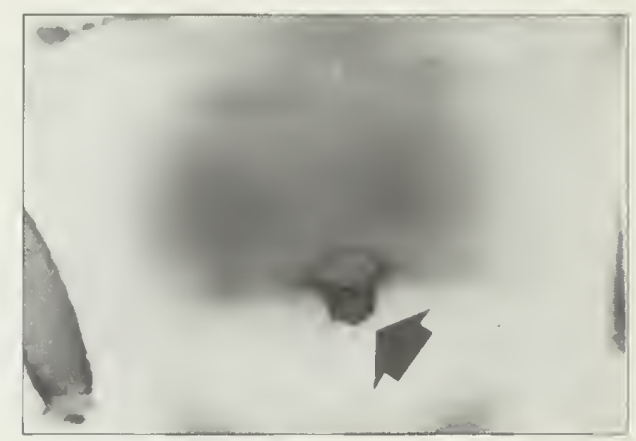

(b) dorsal papilla

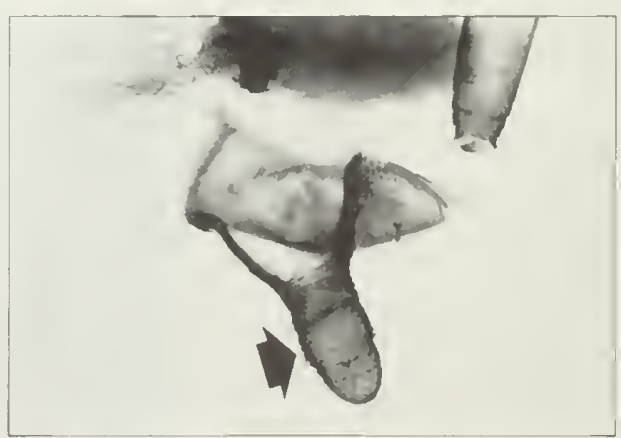

(c) cauda

Antennal segment III with tubercle-shaped sensoria; processus terminalis short, not noticeably longer than base of antennal segment VI; abdomen pale, with dark lateral areas and dark dorsal bands that begin on tergum III and coalesce on terga III, IV, and V; tergum VIII with a short, blunt dorsal papilla that bears 2 setae at tip; siphunculus clavate, faintly imbricated distally, with flange; cauda tapering. Reference: Palmer 1952. 


\section{Chaitophorus nigrae Oestlund}

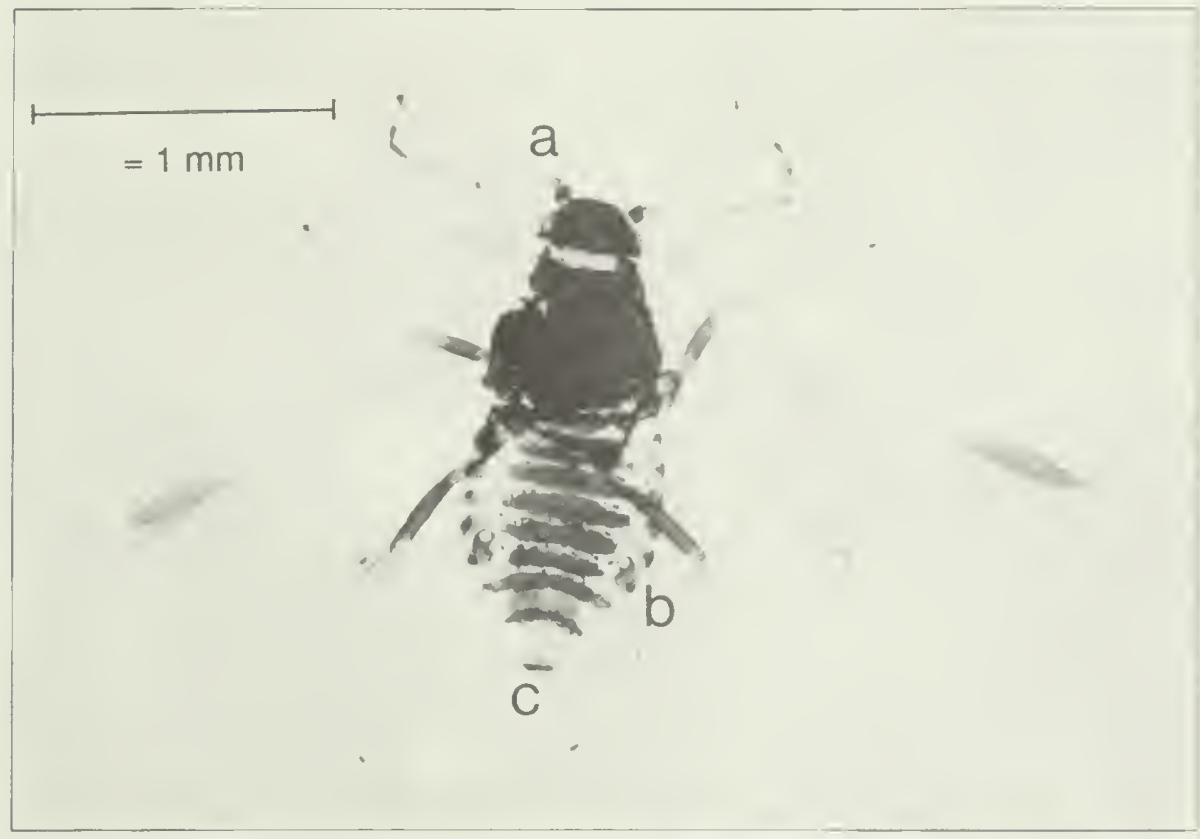

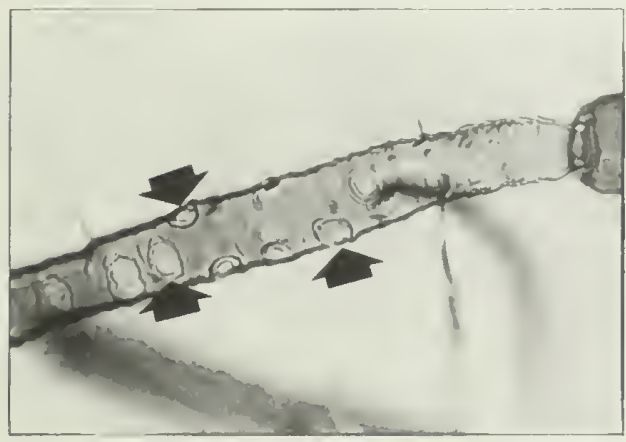

(a) sensoria

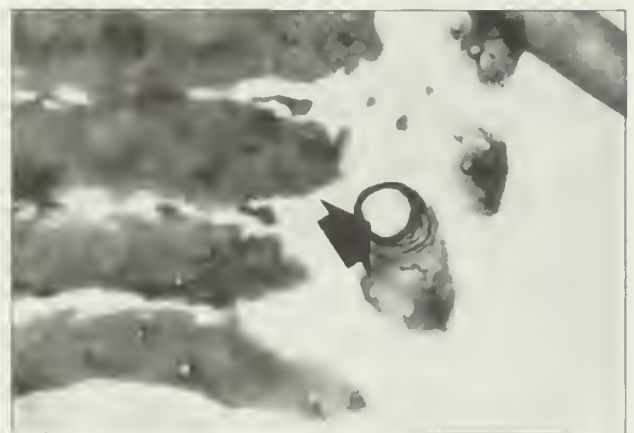

(b) siphunculus

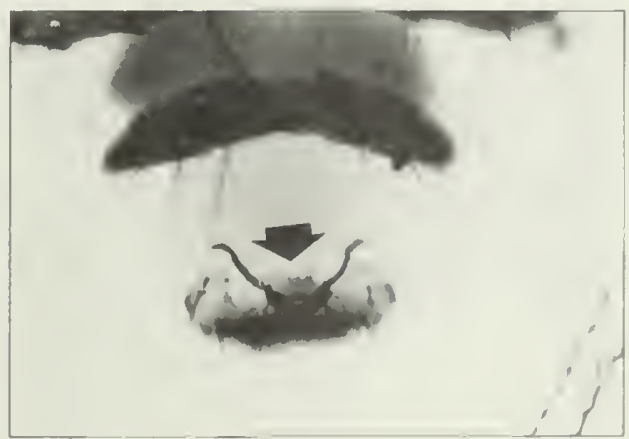

(c) cauda

Abdomen with brown lateral sclerites; abdominal terga cach with a transverse. brown bar that is partly fused on terga I-VI to form a single patch: siphunculus reticulated, about as long as antennal segment I; cauda knobbed or tongueshaped, with parallel or slightly diverging margins. Reference: Richards 1972. 


\section{Chaitophorus populicola Thomas}

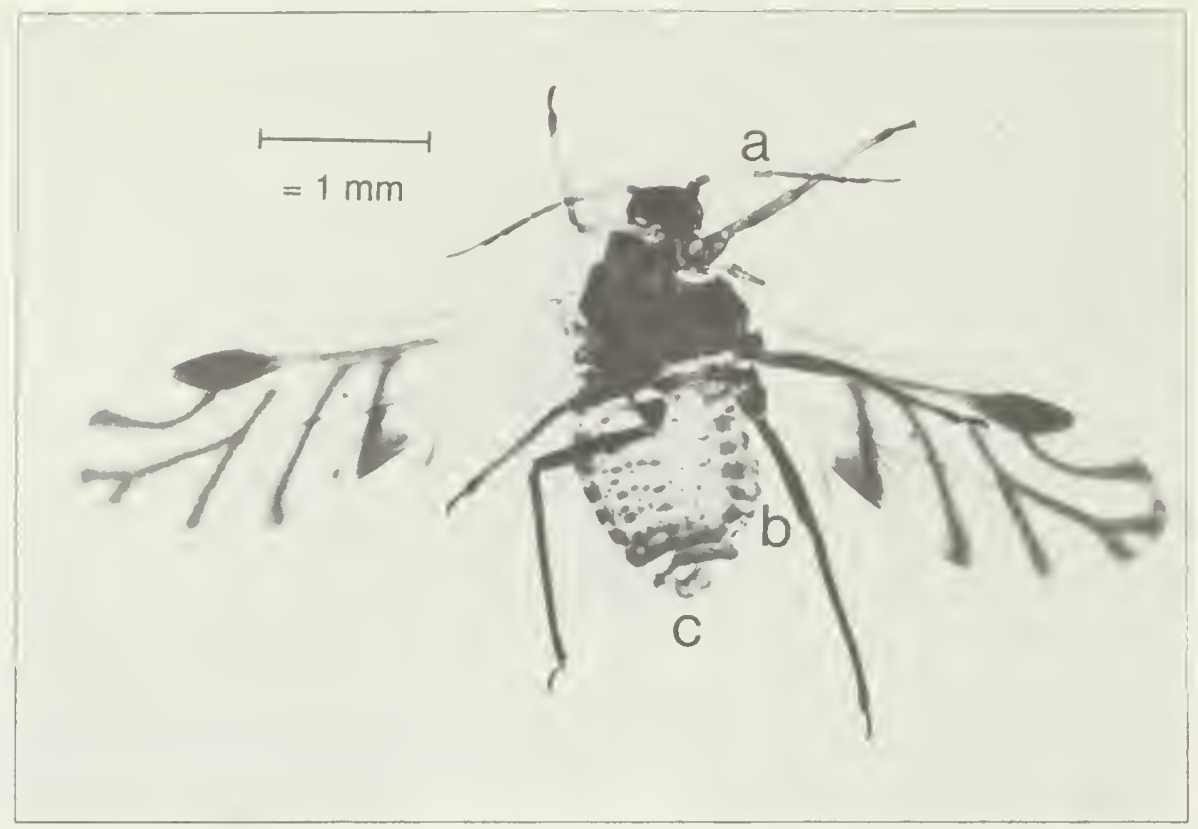

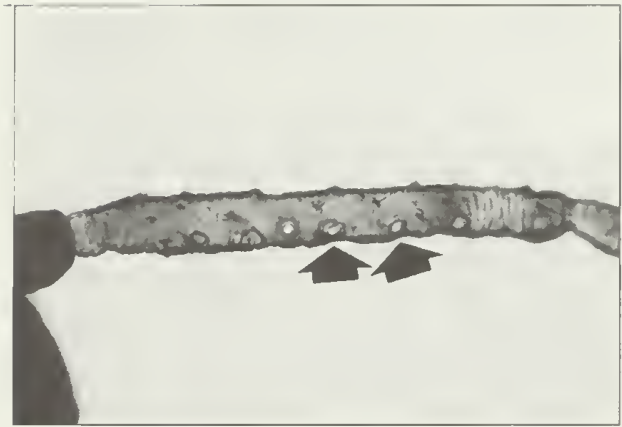

(a) sensoria

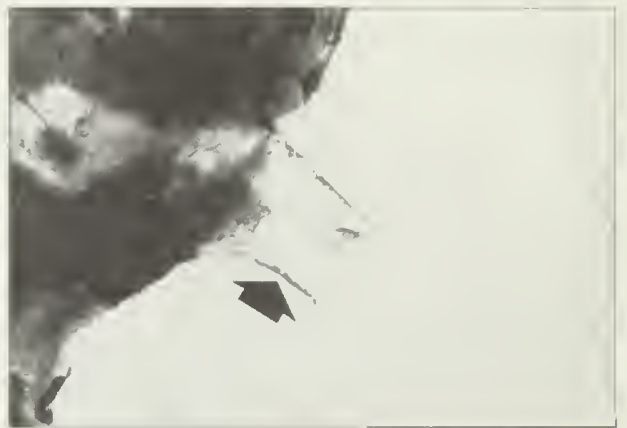

(b) siphunculus

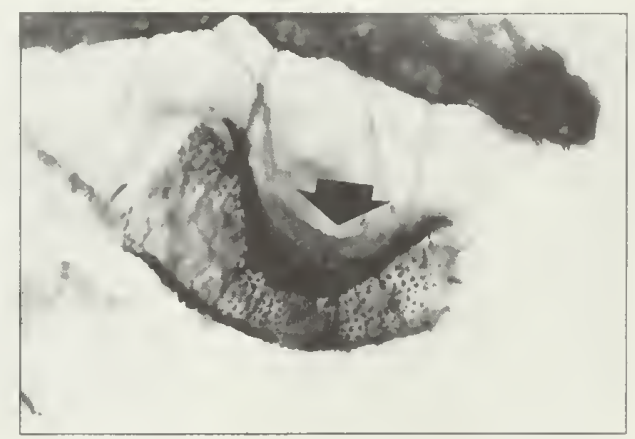

(c) calla

Antennal segment III with circular sensoria that are bordered with narrow rims; antenna (usually) and body with prominent, spine-like setae; abdomen with dusky bands and with lateral spots; siphunculus short, truncate; cauda and anal plate rounded; fore wing with heavily bordered smoky veins. Reference: Palmer 1952. 


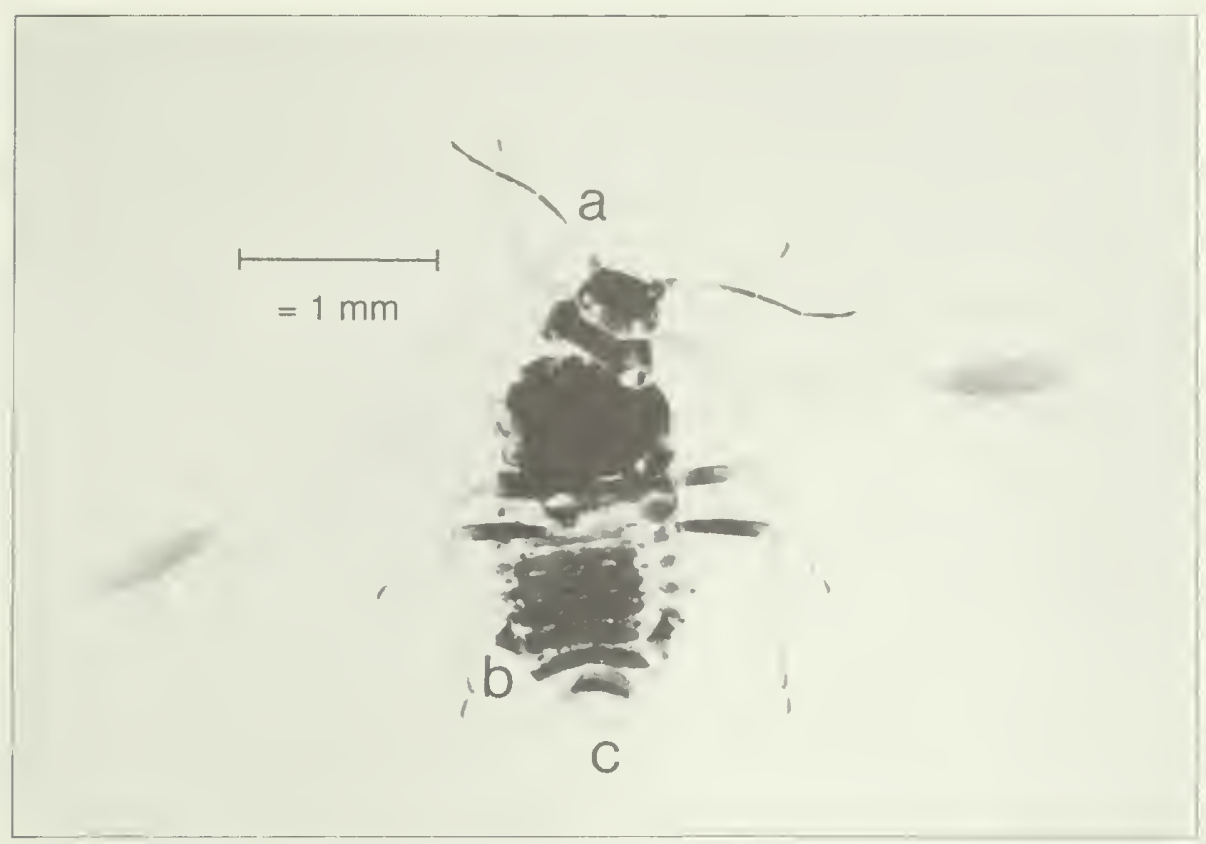

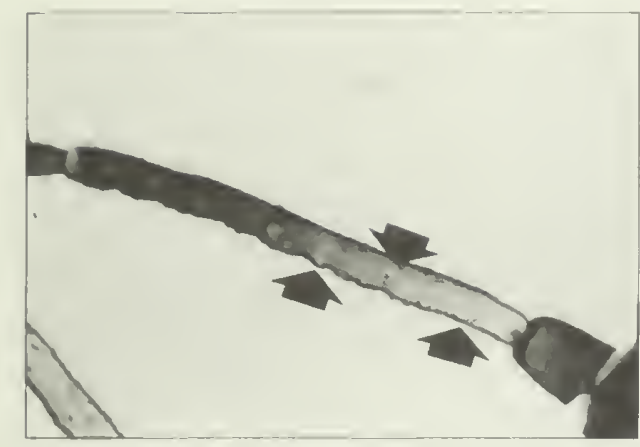

(a) sensoria

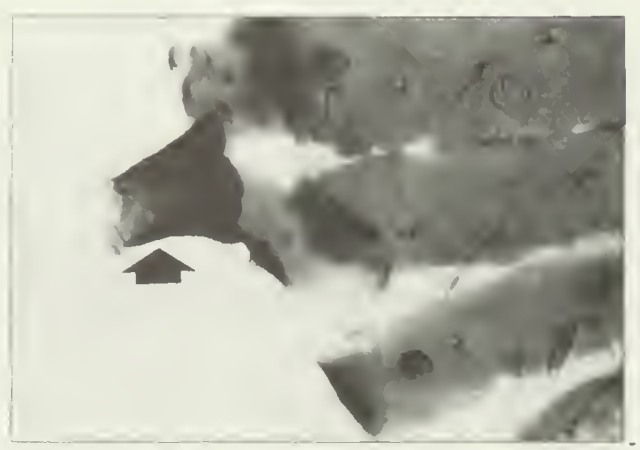

(b) siphunculus

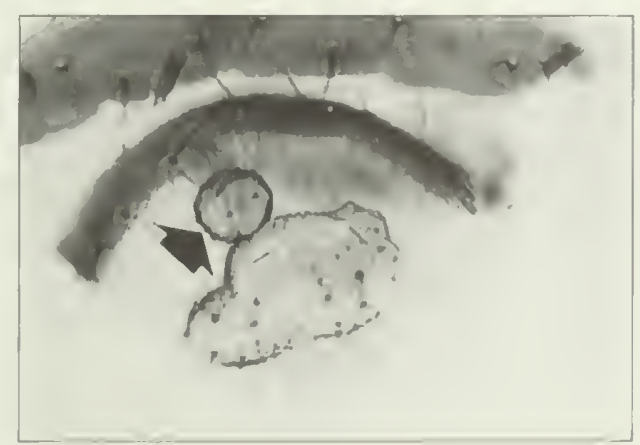

(c) cauda

Antenna dark; antennal segment III with pale base: head and thorax dark; abdomen with dark square patch; siphunculus brown, reticulated; cauda knobbed; anal plate entire. Reference: Richards 1972. 


\section{Chaitophorus pusillus Hottes \& Frison}

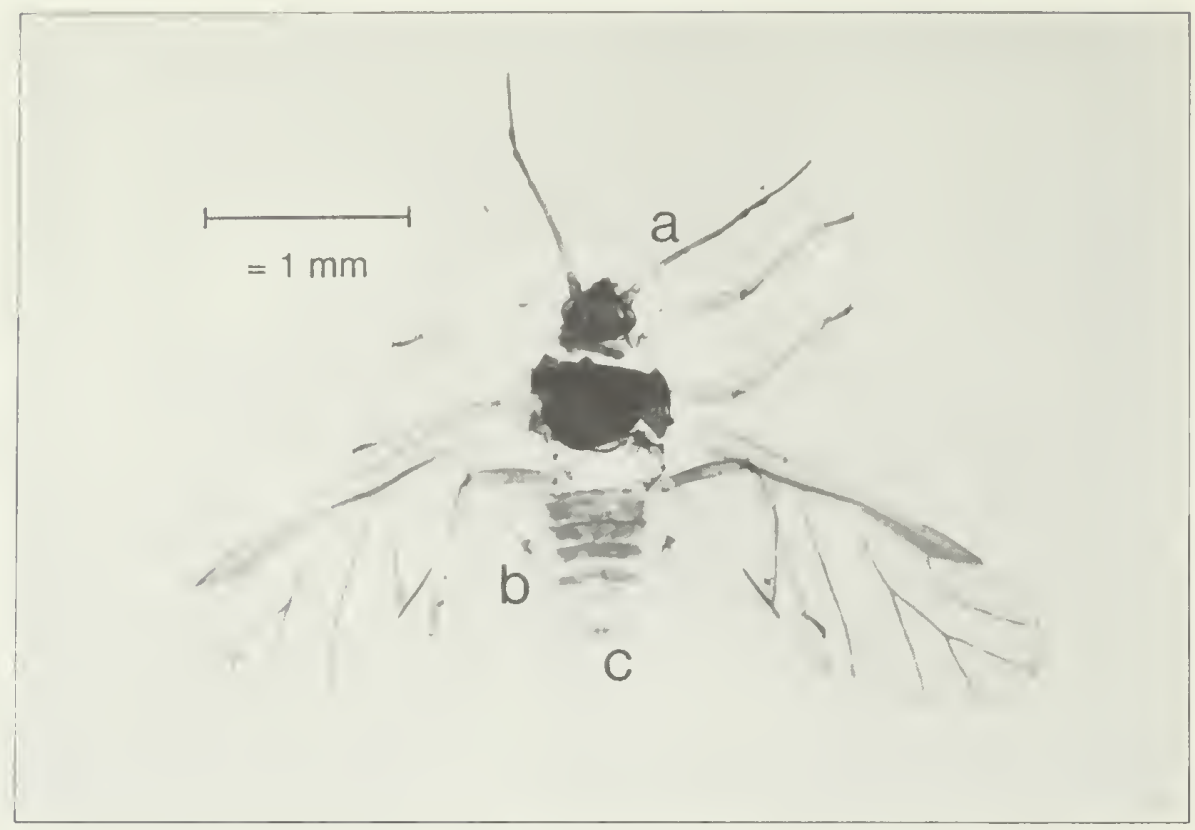

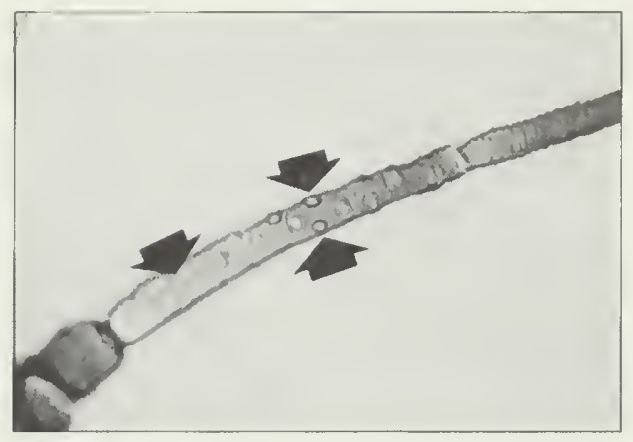

(a) sensoria

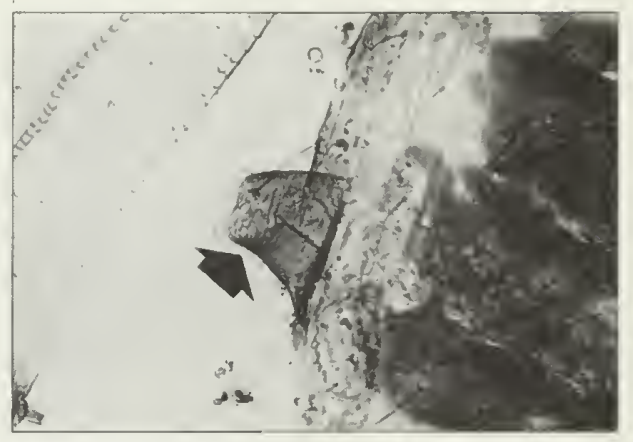

(b) siphunculus

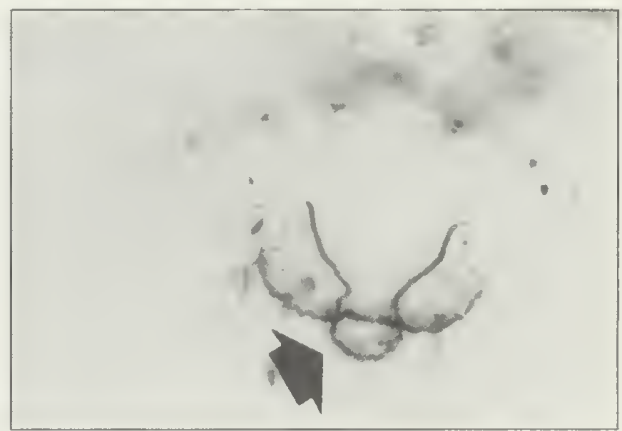

(c) canda

Antennal segment III with pale base; abdomen colorless, with brownish bar on each tergum, the bar partly fused on terga III-VI to form a square patch; siphunculus reticulated; cauda knobbed; anal plate entire; wing veins not pigmented. Reference: Richards 1972. 


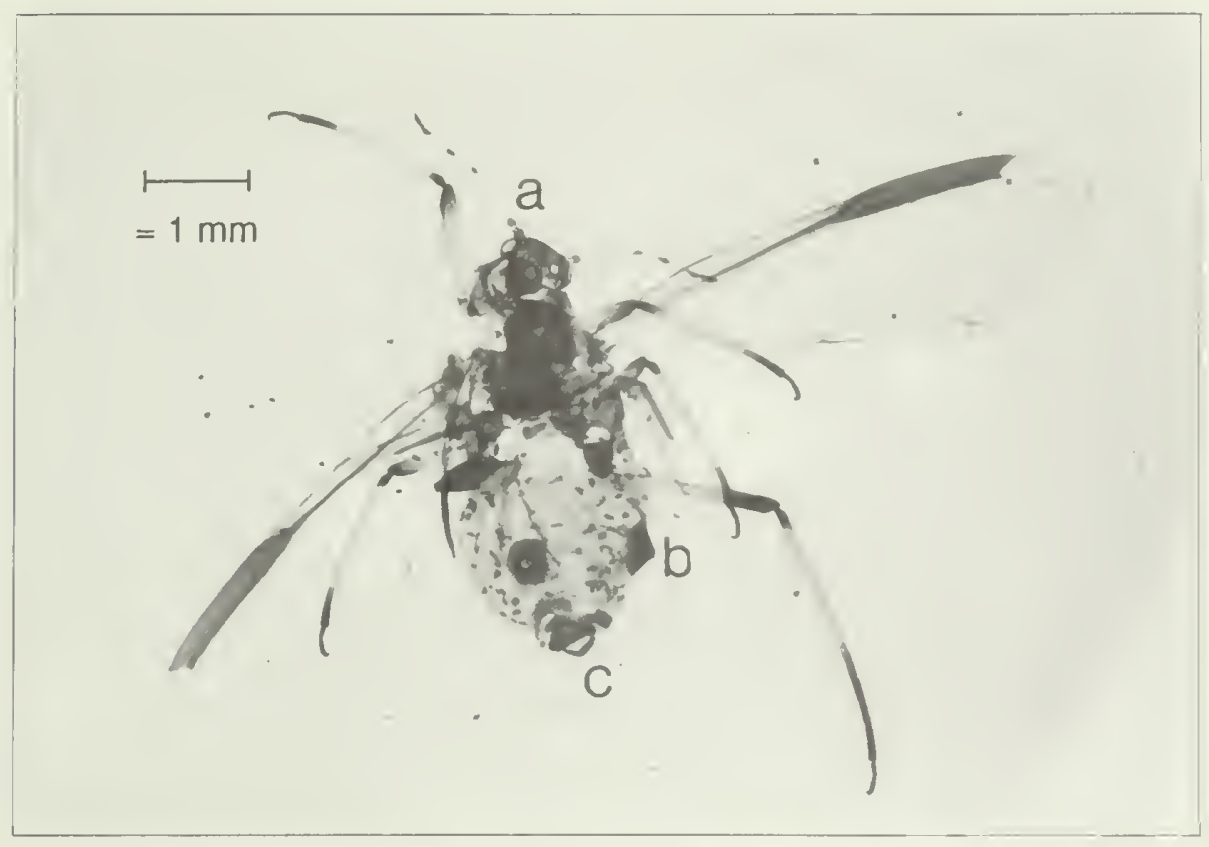

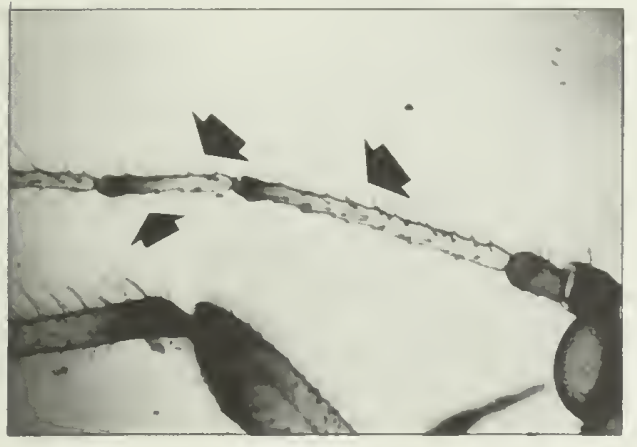

(a) long setae on antenna

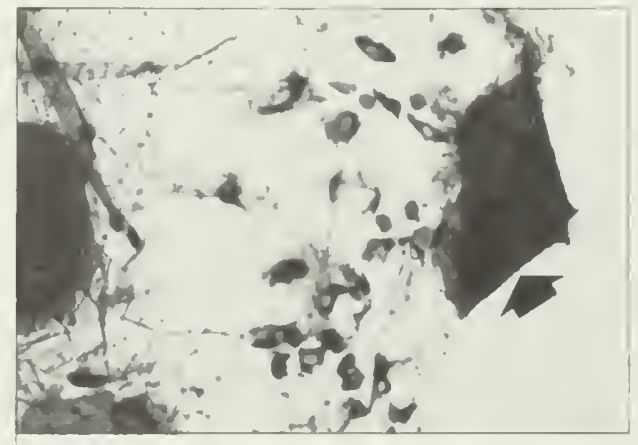

(b) siphunculus

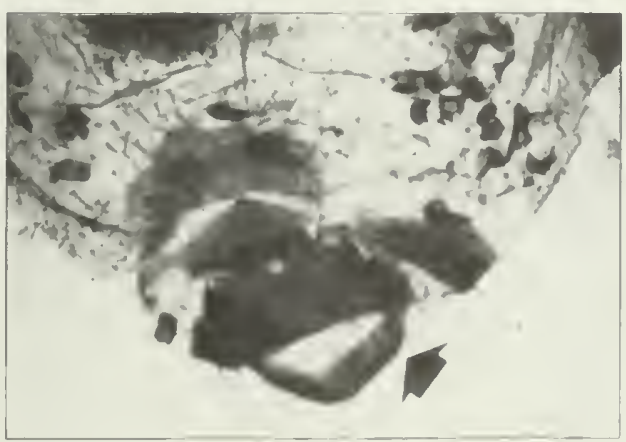

(c) cauda

Aphid large, $3 \mathrm{~mm}$ or more; antenna 6-segmented, with long setae; processus terminalis shorter than half the length of base of antennal segment VI: body robust, bearing numerous, moderate to long, erect setae; siphunculus very short, on pigmented, hairy cone; cauda semicircular, bearing many setae; tibia long. hairy; fore wing with elongated stigma, with straight radial sector, and with faint media that is either 1-or 2-forked. References: Medler and Ghosh 1969. Palmer 1952. 


\section{Cryptomyzus galeopsidis (Kaltenbach)}

European blackcurrant aphid

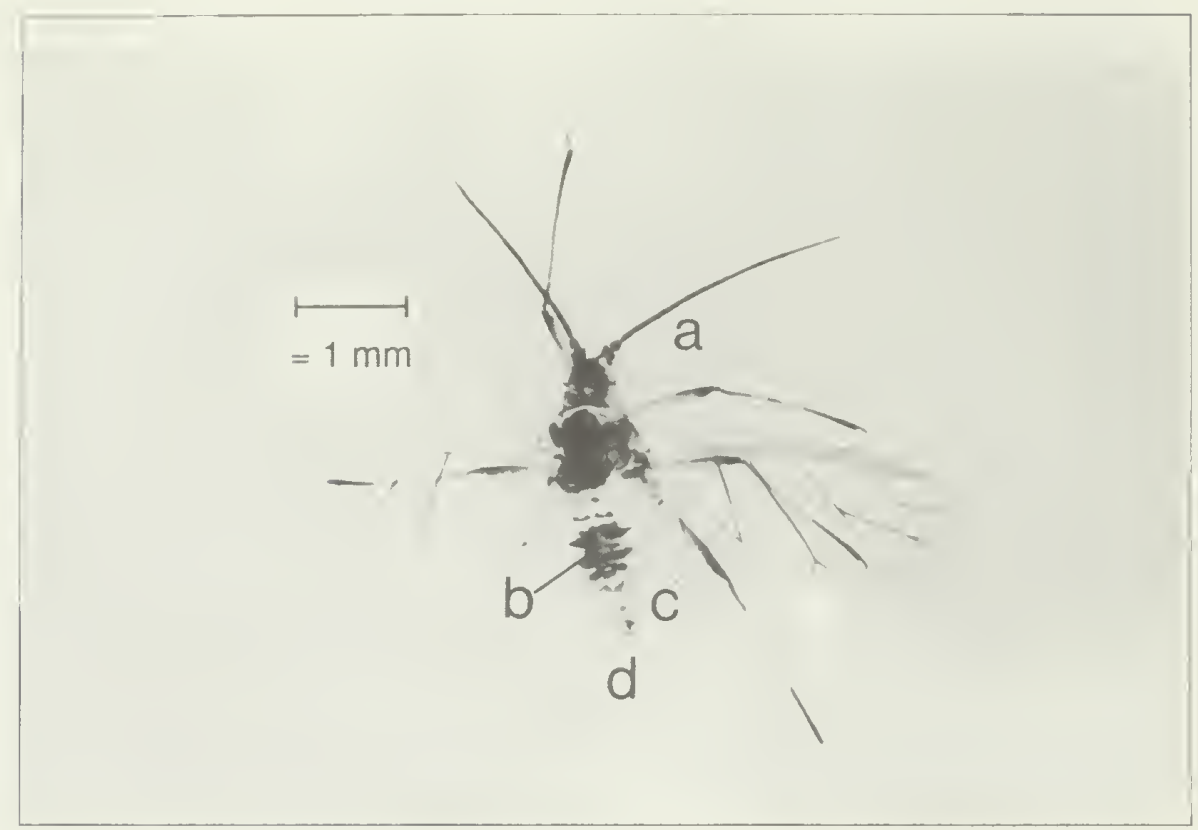

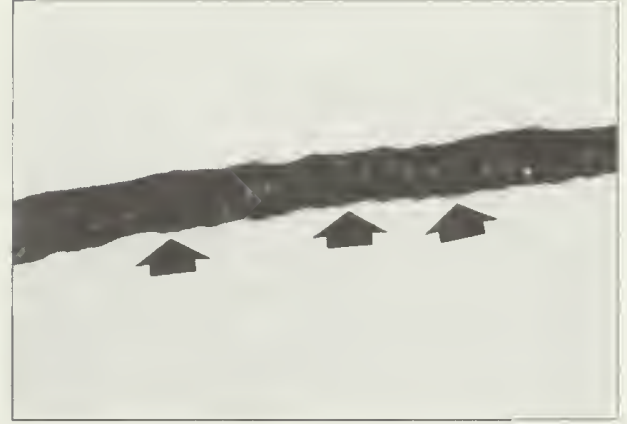

(a) sensoria

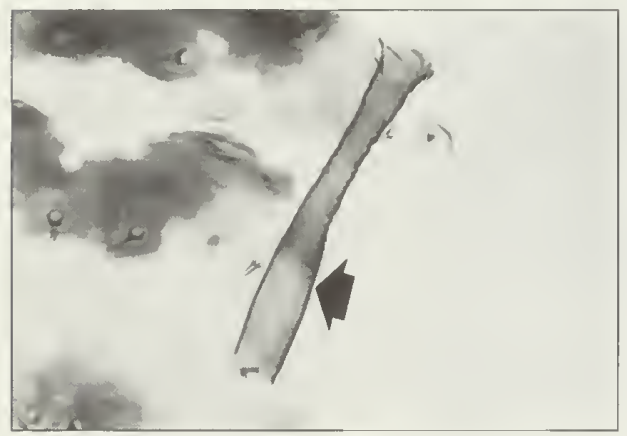

(c) siphunculus

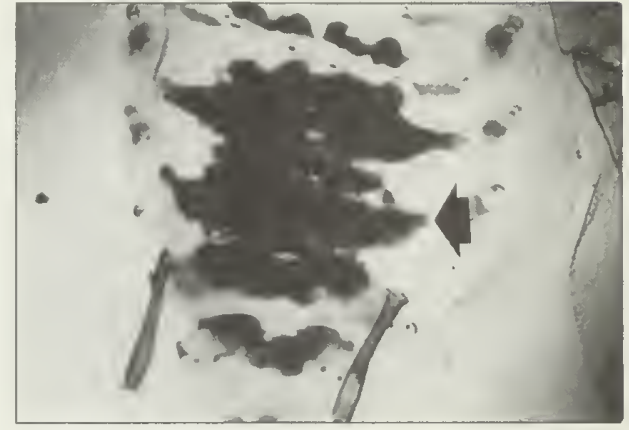

(b) abdominal patch

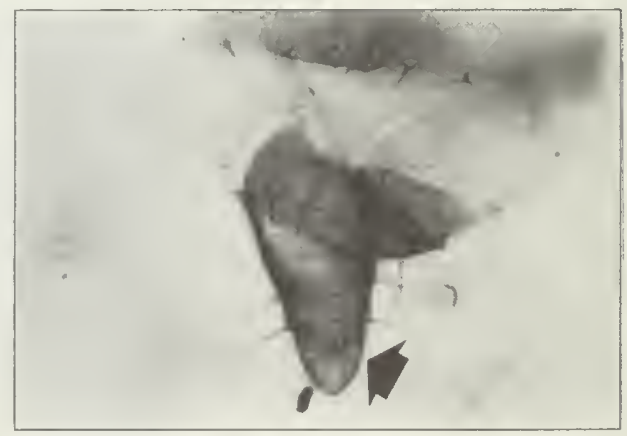

(d) cauda

Antennal segment III with 40-60 sensoria over nearly entire surface; abdomen with dark dorsal transverse bands that sometimes coalesce into a single patch and with very small, brown marginal sclerites; siphunculus brownish, with very thin base and with colorless flange; cauda triangular, with blunt apex, and about half as long as siphunculus. References: Blackman and Eastop 1984, Hille Ris Lambers 1953. 


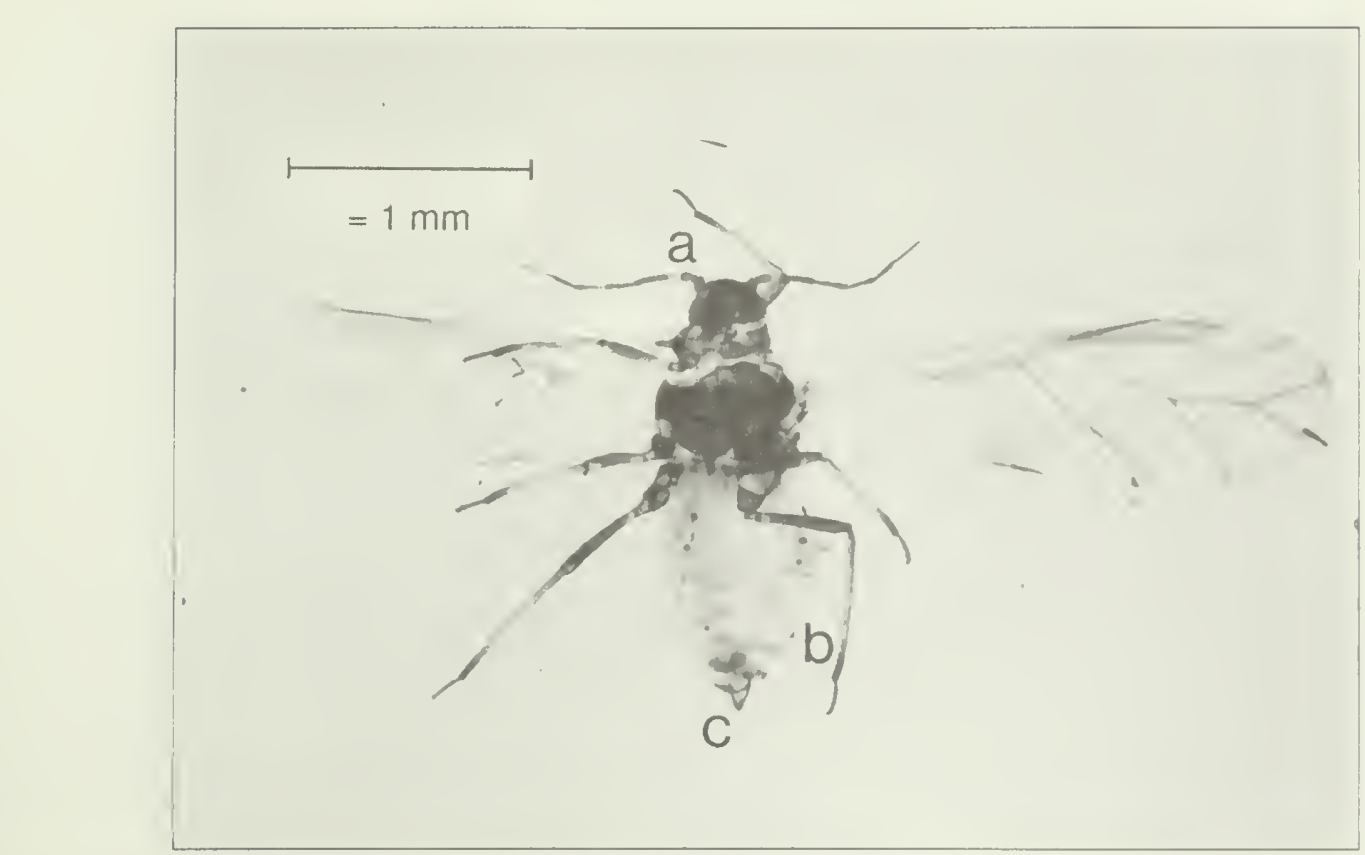

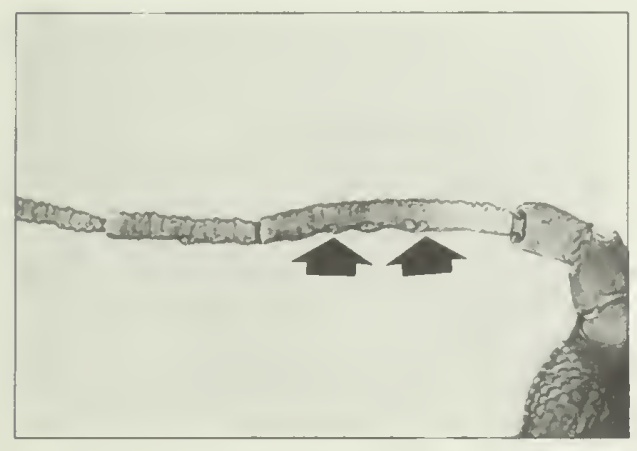

(a) sensoria

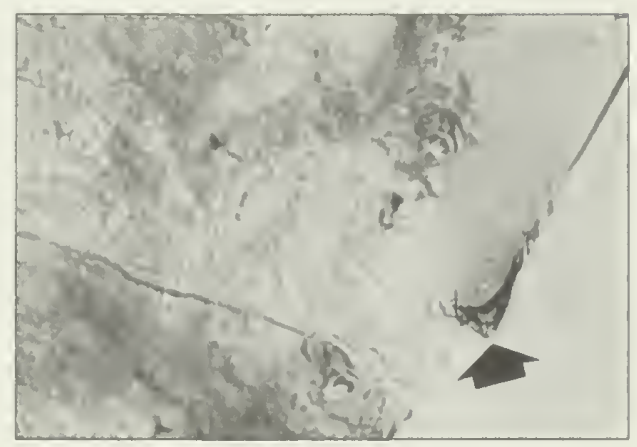

(b) siphunculus

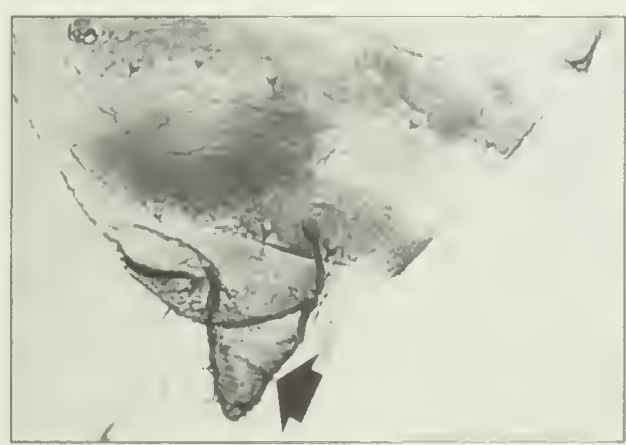

(c) cauda

Antenna about half the body length; antennal segment III with 6-8 sensoria; body very elongate, about 2.5 times as long as broad; siphunculus very short, curved inward, shorter than wide, without flange. Reference: Hille Ris Lambers 1939. 


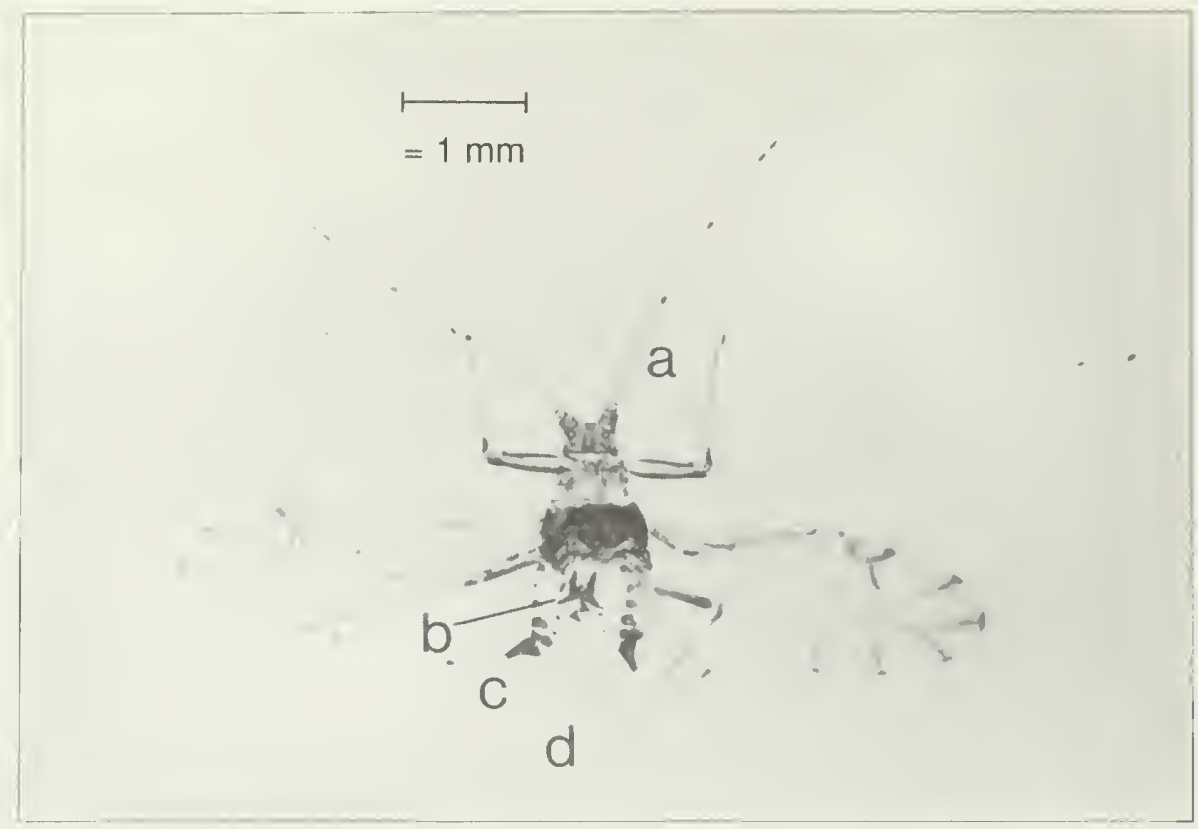

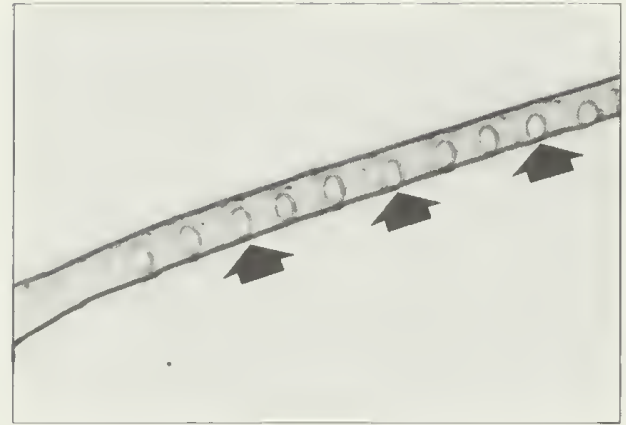

(a) sensoria

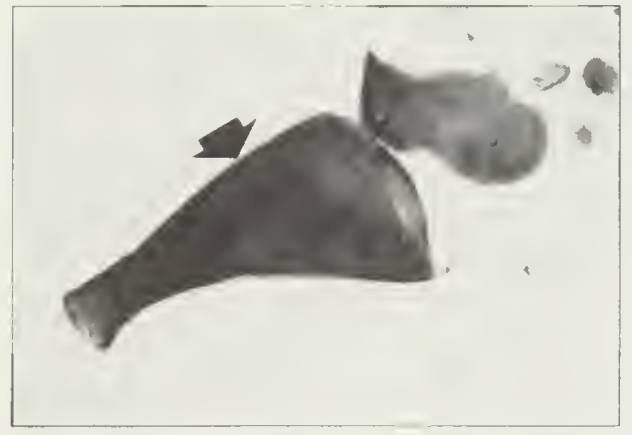

(c) siphunculus

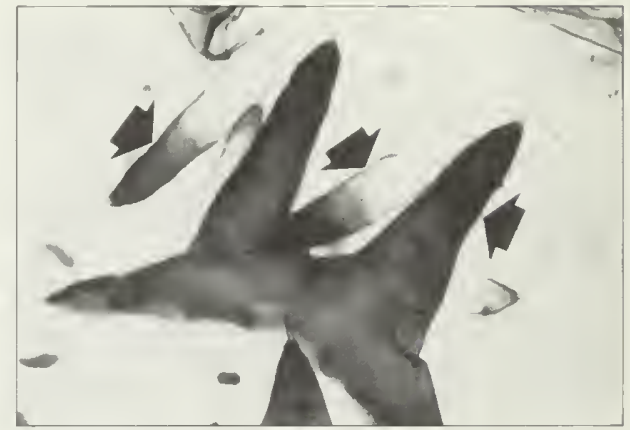

(b) finger-like papillae

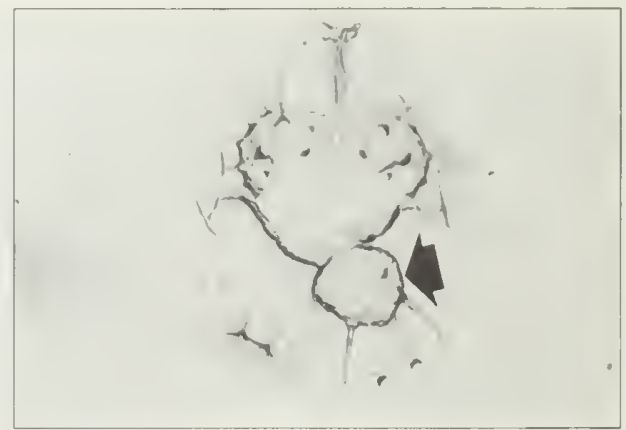

(d) cauda

Antennal segment III with large, ciliated, oval, transverse sensoria arranged in a single row; antennal tubercles well developed; abdominal terga I and III each with a pair of long, finger-like dorsal papillae; abdominal terga II and IV each with a pair of shorter dorsal papillae; siphunculus situated at right angle to body and with distinct swelling at proximal two-thirds portion; cauda knobbed; anal plate indented; fore wing with smoky-bordered veins; stigma dusky, with pale centre. References: Medler and Ghosh 1969, Palmer 1952. 


\section{Drepanaphis simpsoni Smith}

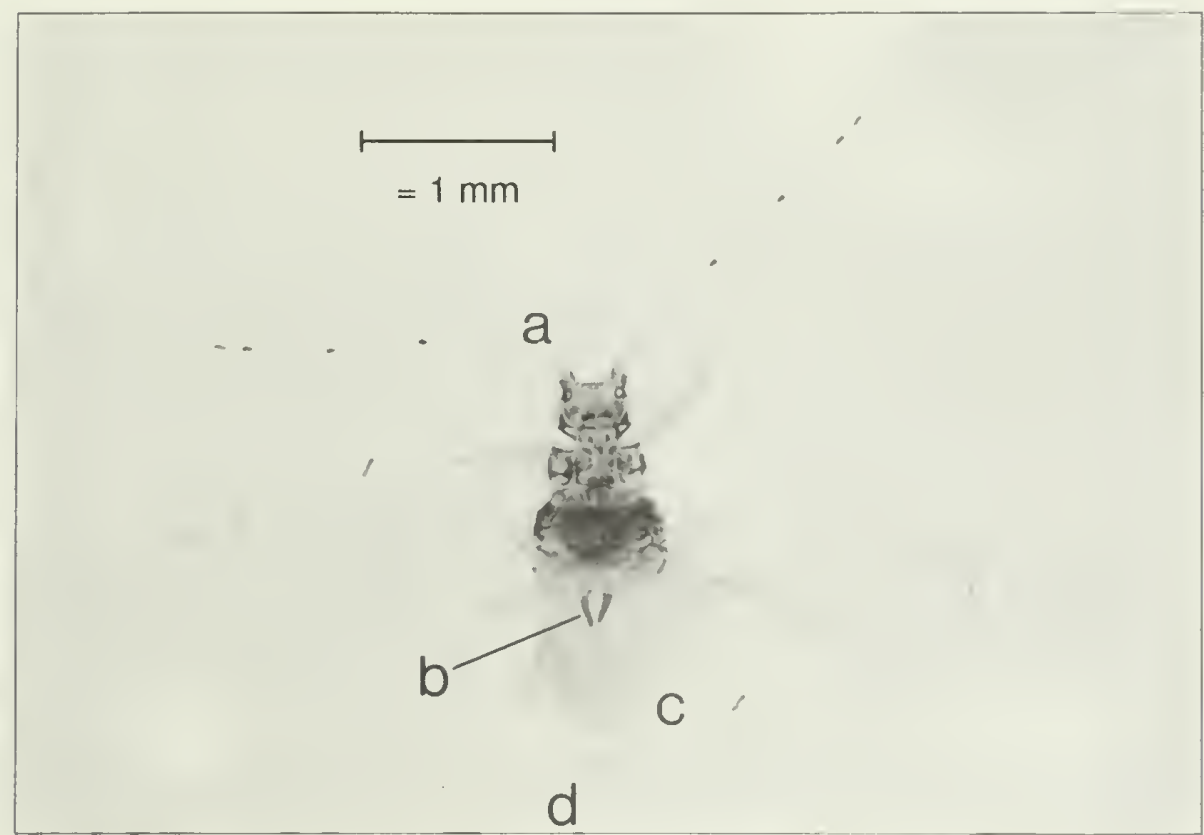

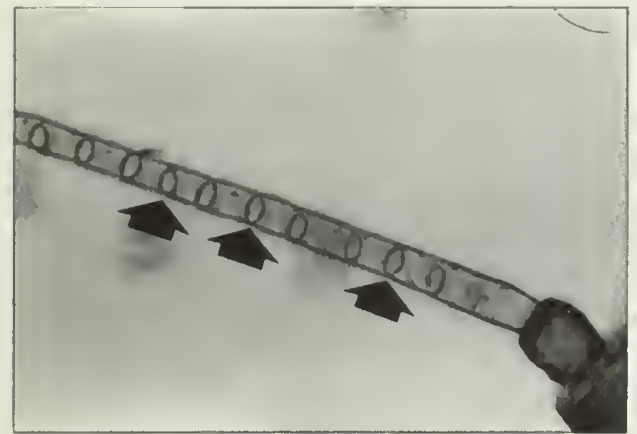

(a) sensoria

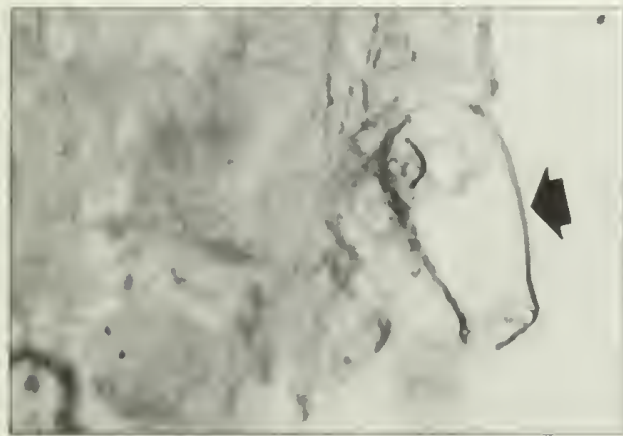

(c) siphunculus

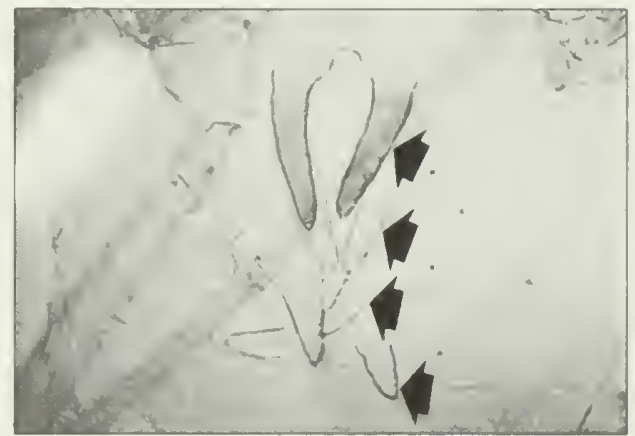

(b) finger-like papillae

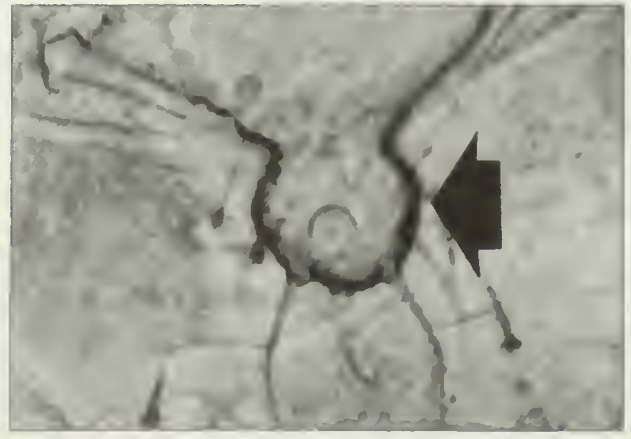

(d) coluda

Antennal segment I as dark as head; other antennal segments pale; antennal segments III, IV, V, and base of VI with dark distal tips; head with 5 light. longitudinal stripes; abdomen nearly colorless, with four pairs of well-developed. finger-like dorsal papillae, the first pair being longer and darker than the others: siphunculus pale; fore wing with smudges on proximal and distal portions of stigma, on base of radius, and around distal portion of radius. Reference: Smith and Dillery 1968. 


\section{Dysaphis (Pomaphis) plantaginea (Passerini)}

rosy apple aphid

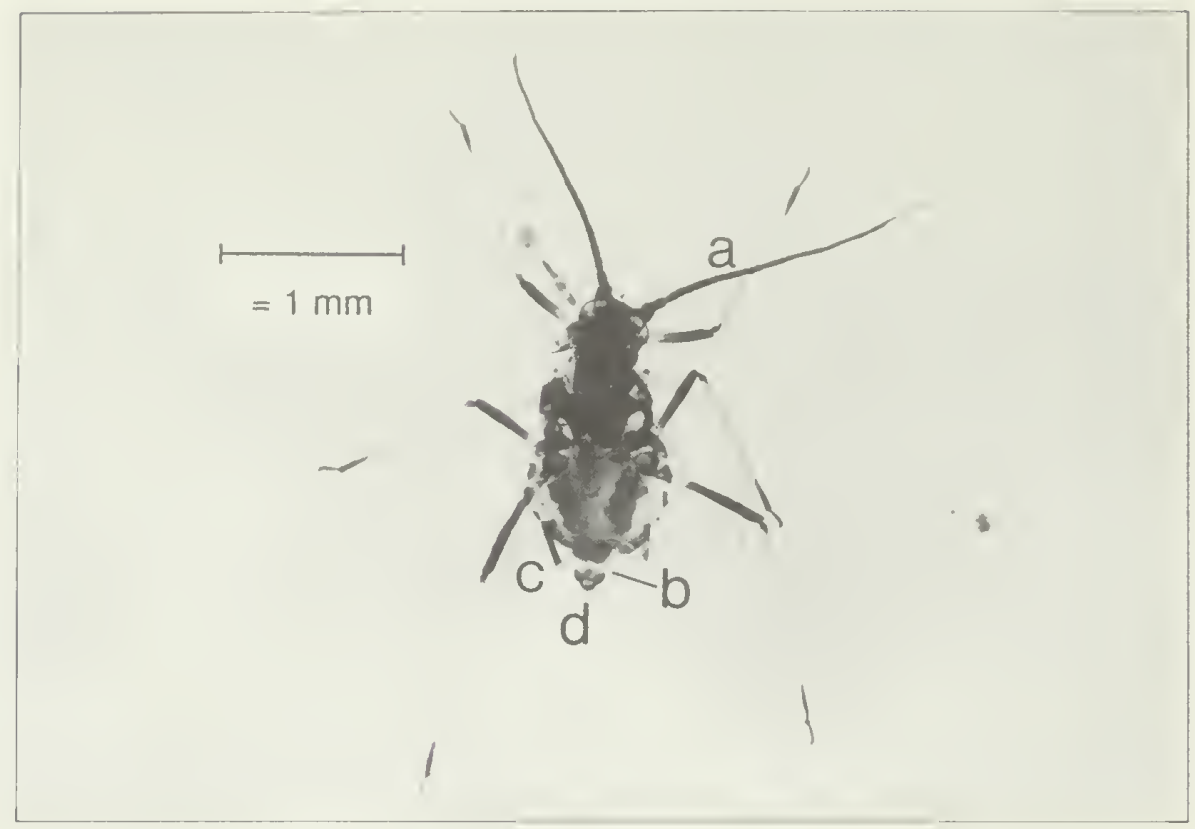

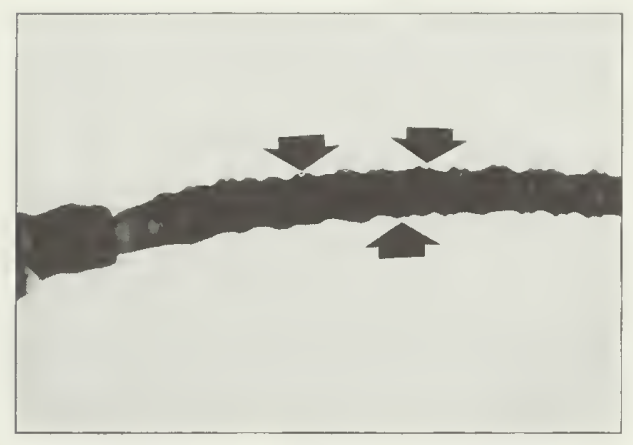

(a) sensoria

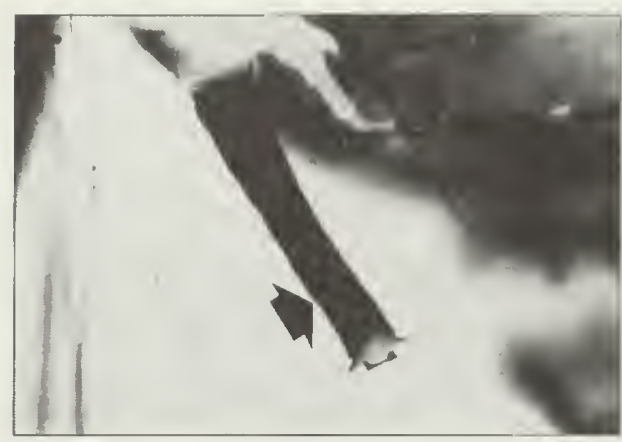

(c) siphunculus

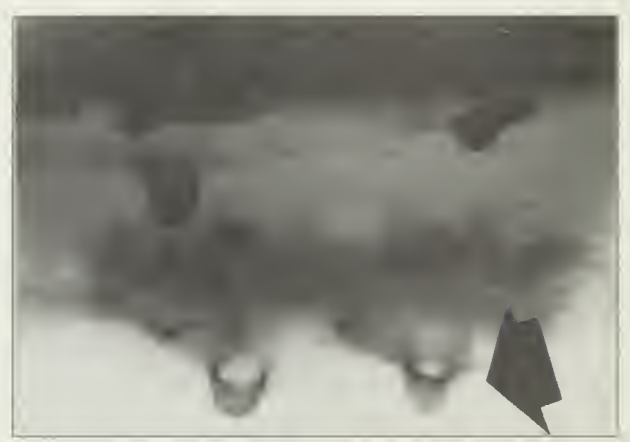

(b) dorsal tubercles

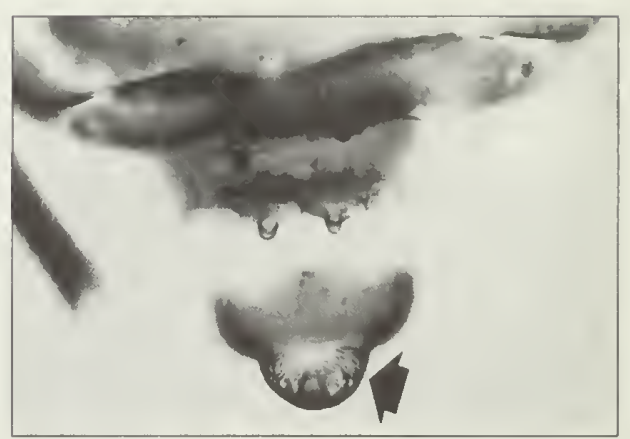

(d) cauda

Antenna shorter than body or slightly longer; antennal segment III with more than 50 knobbly sensoria; head and abdominal terga VII and VIII often bearing dorsal tubercles; abdomen with dark dorsal patch; siphunculus dark, medium length, turned out slightly; cauda short, triangular. References: Medler and Ghosh 1969, Taylor et al. 1984. 
Eucallipterus tiliae (Linnaeus)

basswood aphid

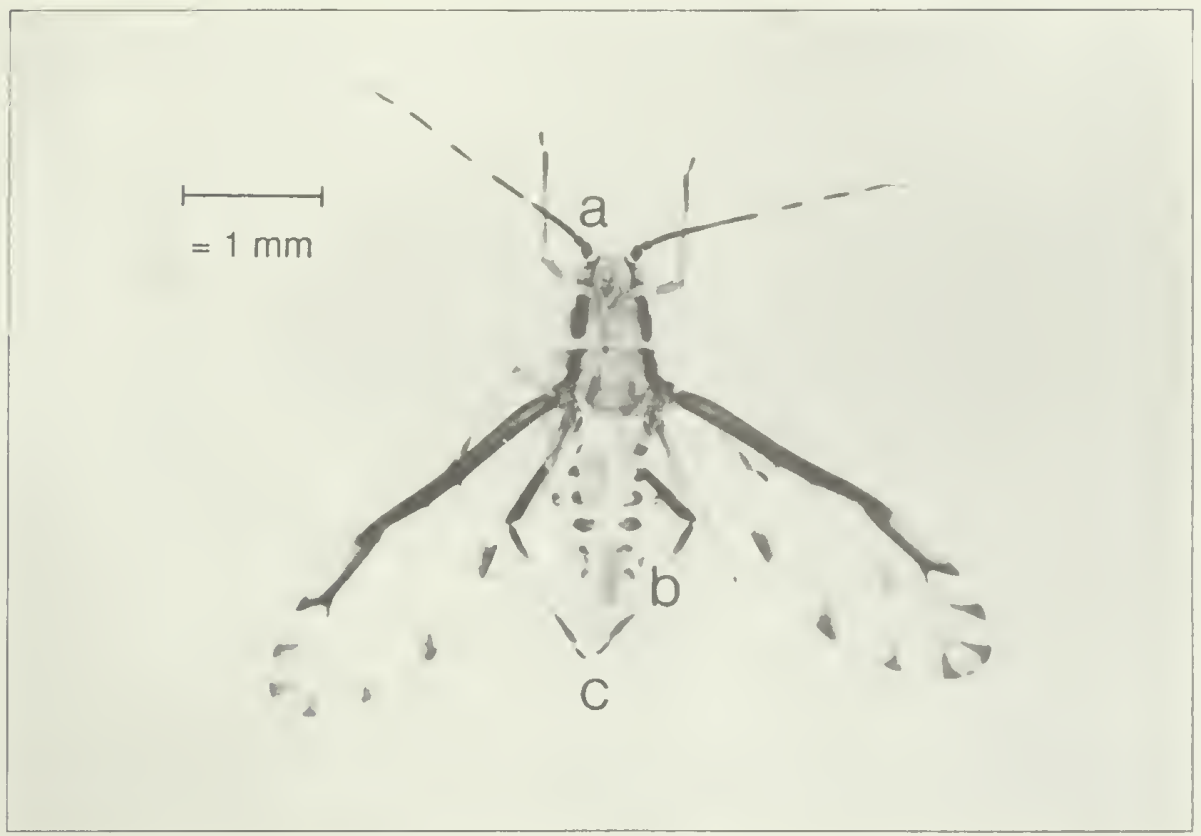

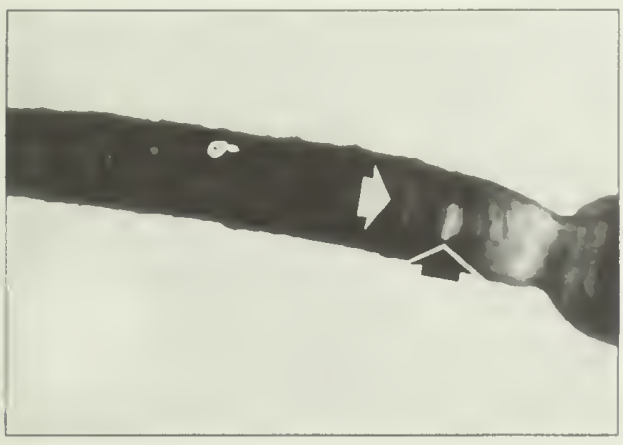

(a) sensoria

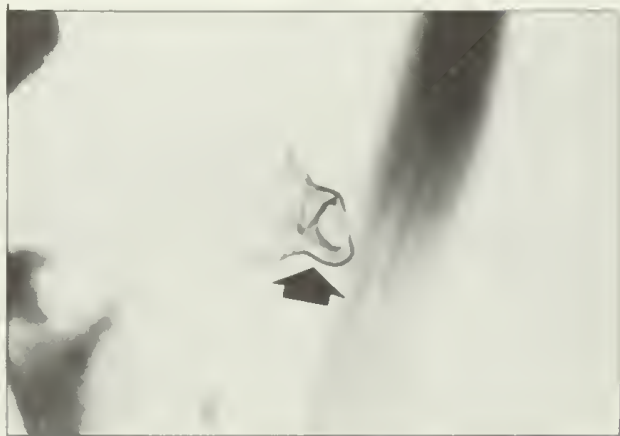

(b) siphunculus

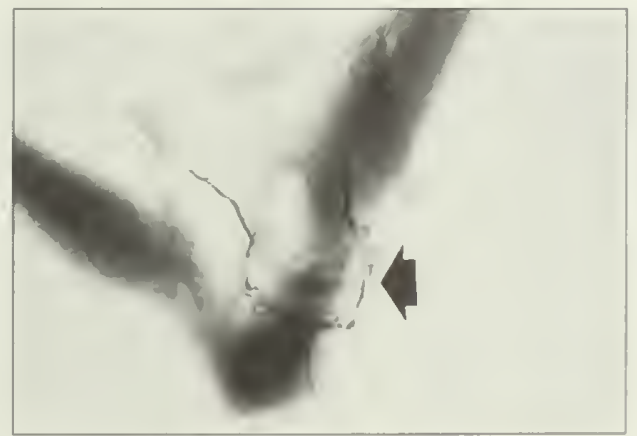

(c) cauda

Antenna black; antennal segment III with pale middle part and with $8-18$ sensoria placed in a row on basal half; antennal segments IV, V, and VI with pale bases; processus terminalis pale; head and pronotum with dark. lateral, longitudinal stripes; abdomen with 2 rows of large, dark dorsal spots; abdominal tergum IV with large, dark, wart-like papillac; siphunculus short, dark, truncate; cauda knobbed; anal plate bilobed; fore wing with dark anterior edge and dark spots at apices of oblique veins. References: Heie 1982, Taylor et al. 1984. 


\section{Forda formicaria von Heyden}

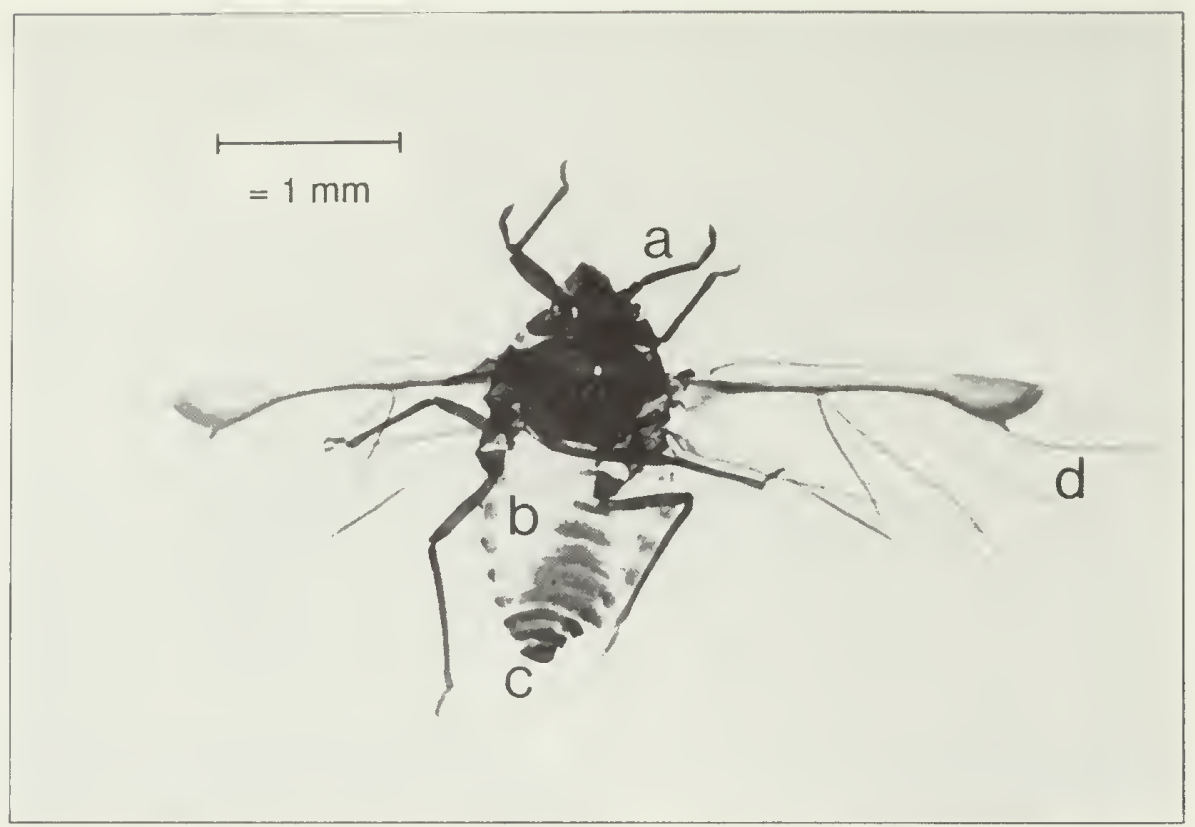

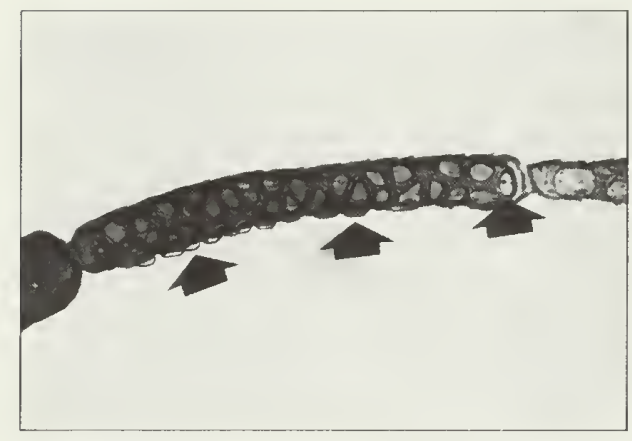

(a) sensoria

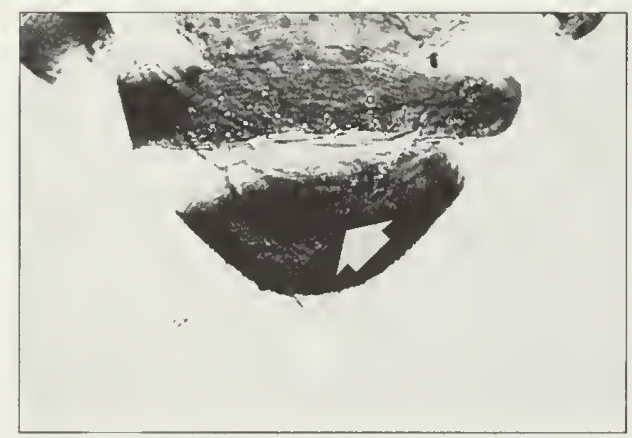

(c) canda

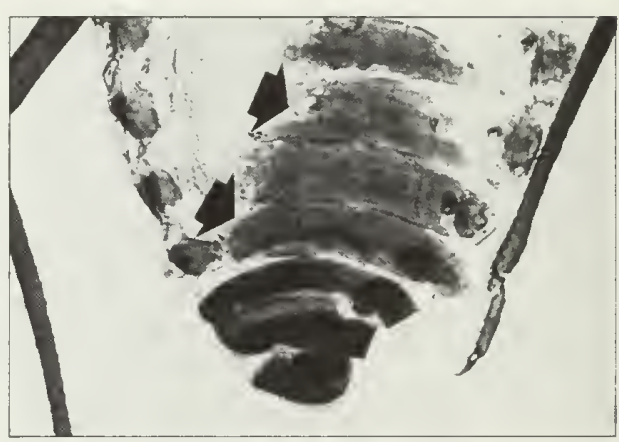

(b) dorsal bands on abdomen

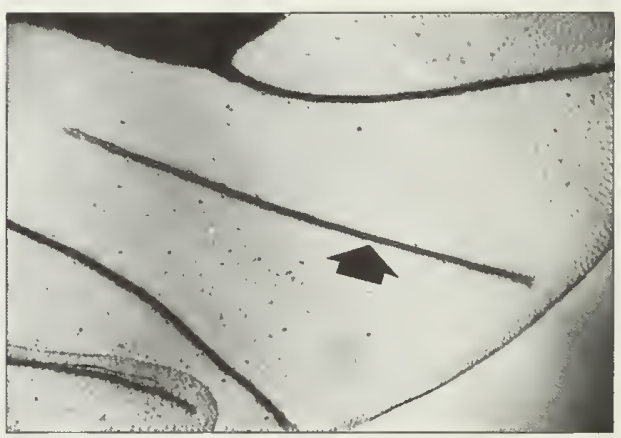

(d) unbranched media of fore wing

Aphid large; antennal segment III with 25 or more sensoria; antennal segment V with large primary sensorium; abdomen with definite dusky dorsal bands and lateral areas; siphunculus absent; cauda rounded, bearing several setae; fore wing with heavy, slightly bordered veins; media unbranched or 1-forked. References: Medler and Ghosh 1969, Palmer 1952, Taylor et al. 1984. 
Grylloprociphilus imbricator (Fitch)

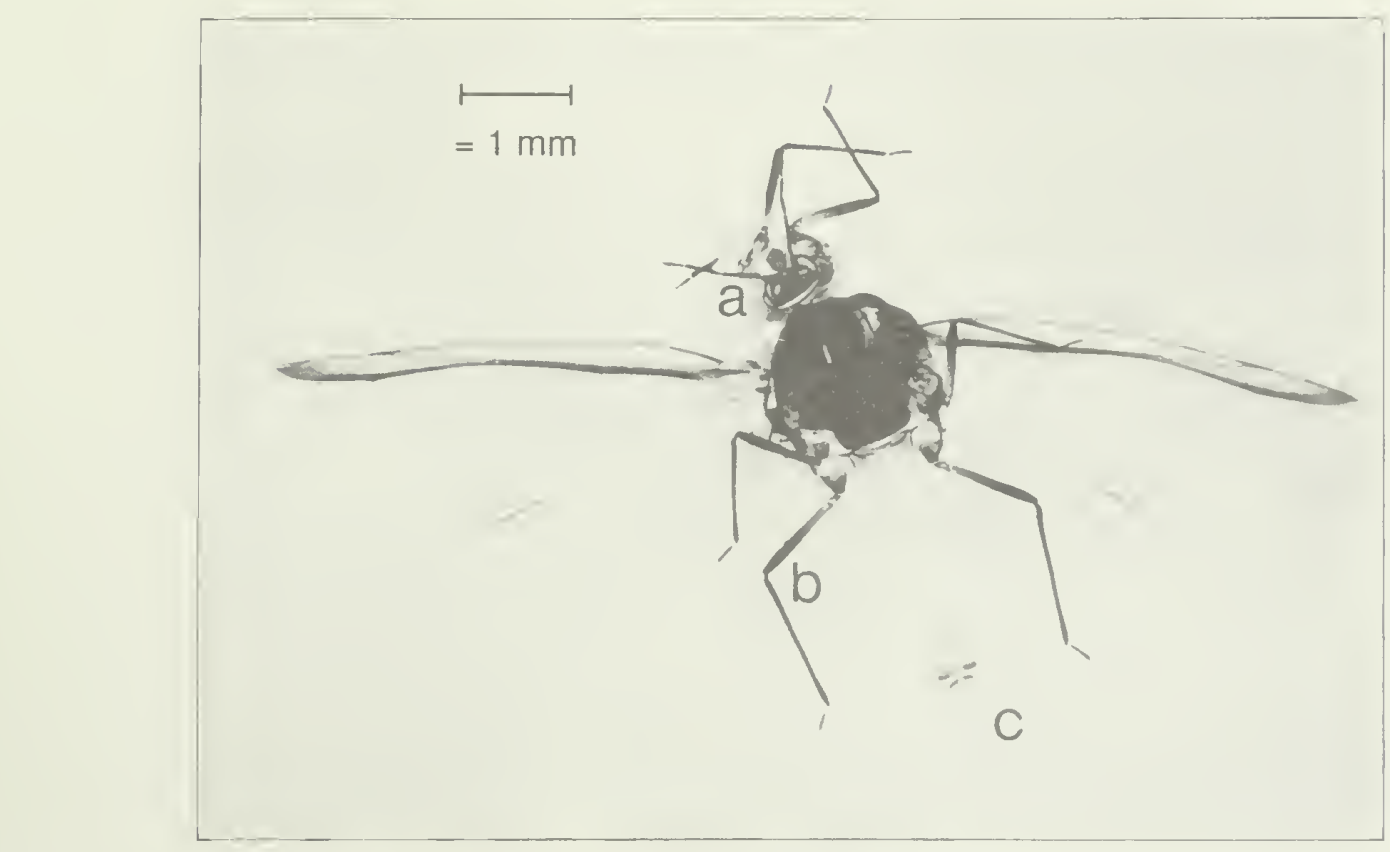

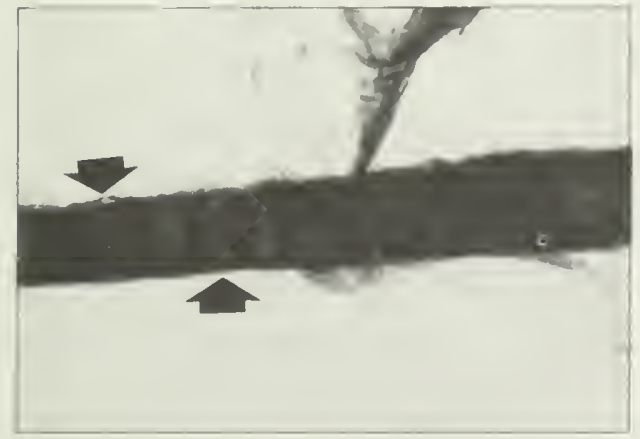

(a) sensoria

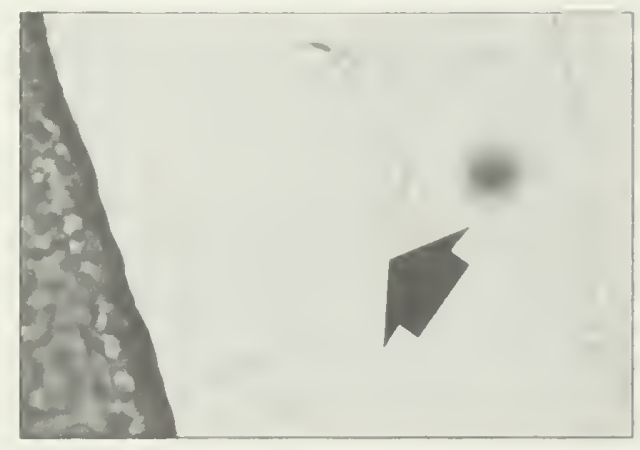

(b) wax plates

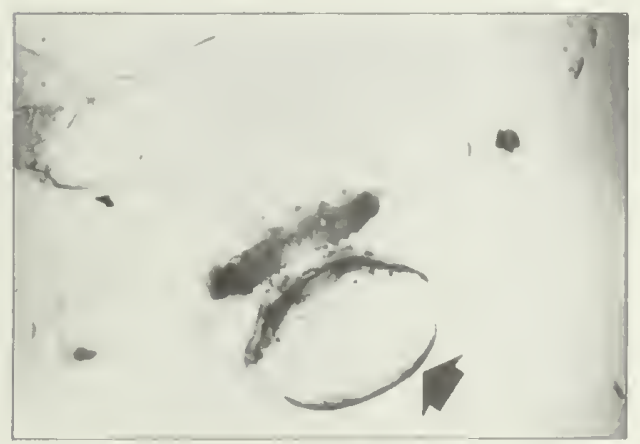

(c) cauda

Antennal segment III with circular to oval sensoria arranged in a single row: abdomen with distinct marginal wax plates; siphunculus present but indistinct: cauda rounded; differs from Pemphigus sp. in the form of the antennal sensoria. Reference: Smith 1974. 


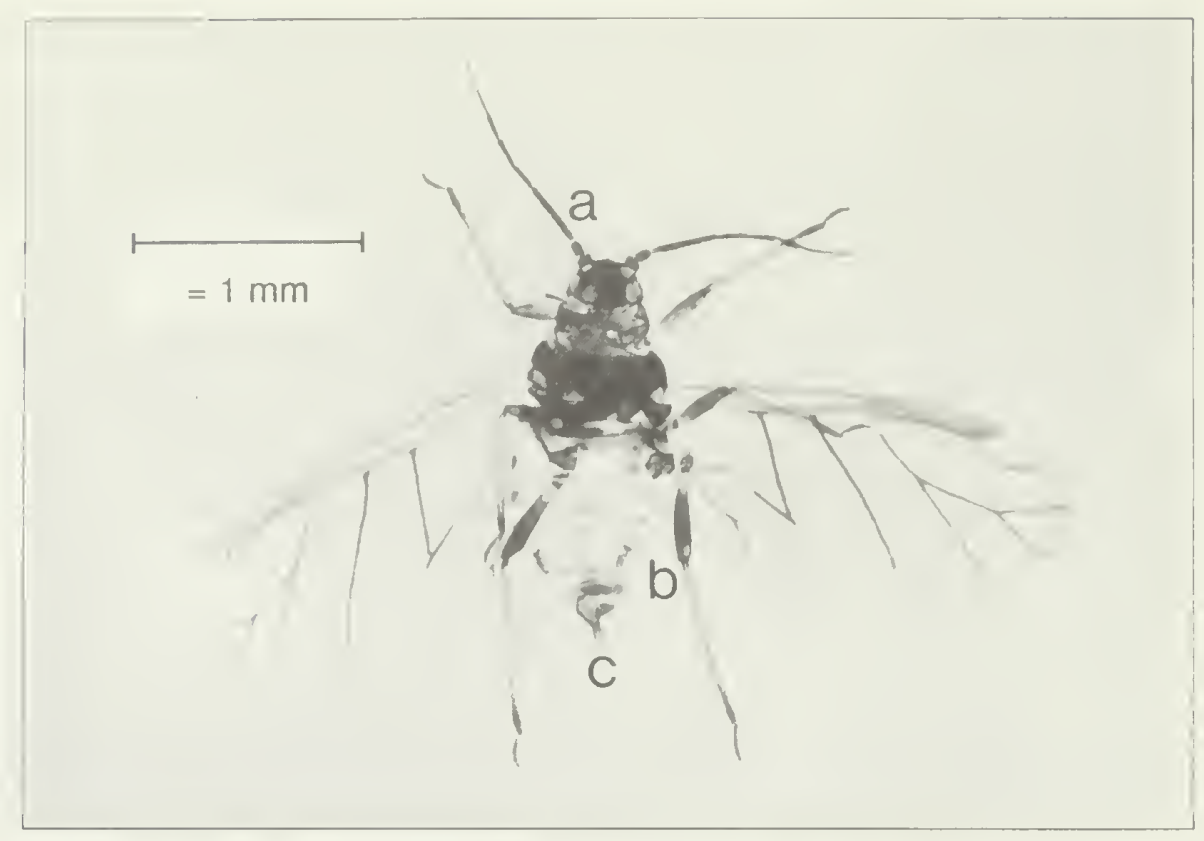

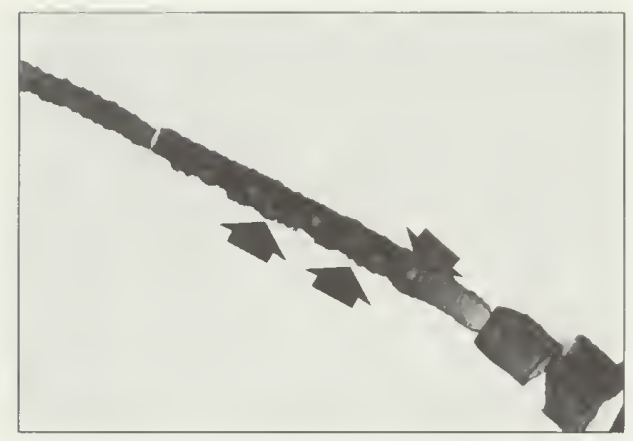

(a) sensoria

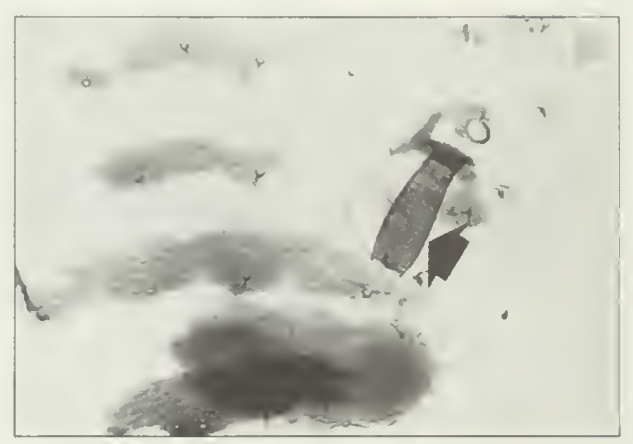

(b) siphunculus

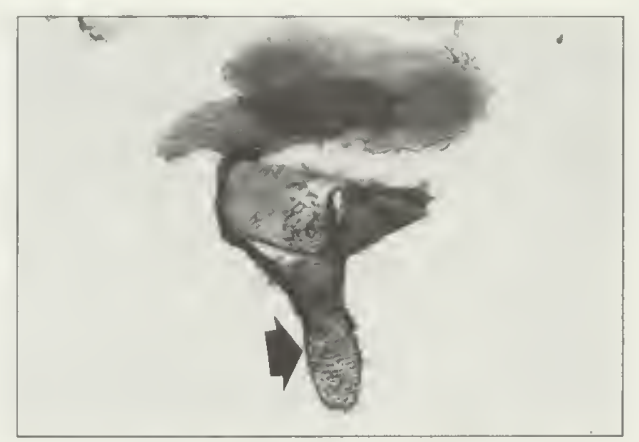

(c) cauda

Antennal segment III with 12-18 sensoria; other antennal segments lacking sensoria; prothorax and all abdominal terga with lateral tubercles; abdomen light, with darker lateral areas and darker dorsal crossbands; siphunculus twice as long as maximum width, smooth, slightly swollen near apex, and with flange; cauda elongate, spoon-shaped. References: Palmer 1952, Taylor et al. 1984. 
Hyadaphis tataricae (Aizenberg)

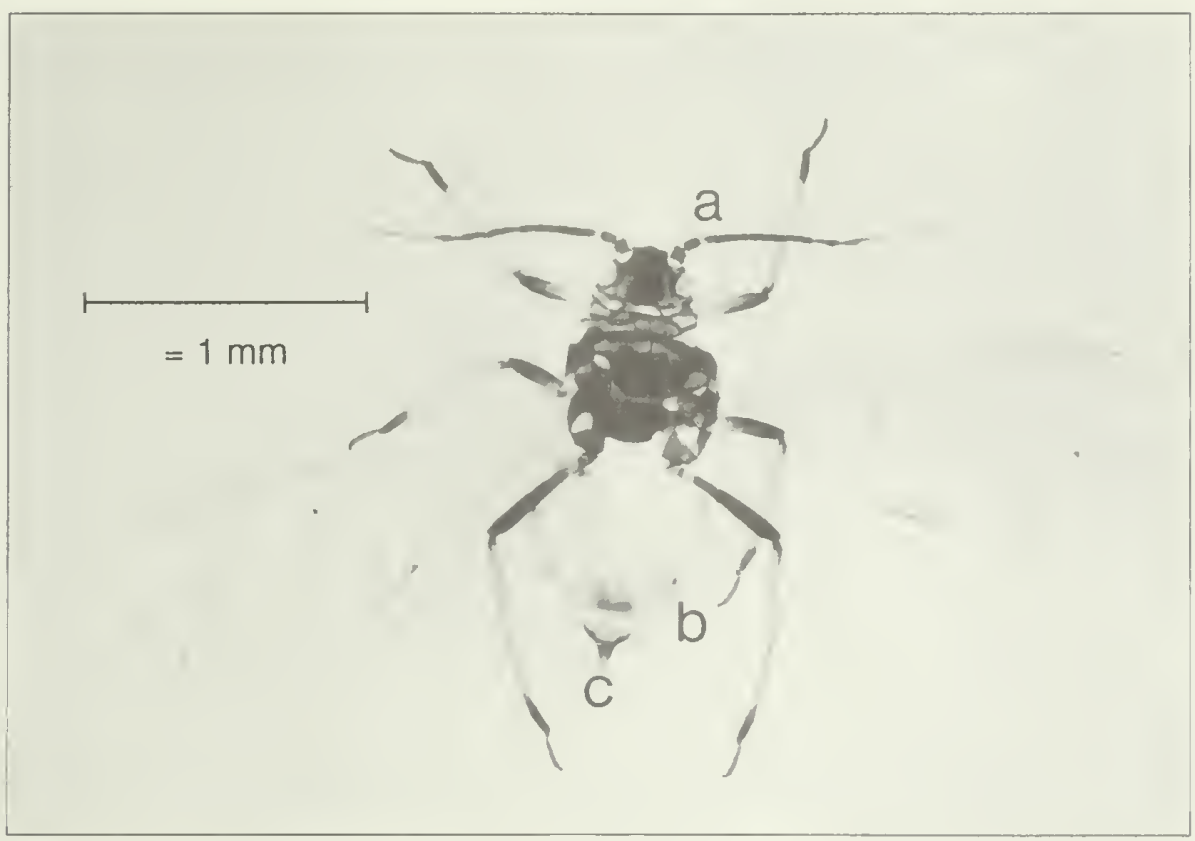

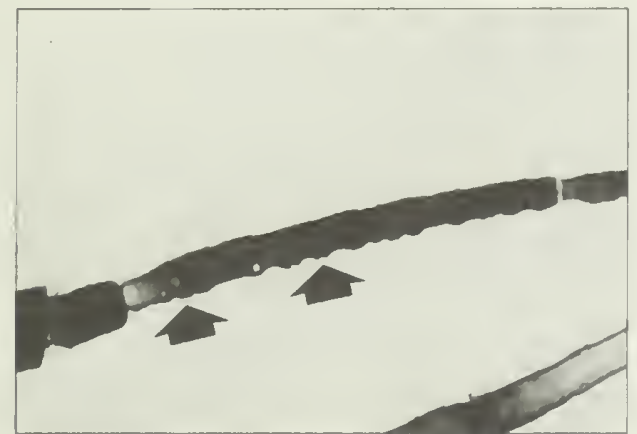

(a) sensoria

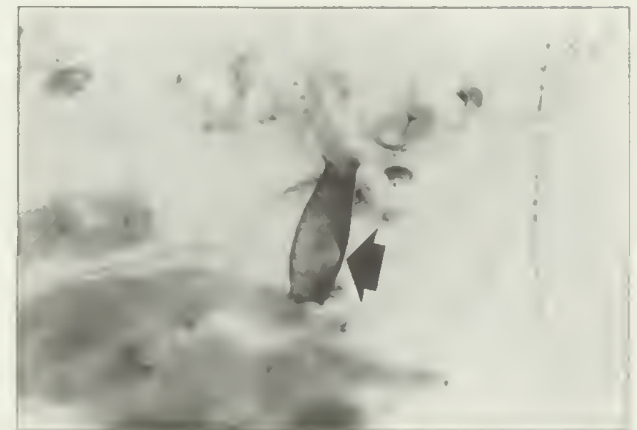

(b) siphunculus

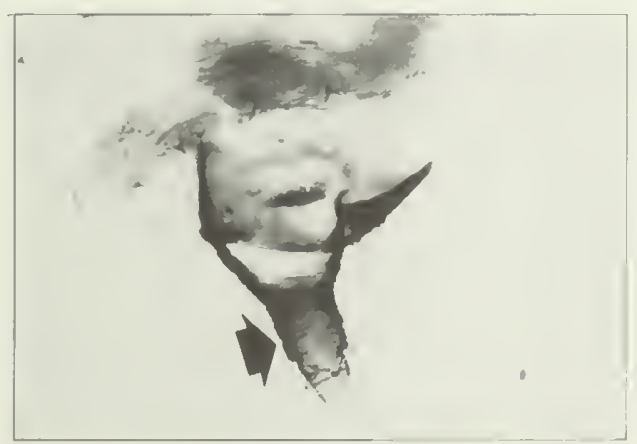

(c) cauda

Antenna dark, except for small pale region at base of segment III: abdomen pale, smooth, with irregular dusky areas on terga II-VII; siphunculus pale, faintly imbricated, slightly swollen, but constricting below tip; cauda triangular. Reference: Voegtlin 1984. 


\section{Hyalomyzus eriobotryae (Tissot)}
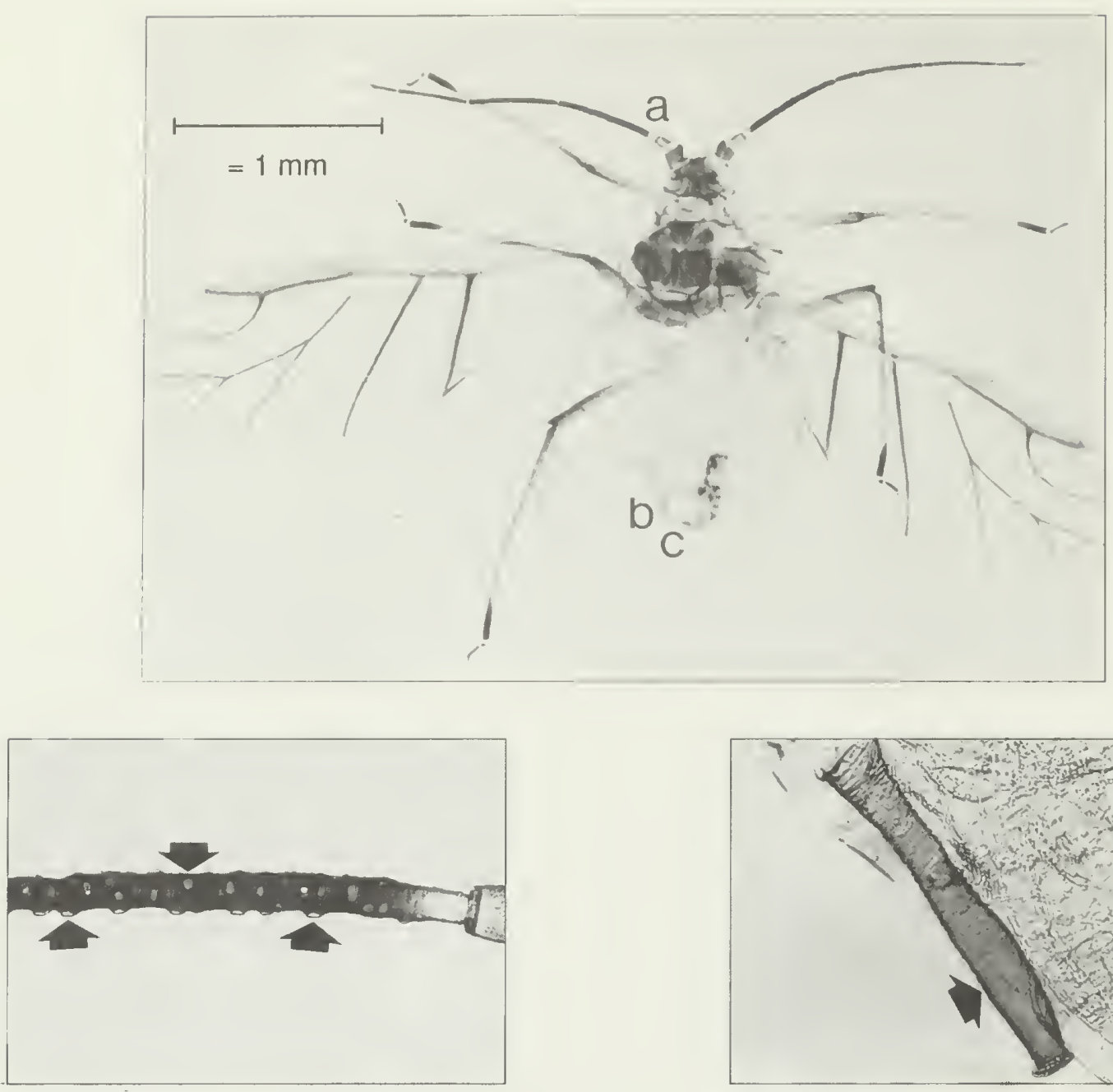

(a) sensoria

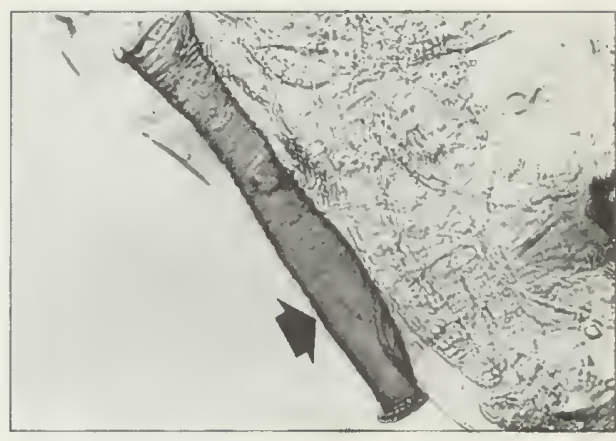

(b) siphunculus

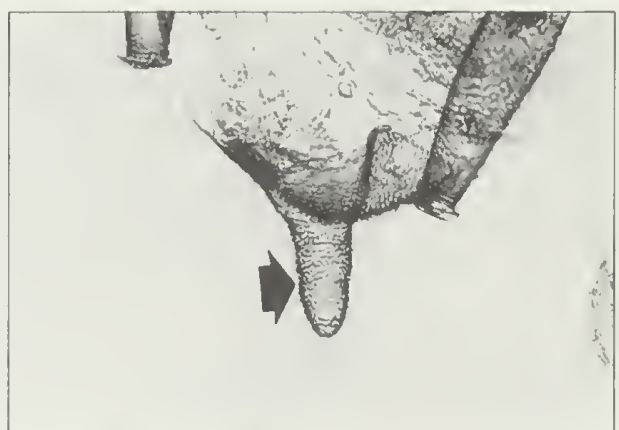

(c) canda

Antennal segment III with 35 or more evenly scattered sensoria; antennal segments IV and V also with many sensoria distributed evenly over entire surface of segments; abdomen not strongly wrinkled, lacking pigmented sclerotic areas dorsally but having dark, well-developed sclerites laterally. References: Nielsson and Habeck 1971, Richards 1958. 


\section{Hyperomyzus sp. Börner}

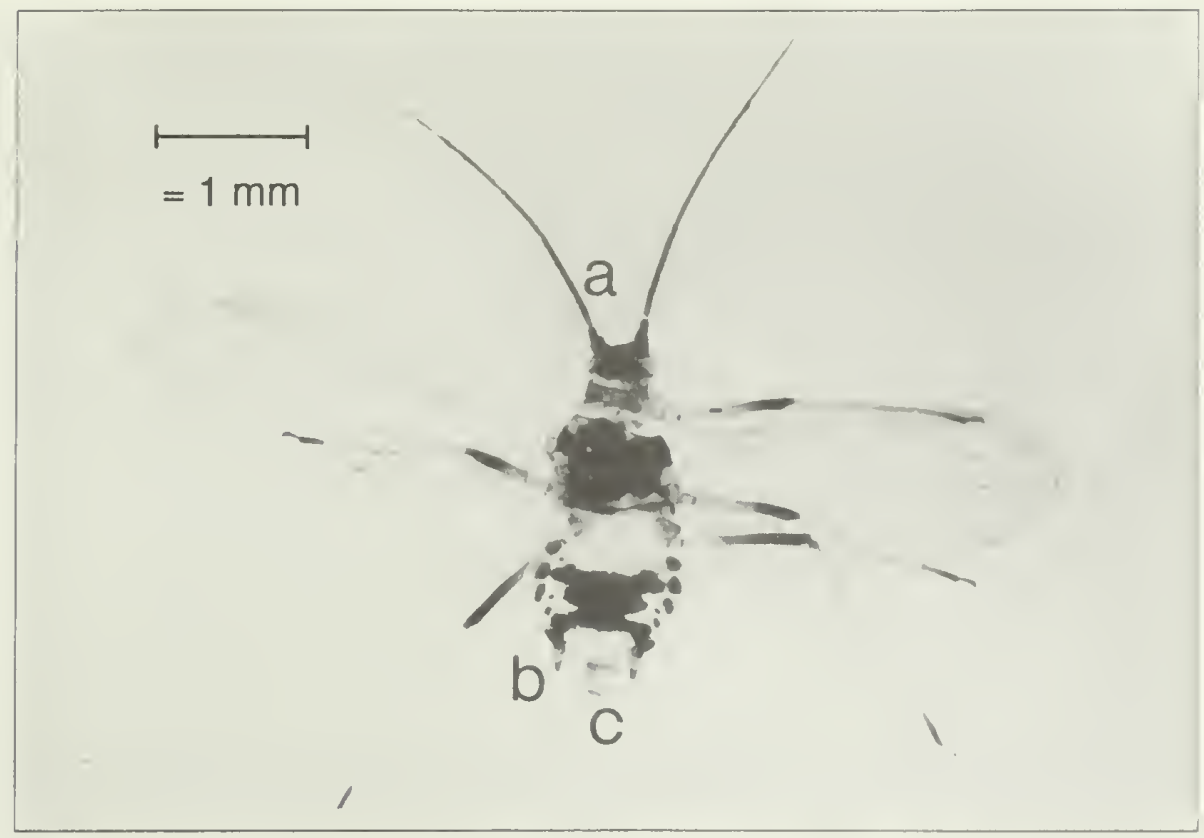

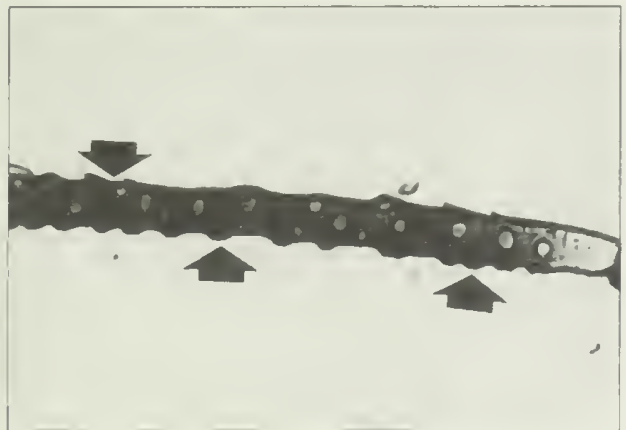

(a) sensoria

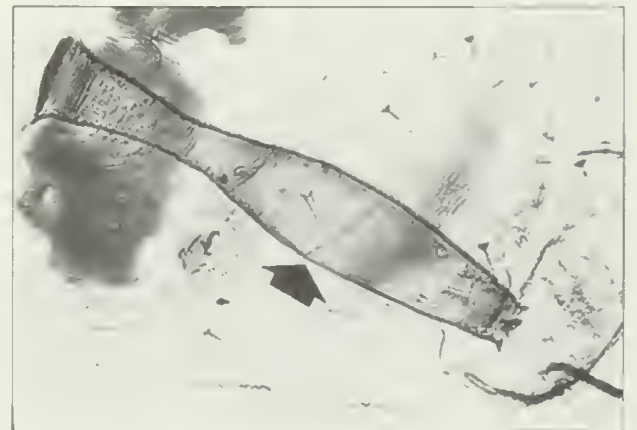

(b) siphunculus

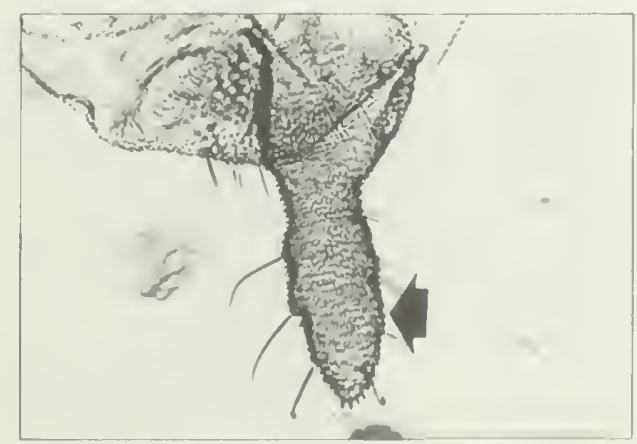

(c) callda

Antennal segment III with many sensoria: antennal segments IV and V sometimes having sensoria; antennal tubercles diverging; abdomen with large central patch; siphunculus smooth, dark, strongly swollen; cauda pale. Reference: Hille Ris Lambers 1949. 


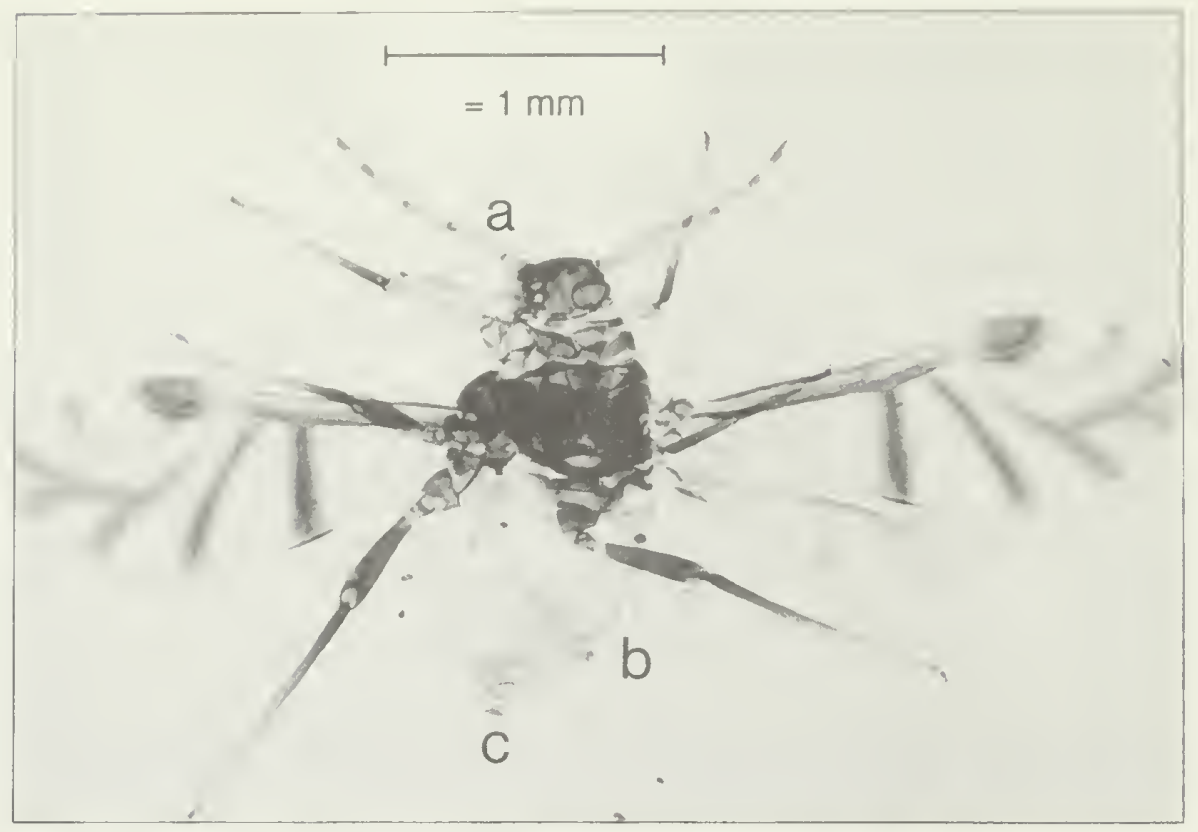

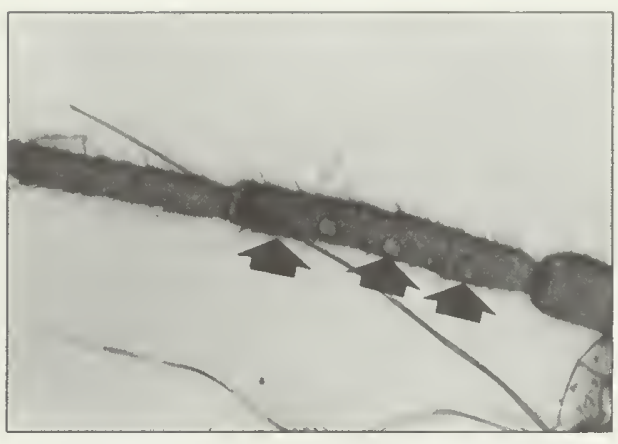

(a) sensoria

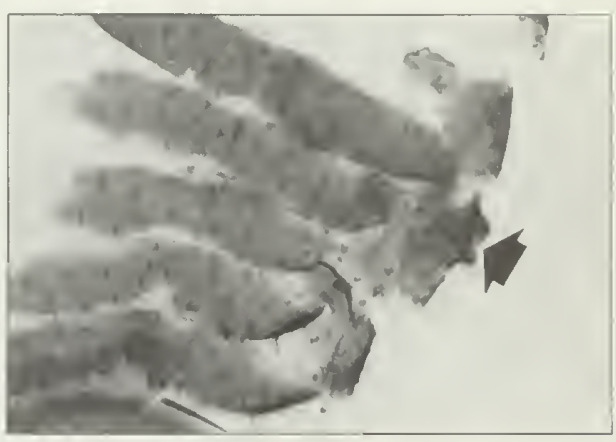

(b) siphunculus

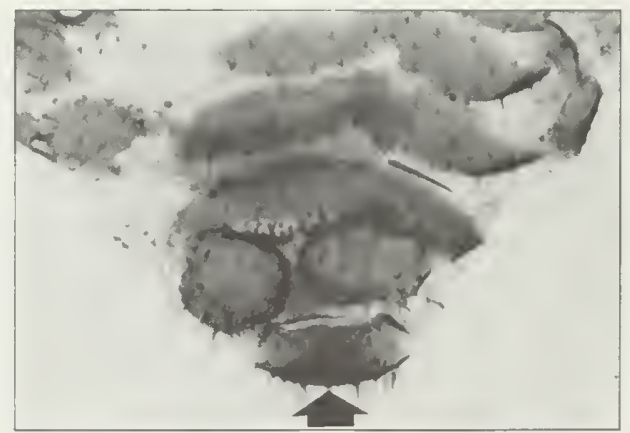

(c) cauda

Antennal segment III with sensoria; abdomen with unfused dorsal sclerites and with a transverse bar on each tergum; siphunculus small, flared apically, but without true flange; cauda semicircular; anal plate indented. Reference: Richards 1965. 


\section{Lipaphis erysimi (Kaltenbach)}

turnip aphid

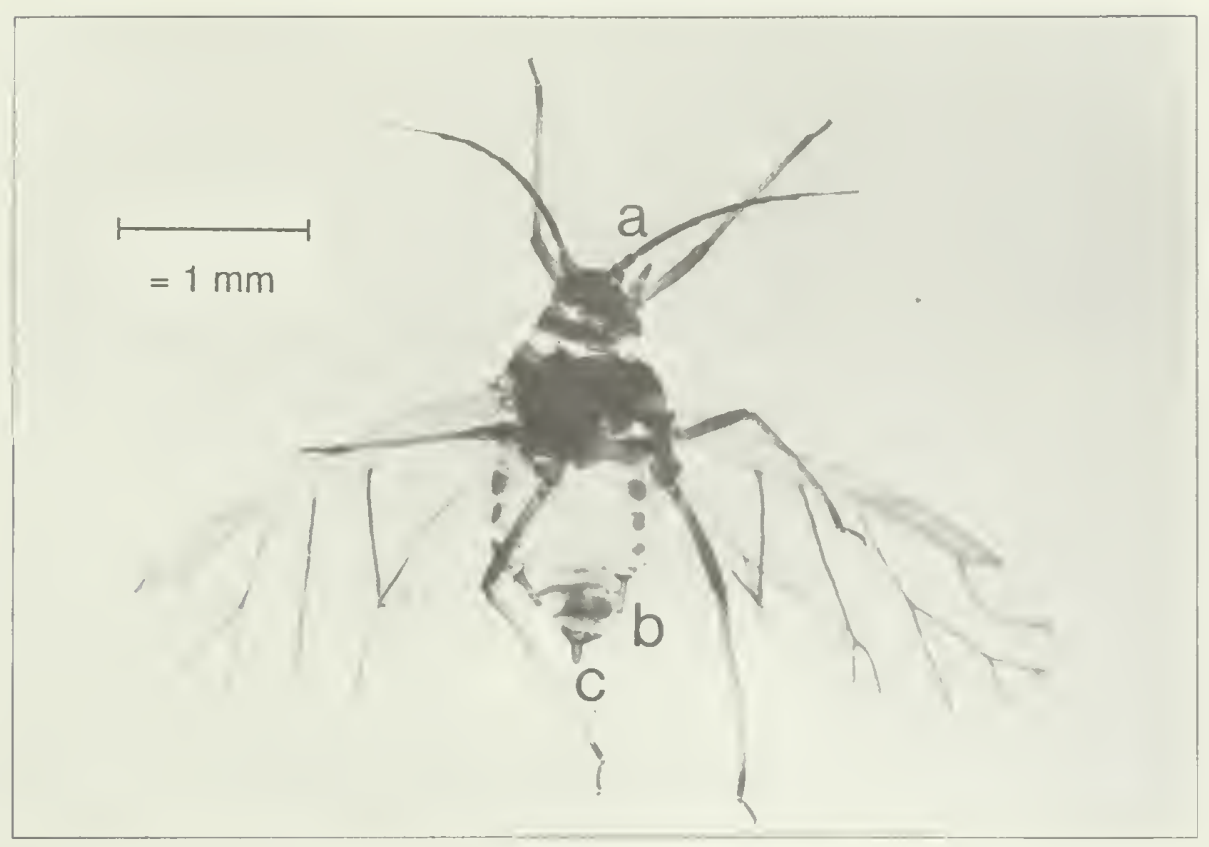

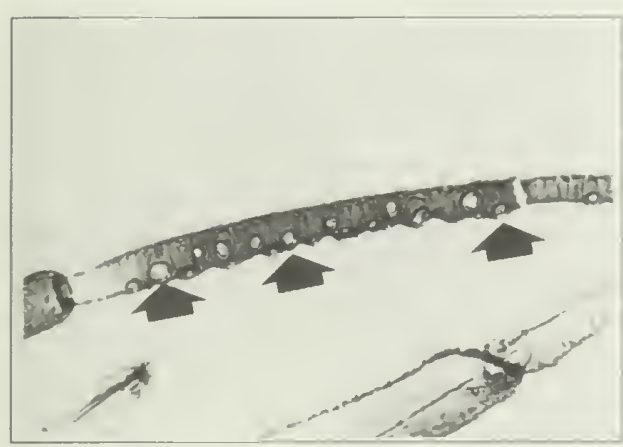

(a) sensoria

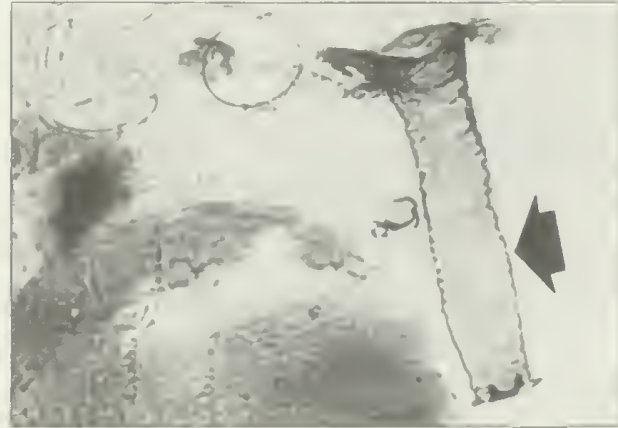

(b) siphunculus

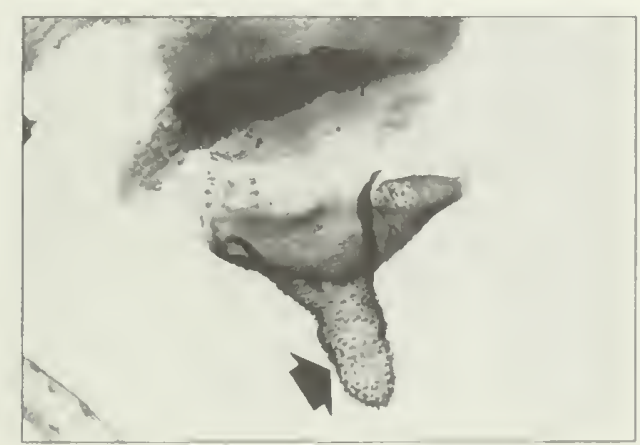

(c) caurda

Antenna shorter than body; abdomen dusky, with conspicuous. dark lateral sclerites; siphunculus lightly pigmented. "sausage"-shaped, about half as long as antennal segment III; cauda short, parallel-sided in narrower distal half; wing veins dusky. References: Blackman and Eastop 1984, Kono and Papp 1977. Taylor et al. 1984. 
Macrosiphum (Sitobion) avenae (Fabricius)

grain aphid

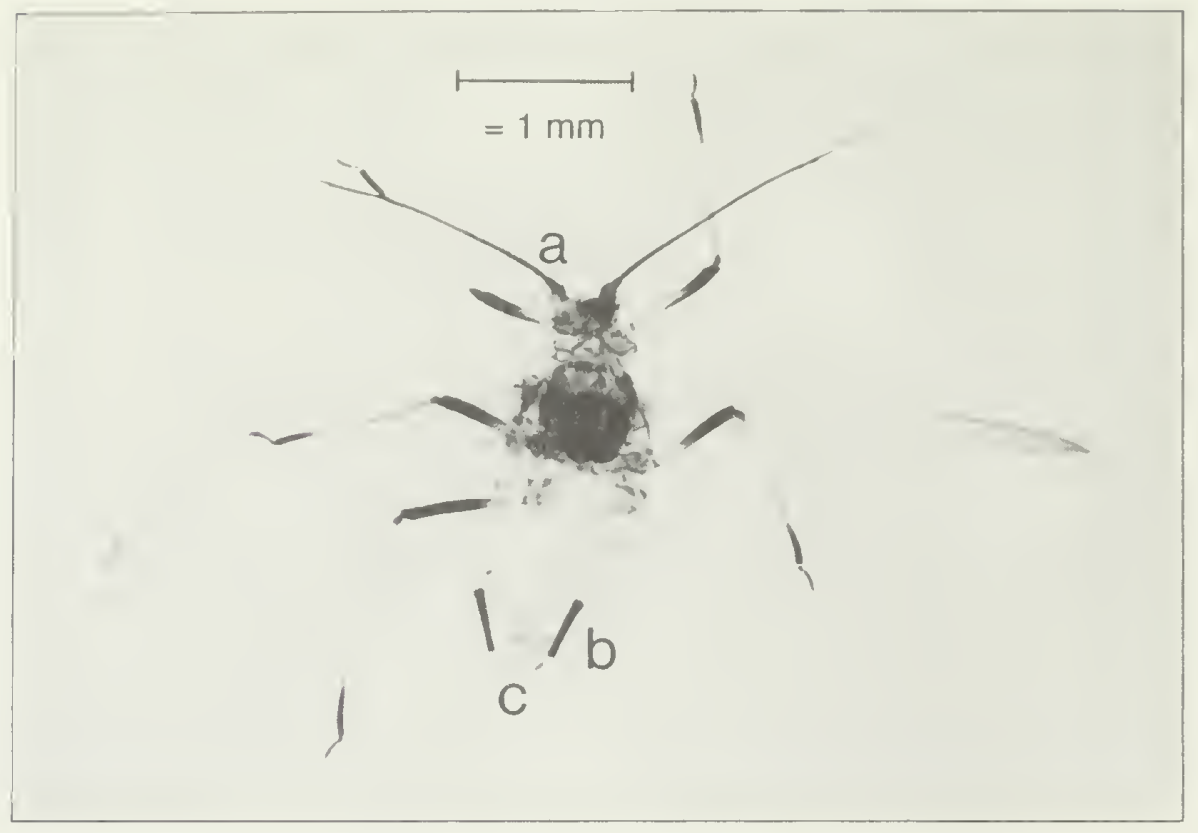

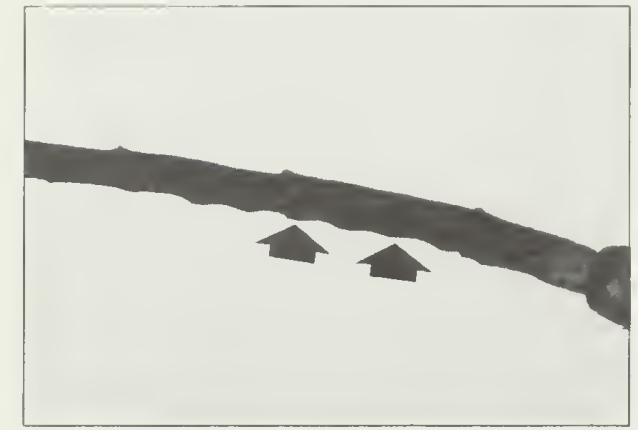

(a) sensoria

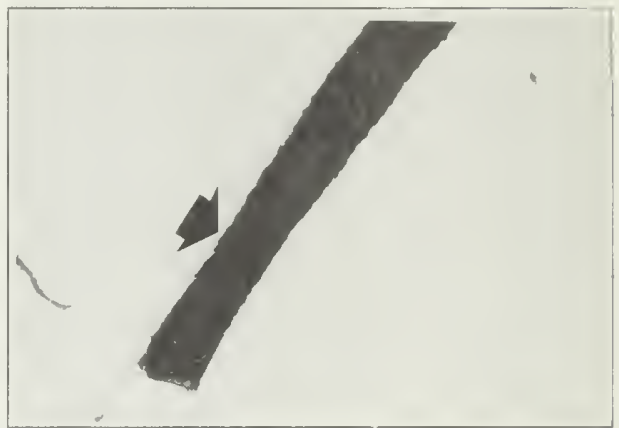

(b) siphunculus

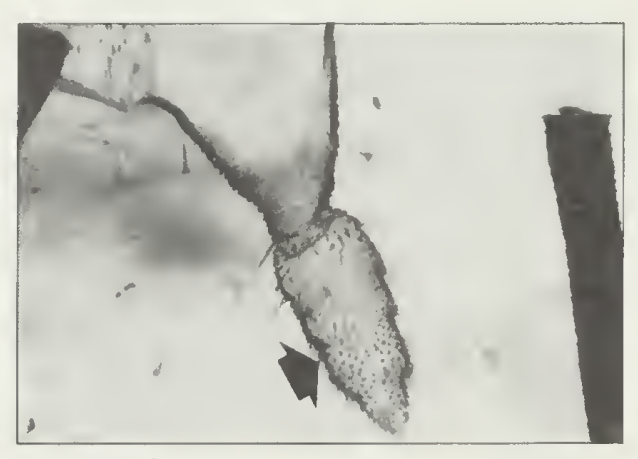

(c) cauda

Abdomen with dorsal cuticle distinctly and uniformly sclerotic, but variably pigmented; siphunculus black, long, cylindrical, reticulated distally; cauda pale, slightly shorter than siphunculus. References: Blackman and Eastop 1984, Taylor et al. 1984. 
Macrosiphum euphorbiae (Thomas)

potato aphid

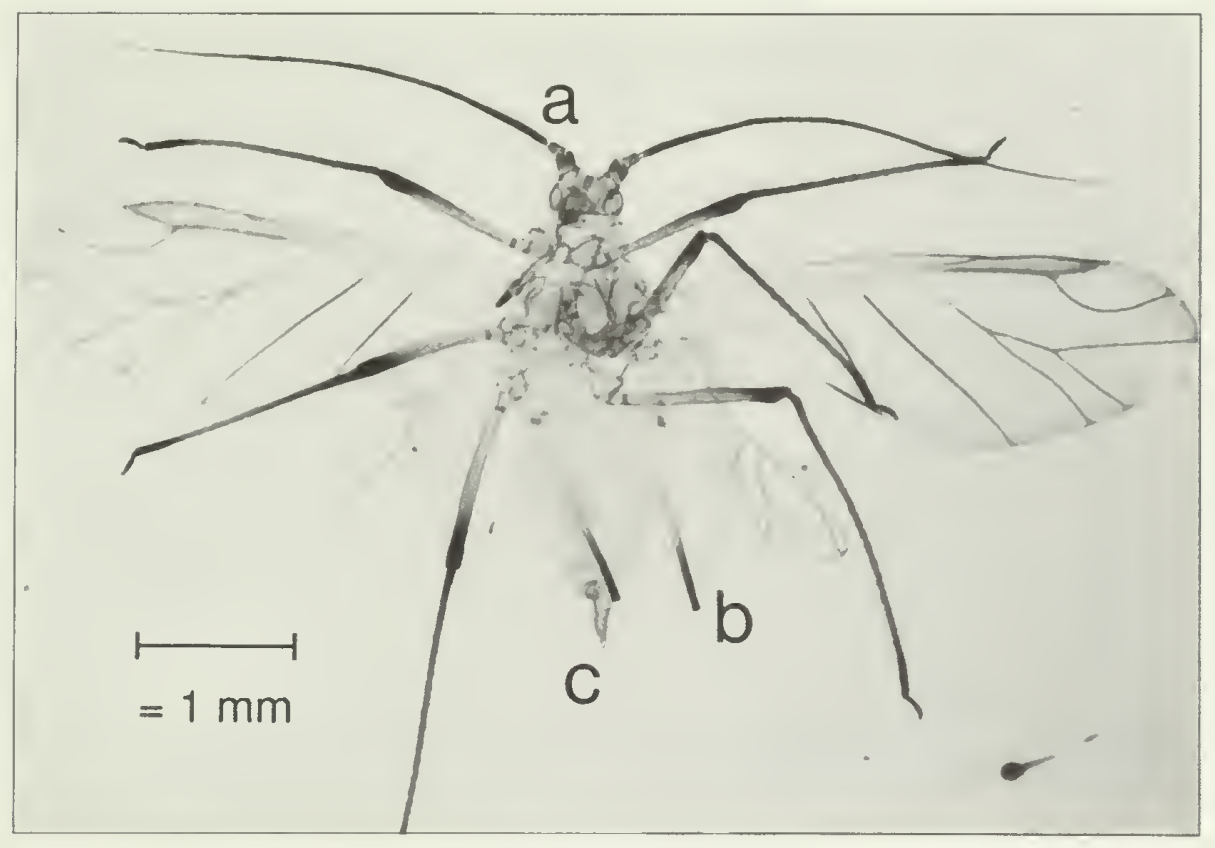

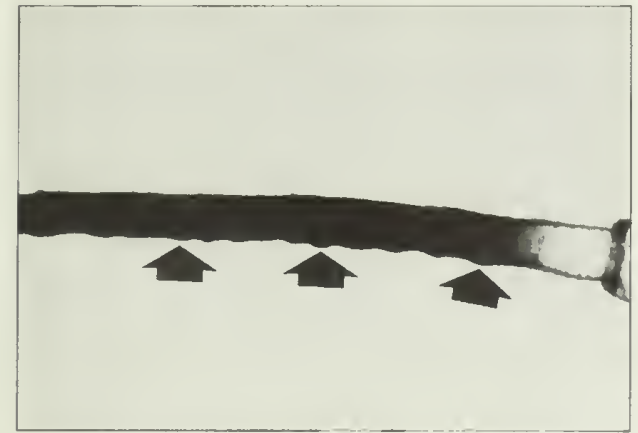

(a) sensoria

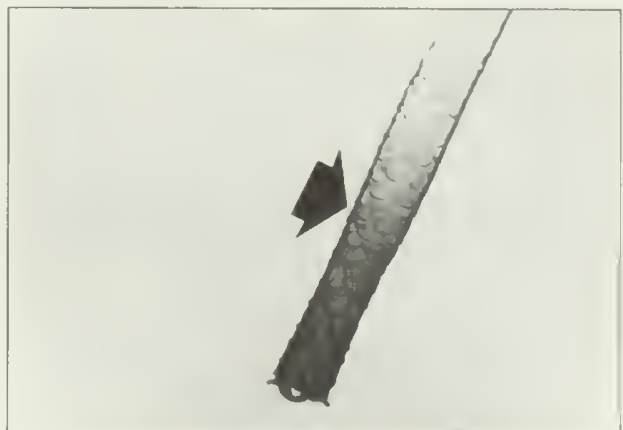

(b) siphunculus

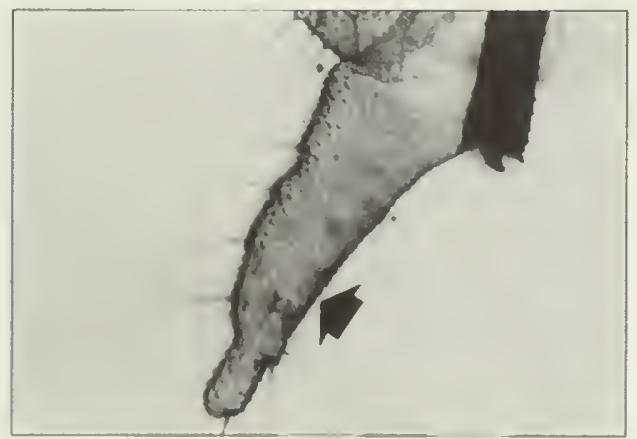

(c) cauda

Antenna pale; processus terminalis longer than antennal segment III; antennal tubercles well developed; abdomen with very light marginal sclerites: siphunculus pale proximally, dark and reticulated distally, about as long as antennal segment III; cauda long, pale, tapering; femur and tibia with dark distal ends. References: Basky 1984, Kono and Papp 1977, Taylor et al. 1984. 
Macrosiphum pallidum (Oestlund)

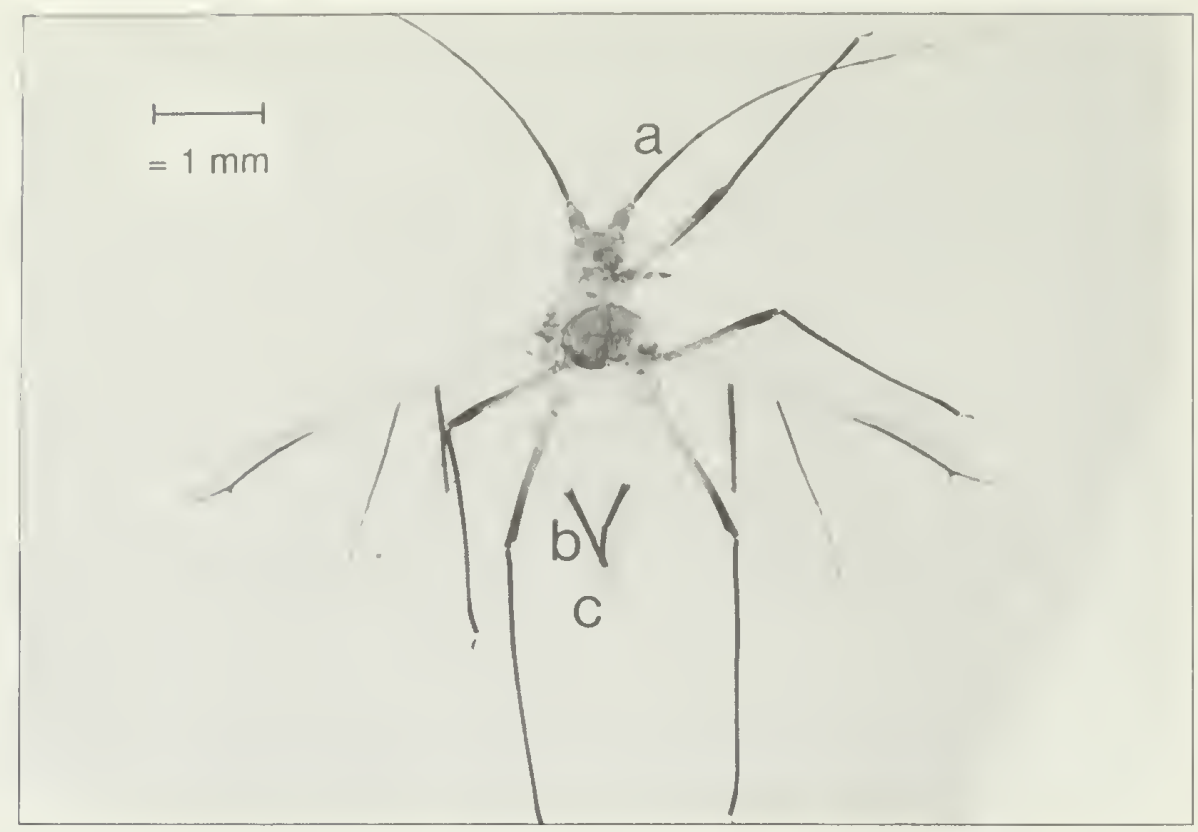

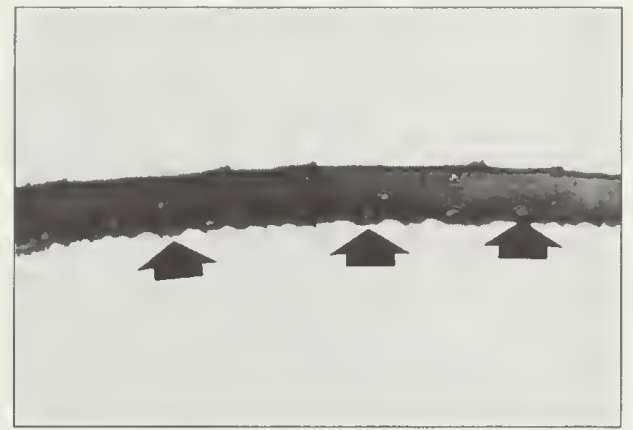

(a) sensoria

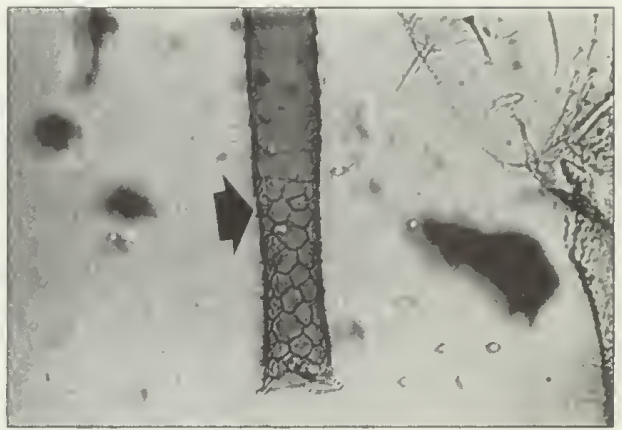

(b) siphunculus

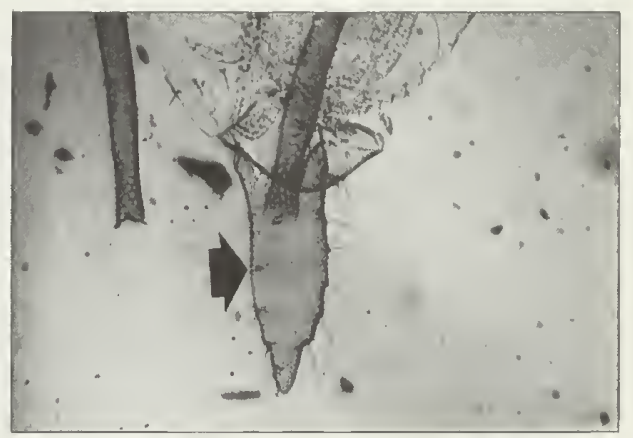

(c) caluda

Aphid medium-sized to large; antenna dark, longer than body; head and thorax dusky to dark; prothorax and abdominal terga II-V with marginal tubercles; abdomen pale to smoky, with marginal sclerites faintly visible on terga II-IV and with dorsal tubercles on terga VII and VIII; siphunculus dark, long, with reticulation; cauda elongate. References: Blackman and Eastop 1984, MacGillivray 1968. 


\section{Mindarus abietinus Koch}

balsam twig aphid
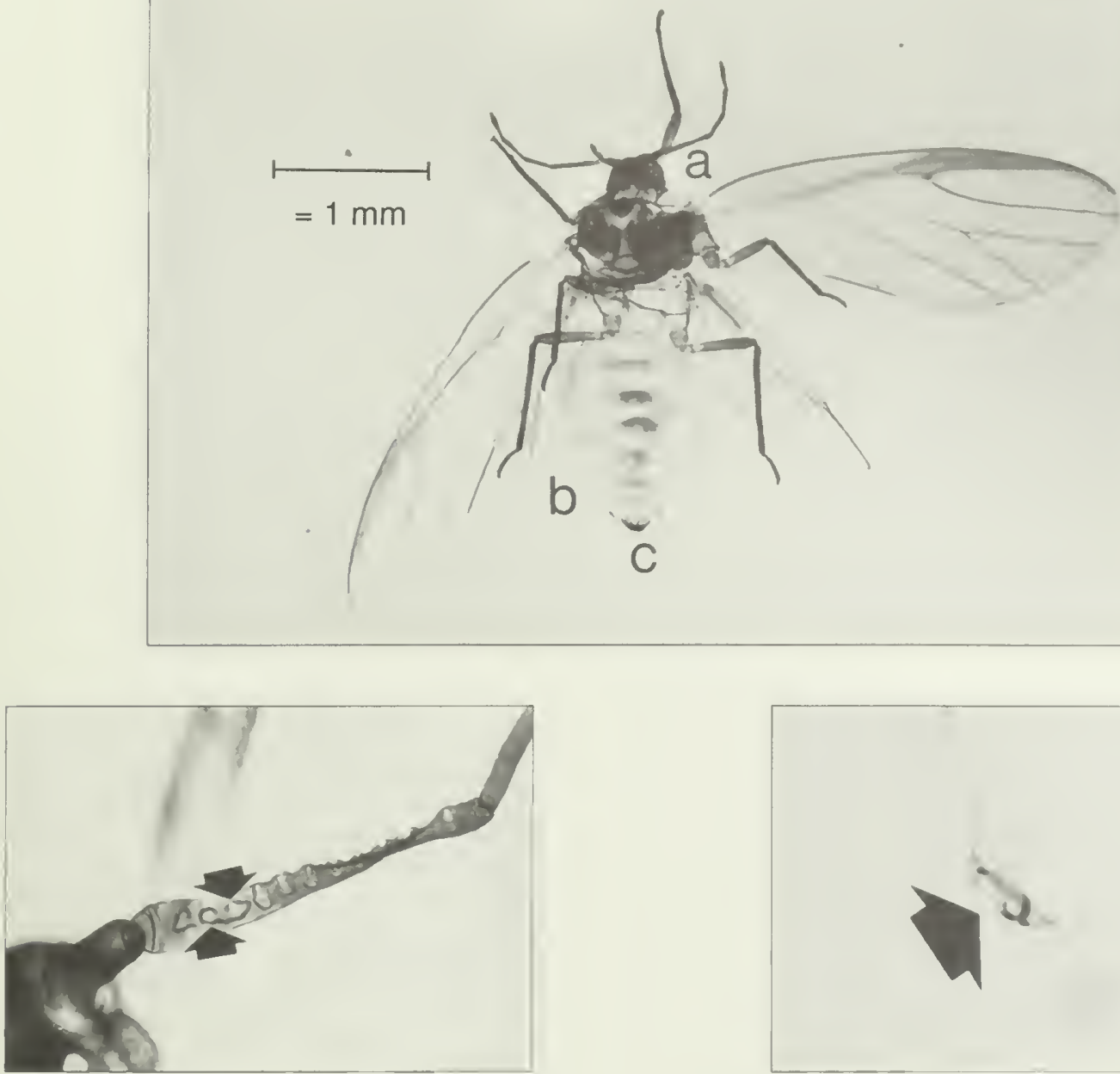

(a) sensoria

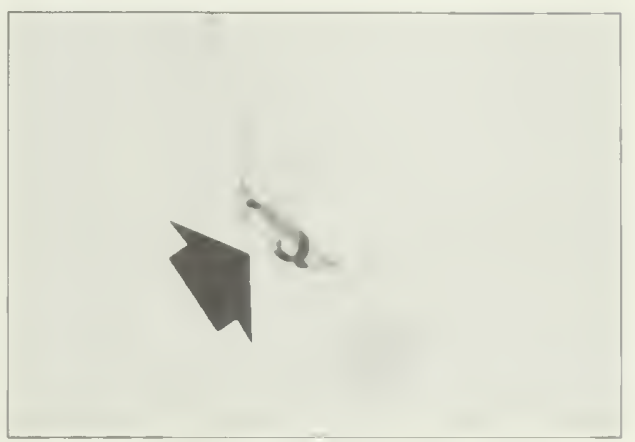

(b) siphunculus

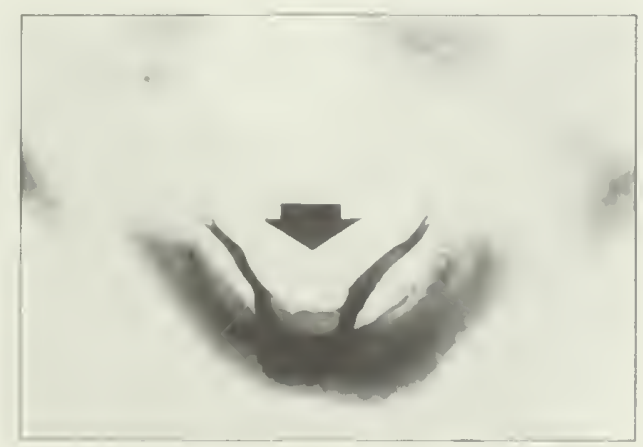

(c) cauda

Abdomen with dark, transverse bands and marginal spots; siphunculus present as a pore; cauda short, tongue-shaped; anal plate entire; fore wing with media that is usually 1 -forked; radial sector starting at base of very long, narrow, curved. pointed pterostigma that continues to apex of wing. Reference: Heic 1980. 


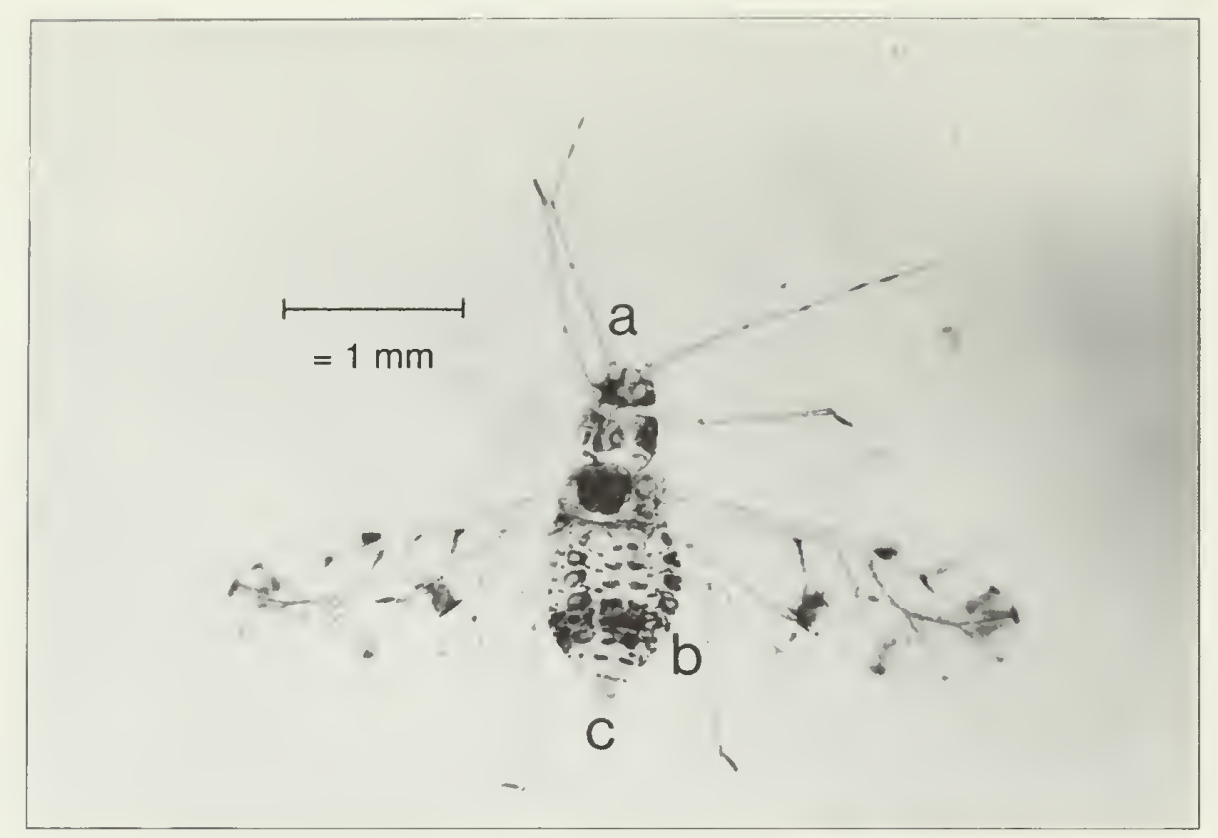

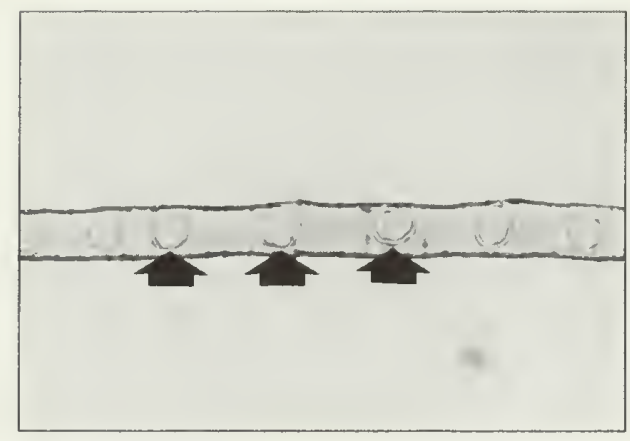

(a) sensoria

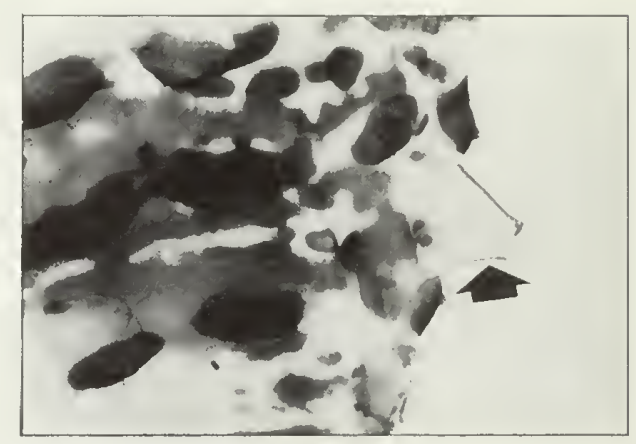

(b) siphunculus

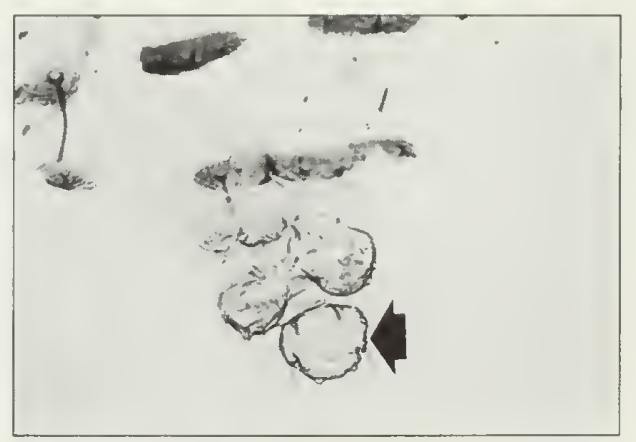

(c) cauda

Antennal segments III-V and base of segment VI with dark rings at apices; siphunculus short; cauda knobbed; anal plate deeply indented. The immaculate form (aphid yellow, with wing veins and antennal segments black at apices), occurs in Ontario in June, occasionally in July; the melanistic form (body with dark markings and infuscated wings) occurs occasionally early in the season, but is the only form that occurs later in the season. Reference: Richards 1965. 


\section{Myzus persicae (Sulzer)}

green peach aphid

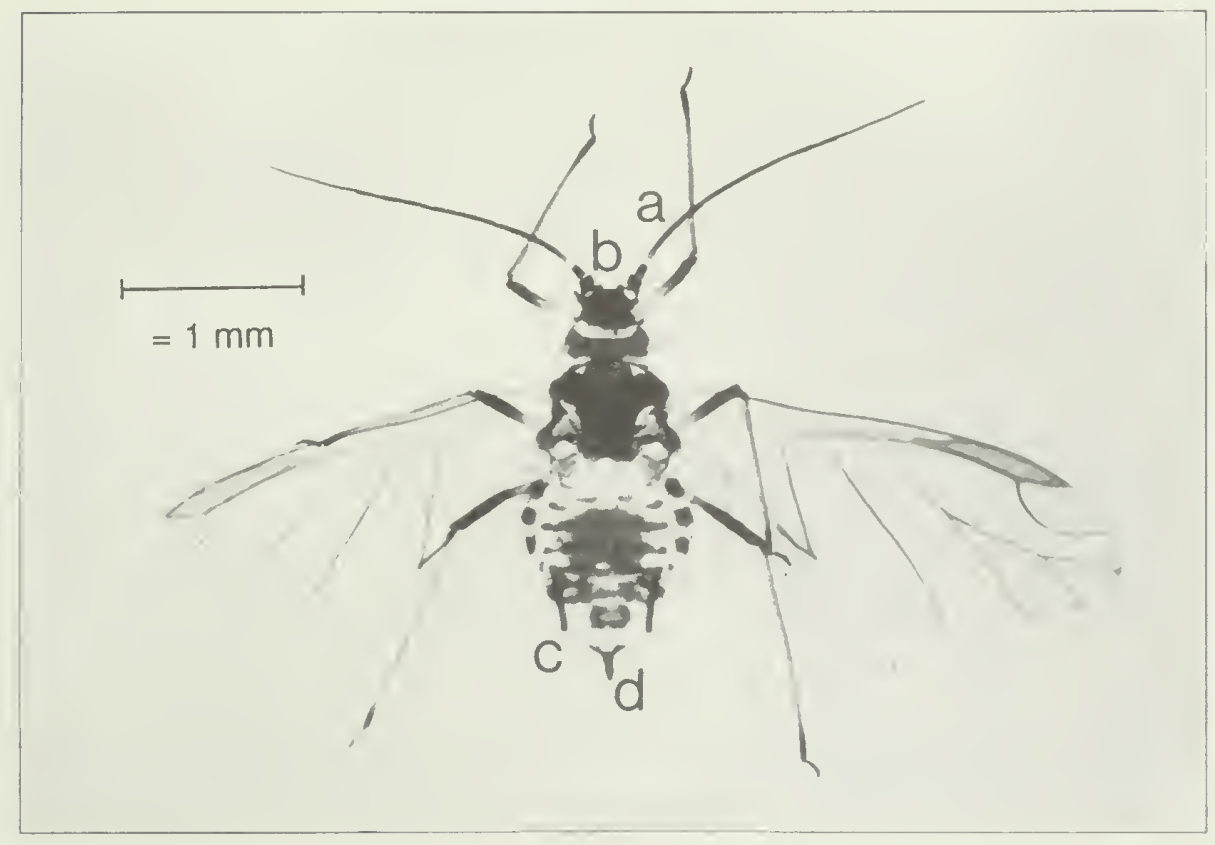

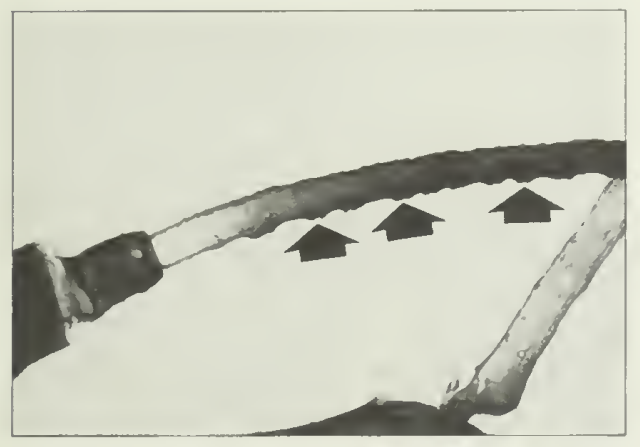

(a) sensoria

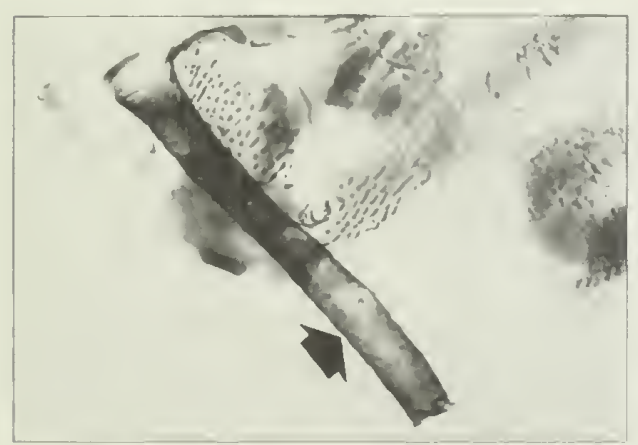

(c) siphunculus

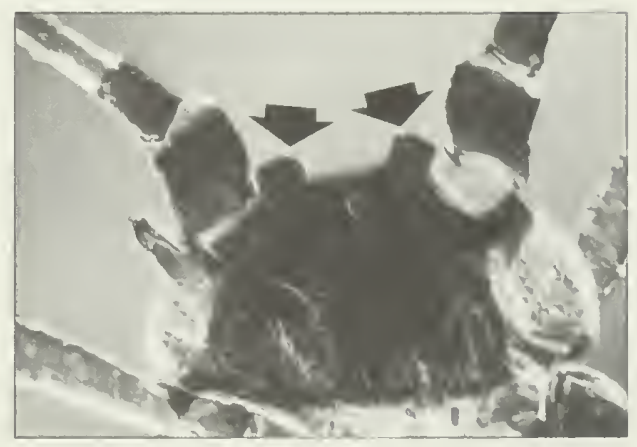

(b) antenual tubercles

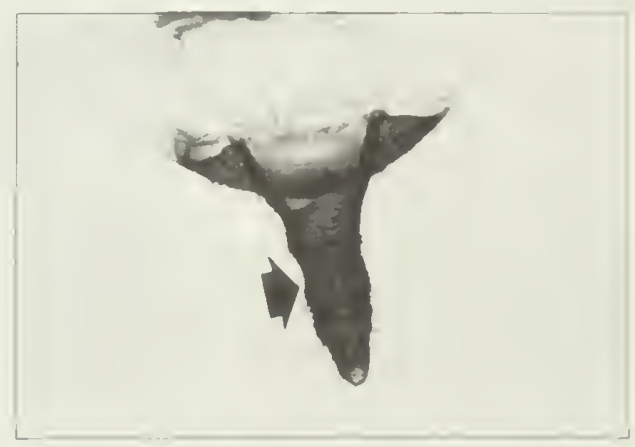

(d) cauda

Antennal segment III with 10-15 sensoria; processus terminalis at least twice as long as base of antennal segment VI; antennal tubercles very prominent and inward-pointing; abdomen with distinct. dark dorsal patch that is irregular-sided with a clear "window" toward posterior edge: siphunculus cylindrical to slightly swollen distally, more than twice as long as cauda; cauda slightly constricted at middle; wing veins pale. References: Kono and Papp 1977. McLeod and Lowery 1989, Medler and Ghosh 1969. 


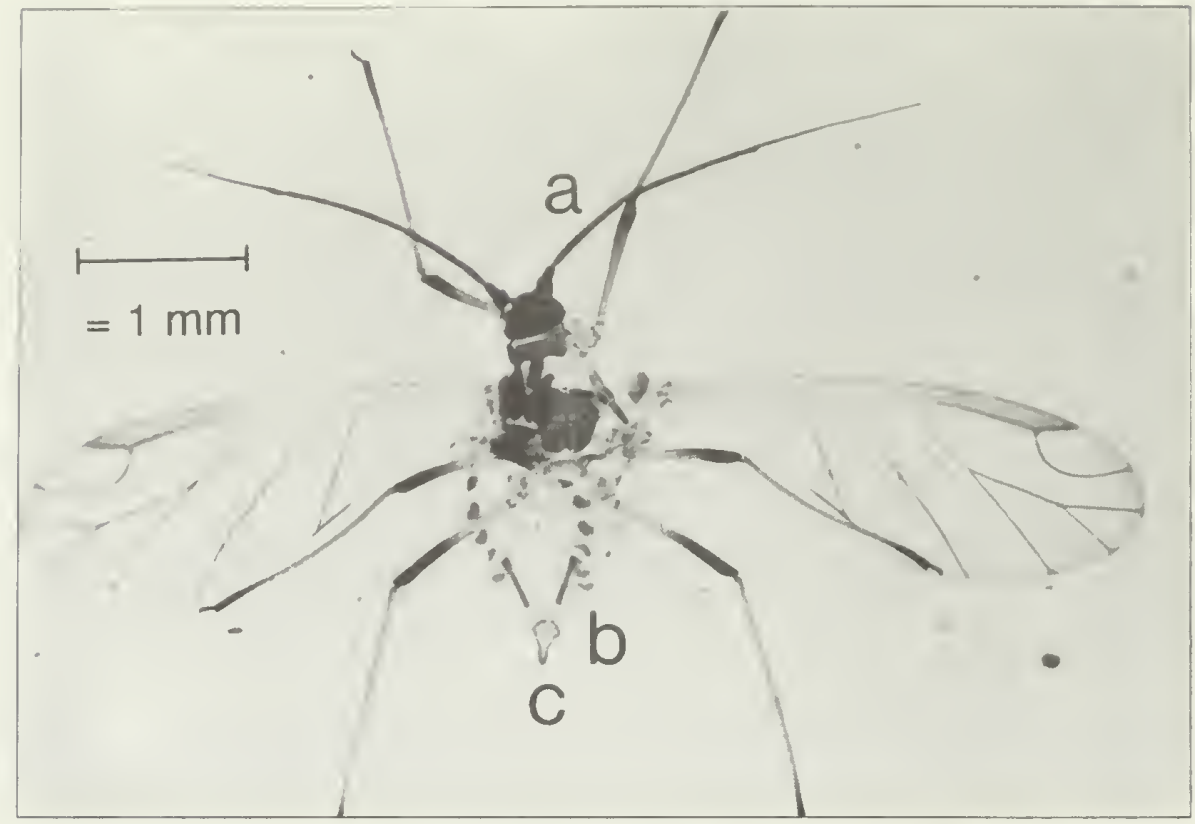

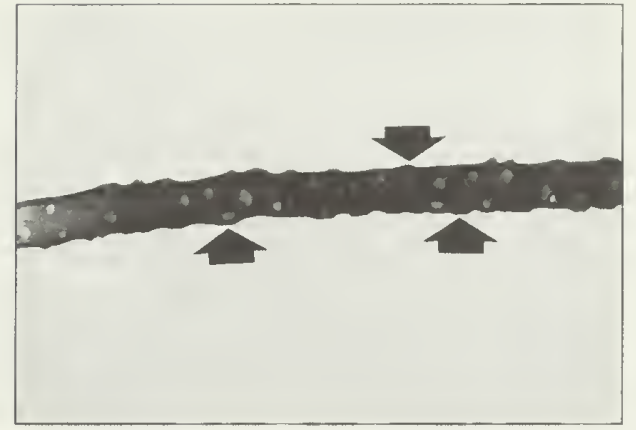

(a) sensoria

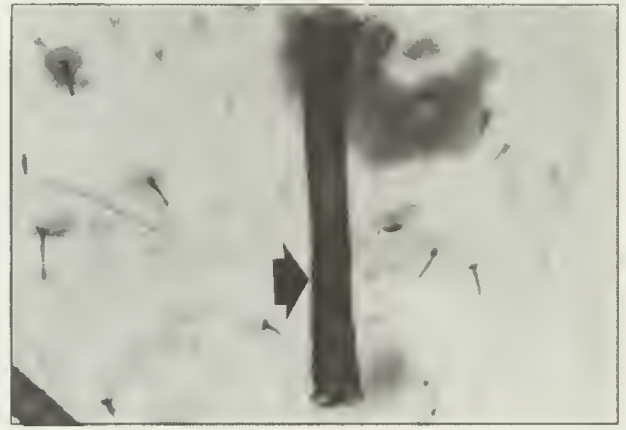

(b) siphunculus

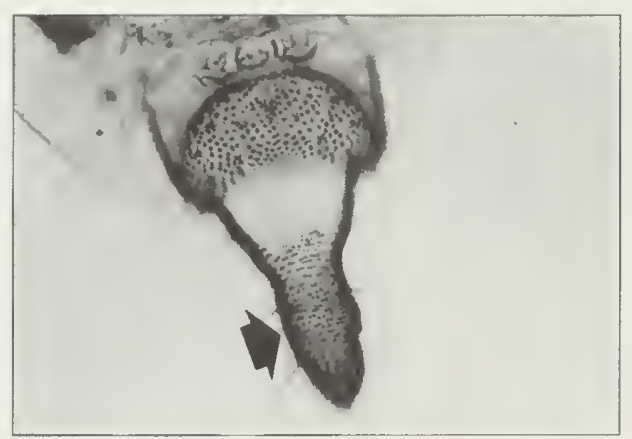

(c) cauda

Species having wide range of morphological variation; antenna dark; antennal segment III with pale base; abdomen pale, with dark marginal and small intersegmental sclerites; abdomen with dorsal sclerites or crossbars sometimes present and sometimes forming a central patch; siphunculus dark distally; cauda pale, dusky, or brownish; legs dark, with femur, tibia, and tarsus having darker tips. References: Blackman and Eastop 1984, Heie 1979. 
currant-lettuce aphid

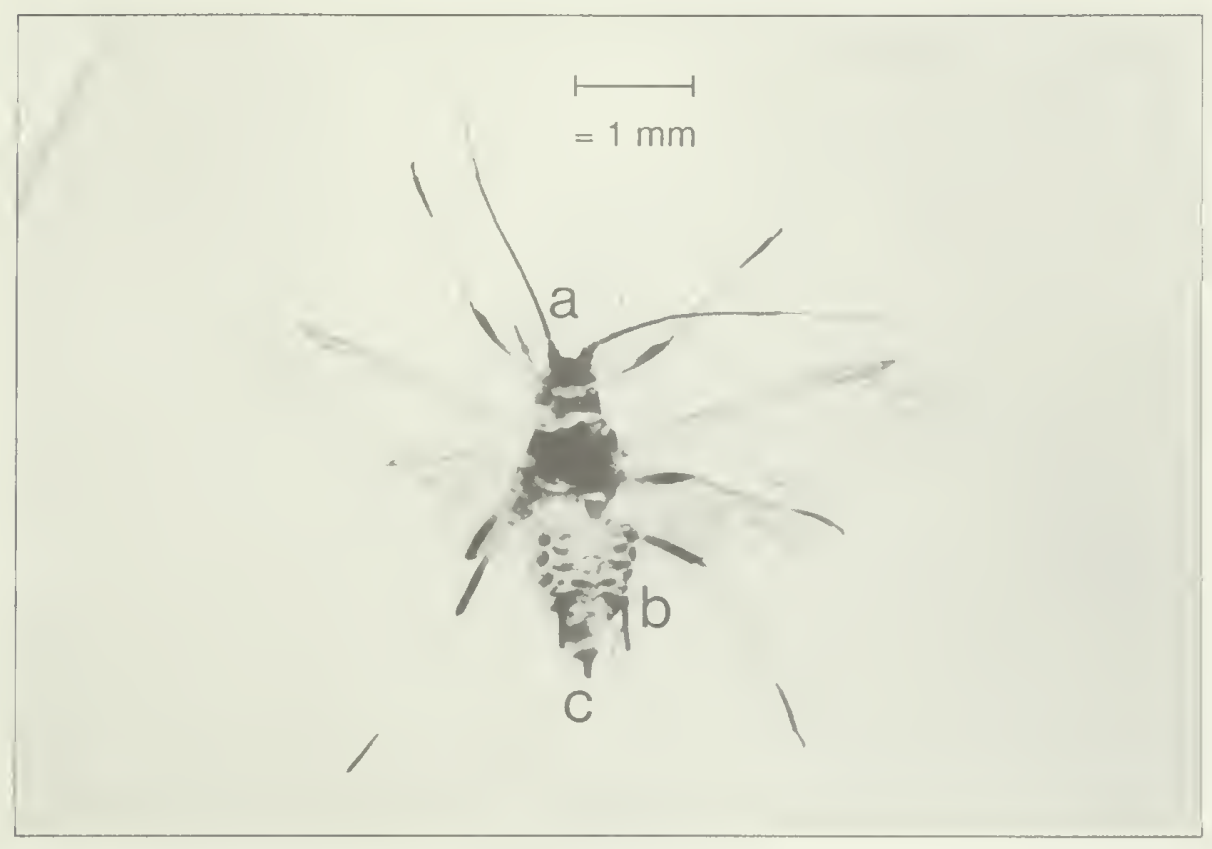

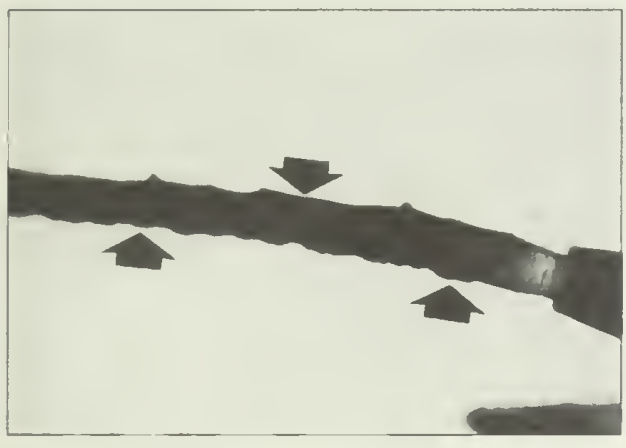

(a) sensoria

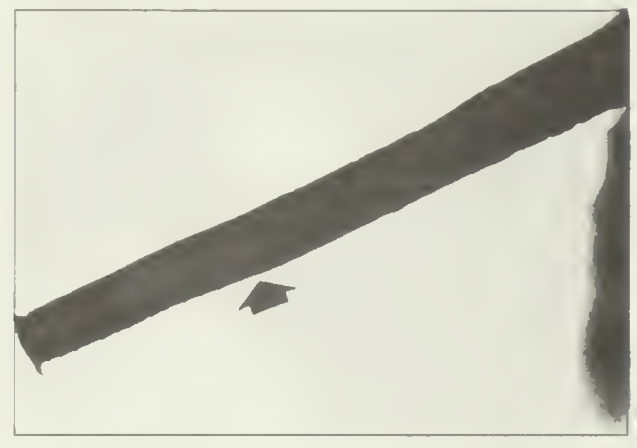

(b) siphunculus

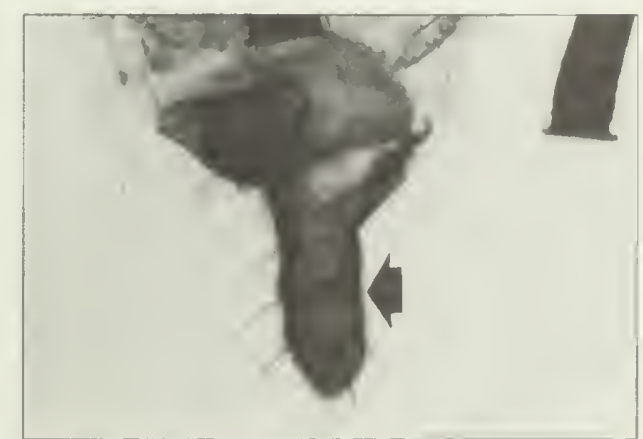

(c) cauda

Antenna dark; antennal segment III with 30-38 sensoria: antennal segment IV with 5-12 sensoria; abdomen with pale to dark irregular flecks and stripes that sometimes form a patch; siphunculus straight. dark, not reticulated: cauda dark. elongate; leg joints dark. Reference: Taylor et al. 1984. 
Nearctaphis bakeri (Cowen)

clover aphid

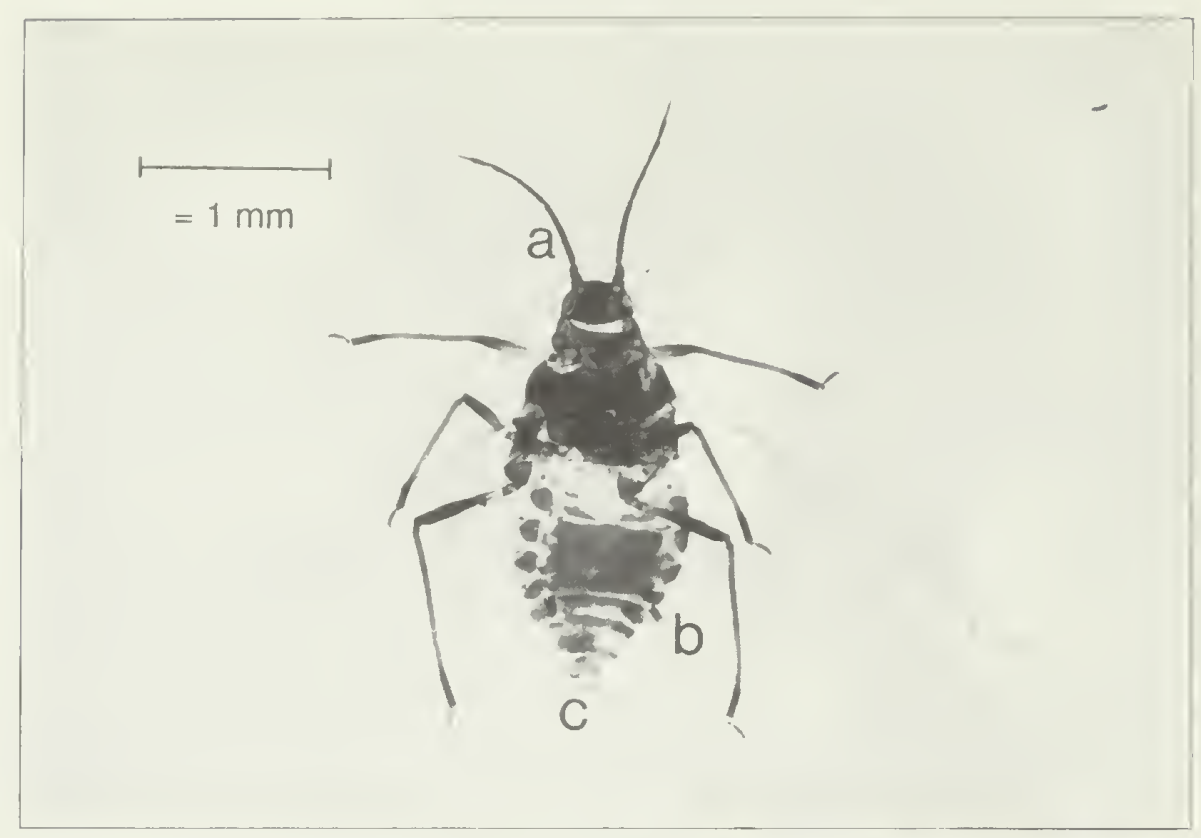

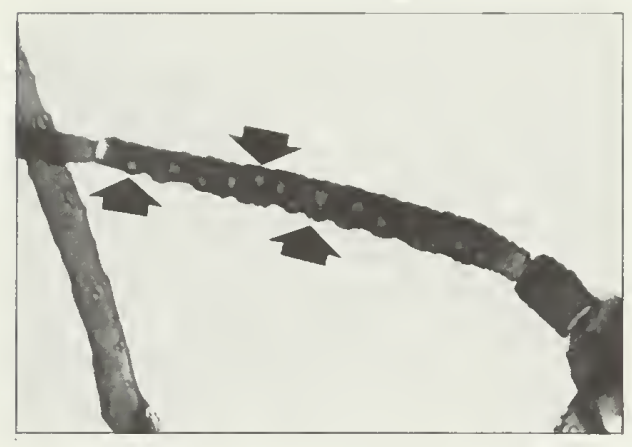

(a) sensoria

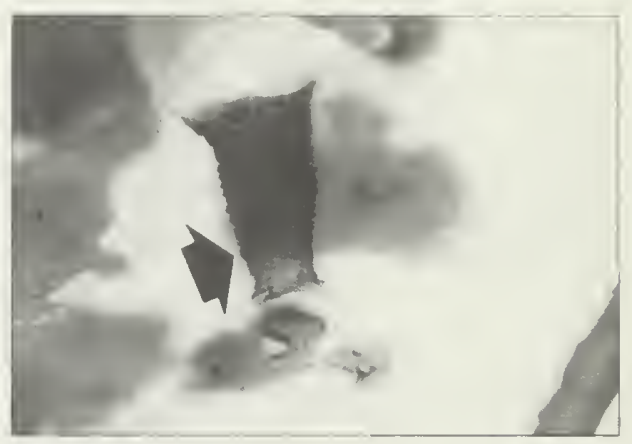

(b) siphuncuhus

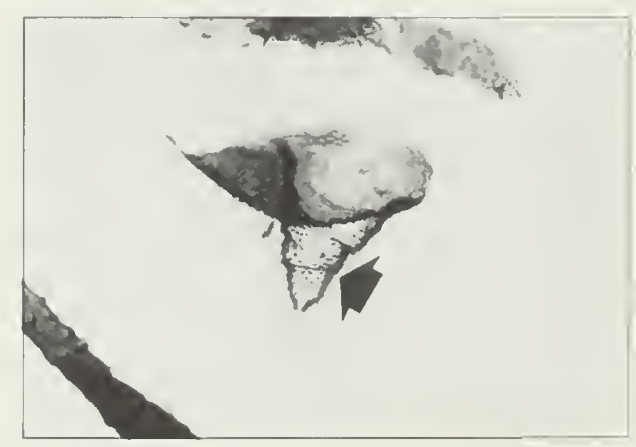

(c) cauda

Antennal segment III with more than 10 sensoria; head and thorax black; abdomen with dark dorsal patch and lateral tubercles; siphunculus short, cylindrical, or slightly tapering, with denticulate imbrications and distinct flange; cauda short, pointed. References: Blackman and Eastop 1984, Palmer 1952, Taylor et al. 1984. 


\section{Nearctaphis crataegifoliae (Fitch)}

long-beaked clover aphid

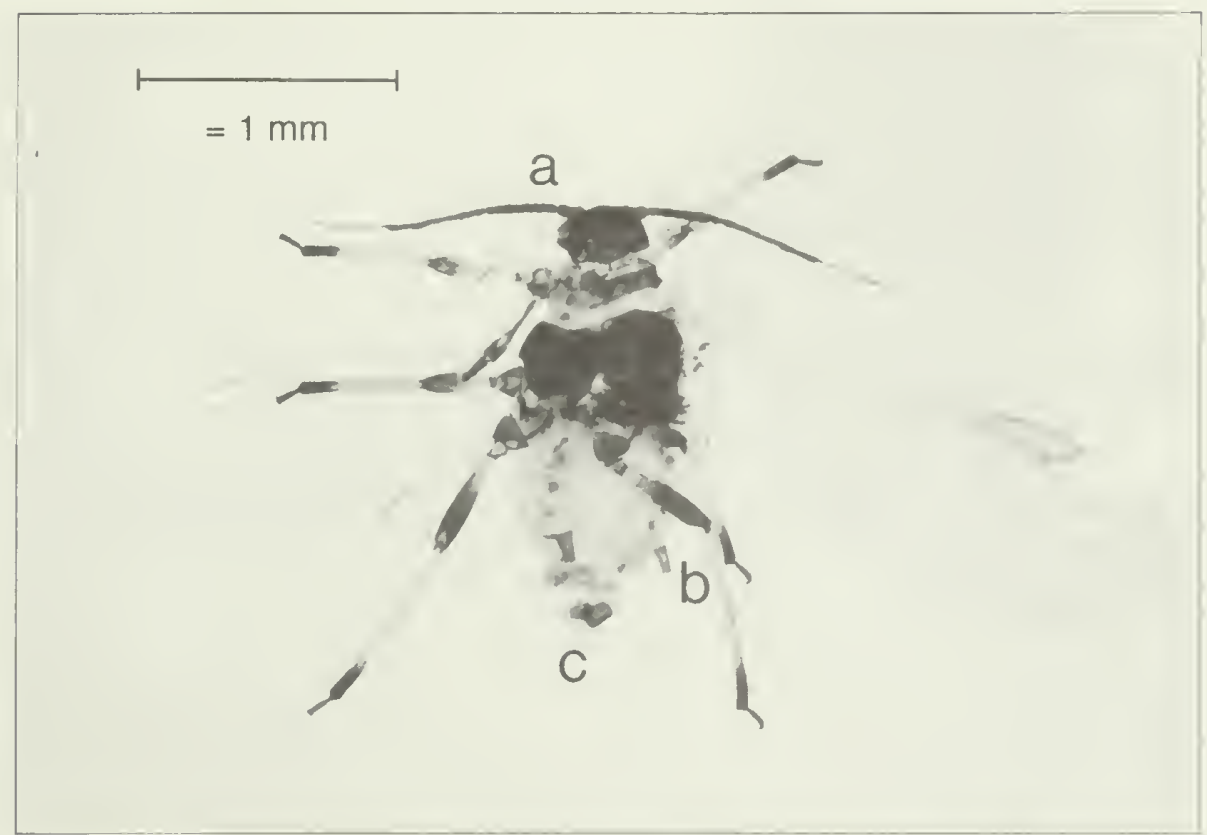

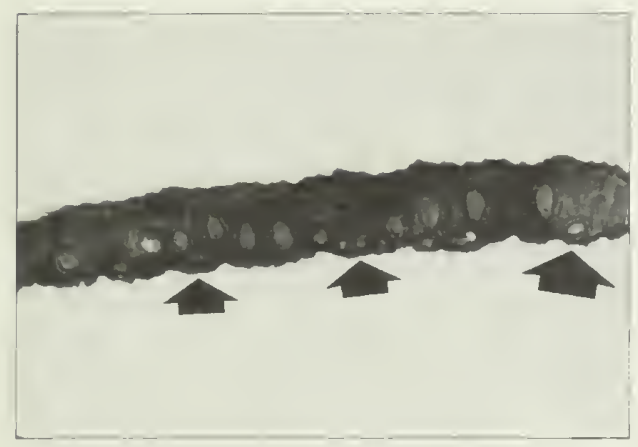

(a) sensoria

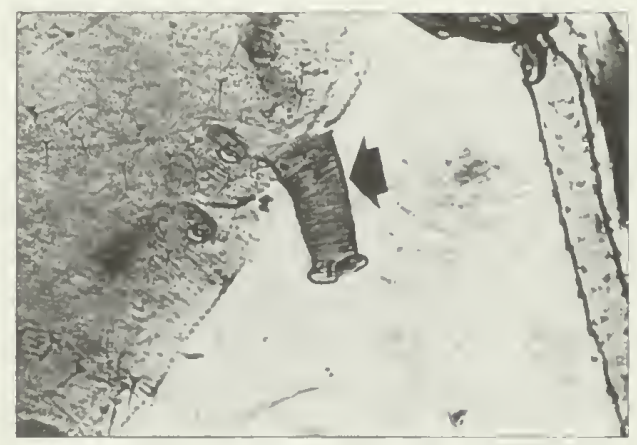

(b) siphunculus

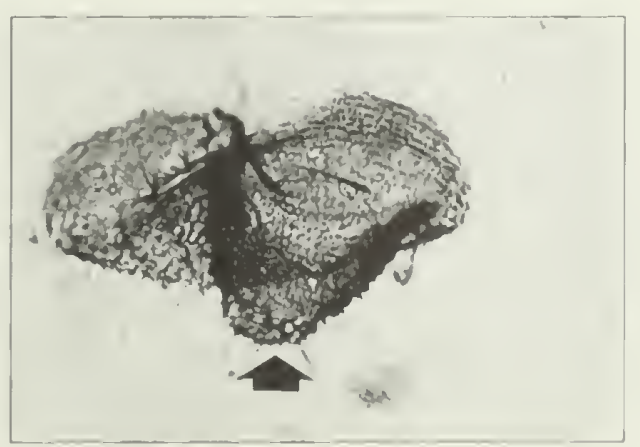

(c) canda

Abdomen colorless; abdominal tergum VIII with brown lateral selerites and brown, transverse bar; siphunculus imbricated, about as long as apical hind tarsal segment, and having flange: cauda bluntly triangular. without preapical constriction. Reference: Richards 1969. 

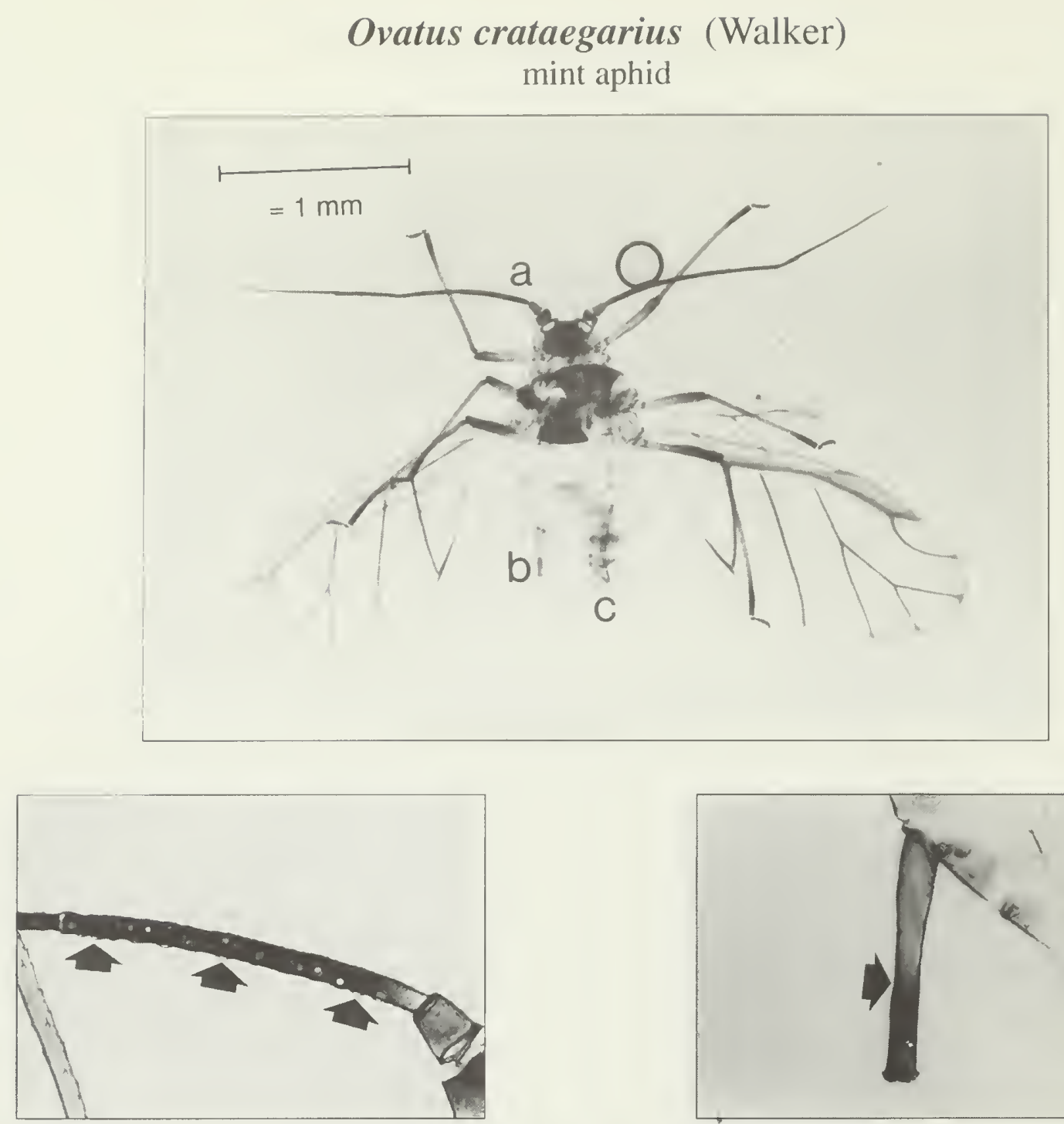

(a) sensoria

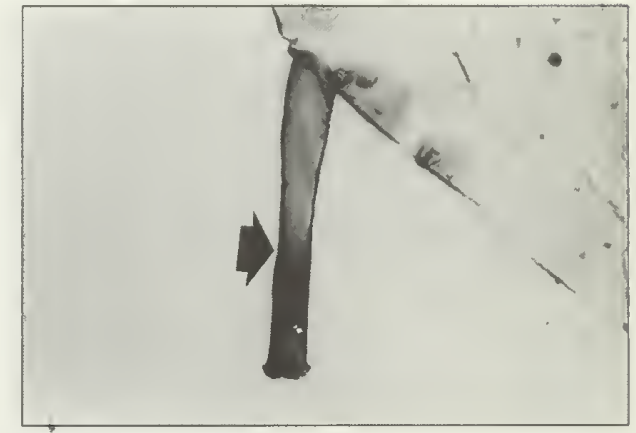

(b) siphunculus

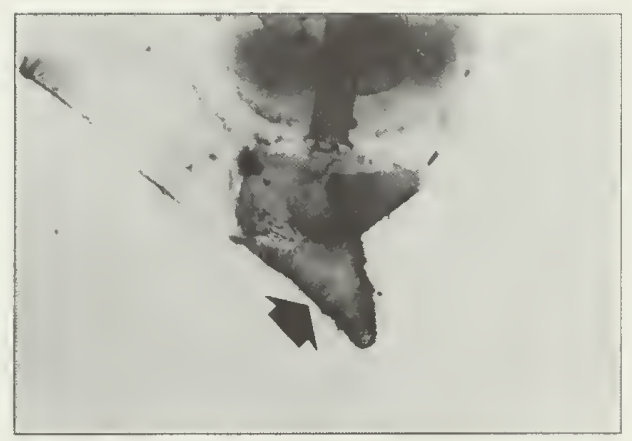

(c) cauda

Antennal segment III with 23-30 sensoria; processus terminalis long; abdomen pale, without black dorsal markings, but with light marginal sclerites; siphunculus cylindrical, medium-pigmented; cauda triangular; wing veins dark. References: Blackman and Eastop 1984, Taylor et al. 1984. 


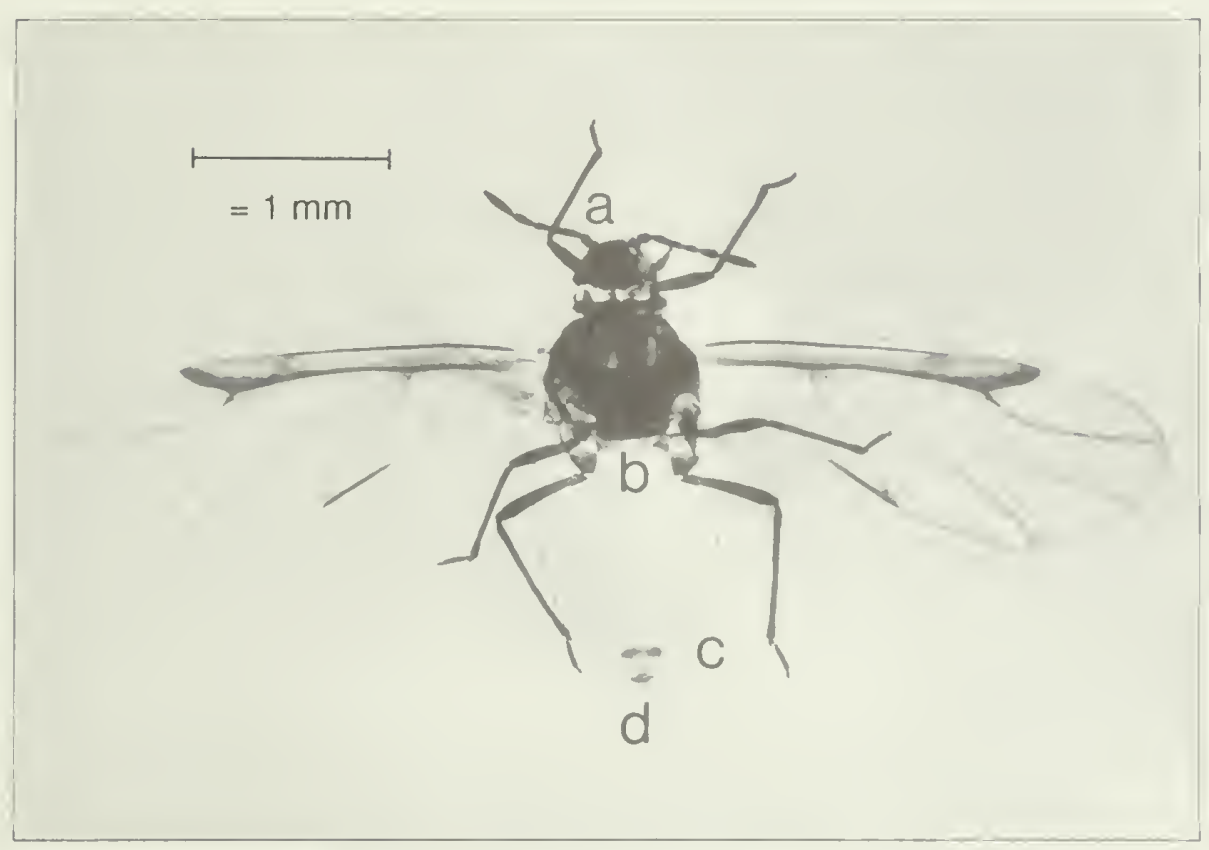

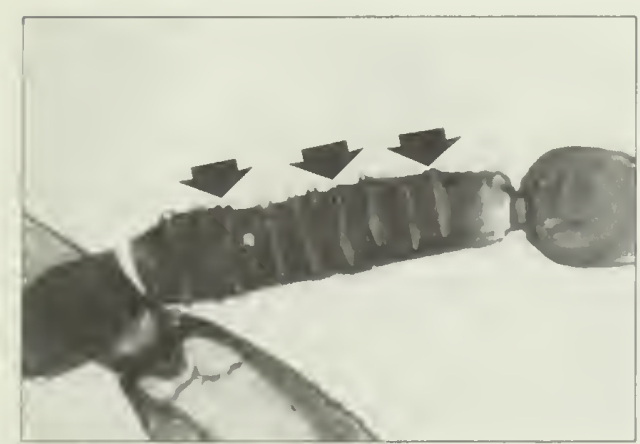

(a) sensoria

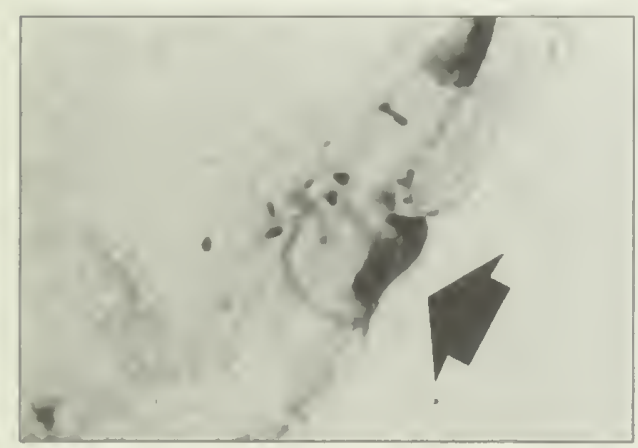

(c) siphunculus

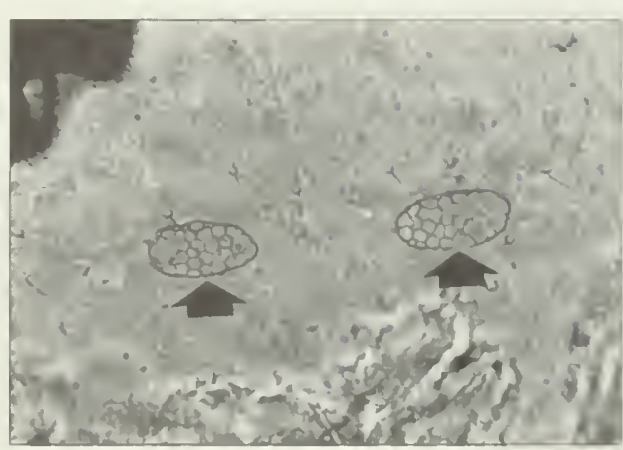

(b) wax plates

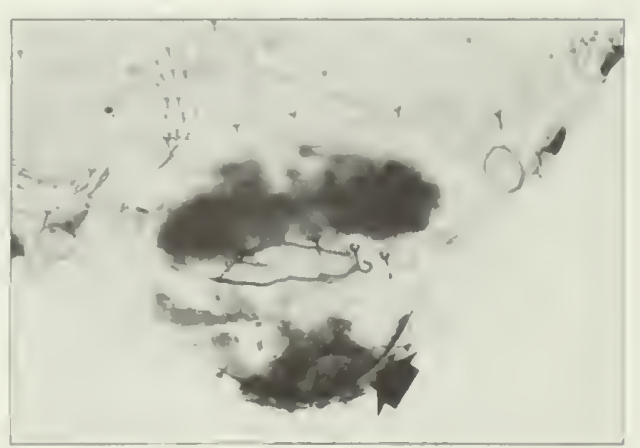

(d) cauda

Aphid small to medium-sized; antennal segments III and IV with transverse. narrow sensoria; siphunculus consisting of a mere rim; cauda semilunar; fore wing with unbranched media. References: Heie 1980. Kono and Papp 1977. Palmer 1952. 


\section{Periphyllus lyropictus (Kessler)}

Norway maple aphid

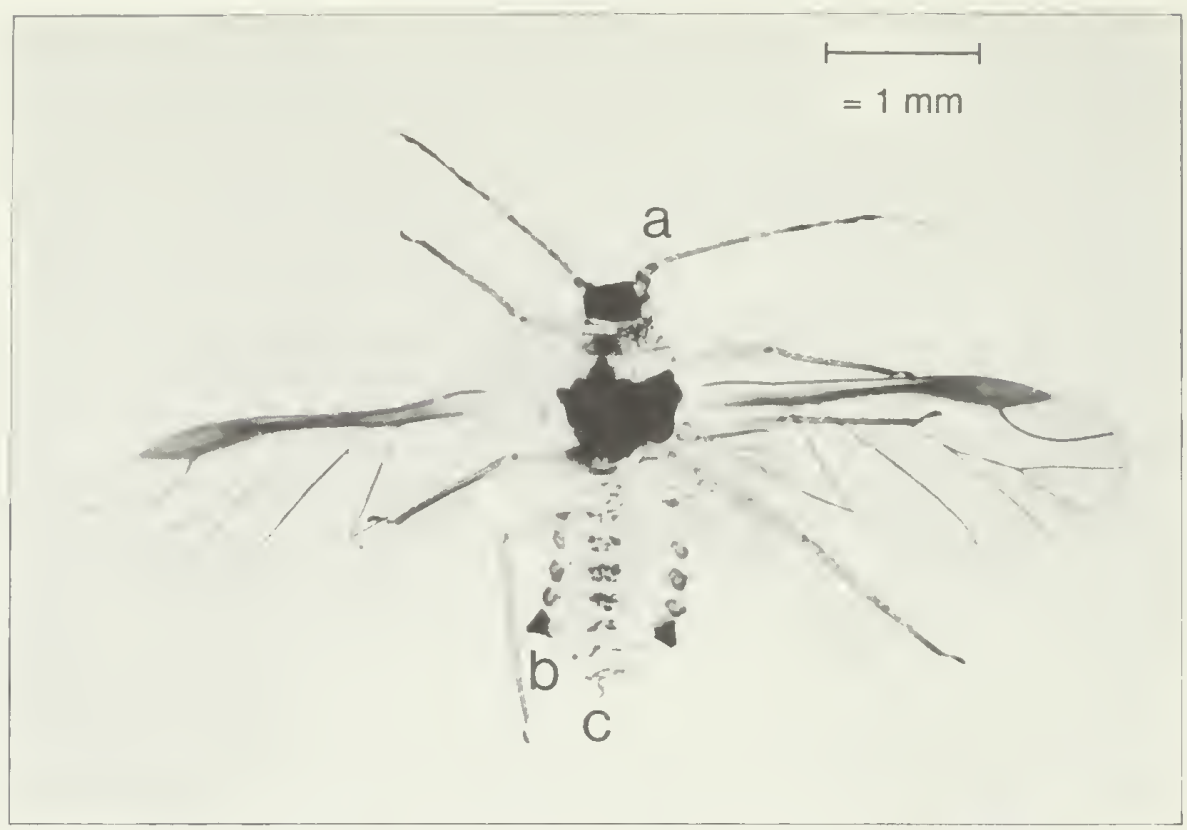

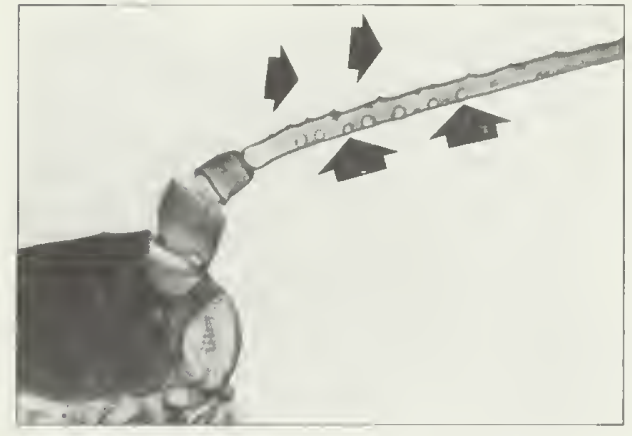

(a) sensoria and setae

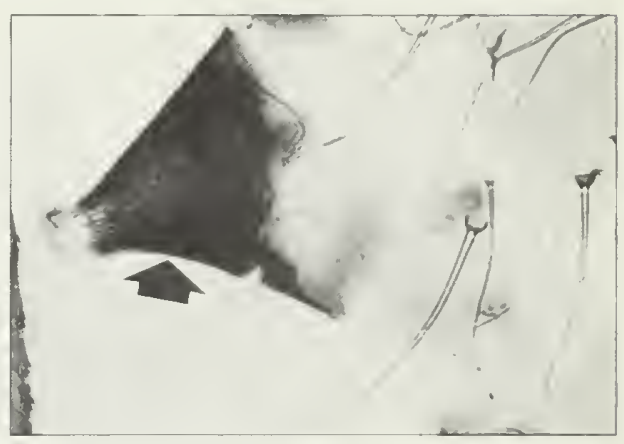

(b) siphunculus

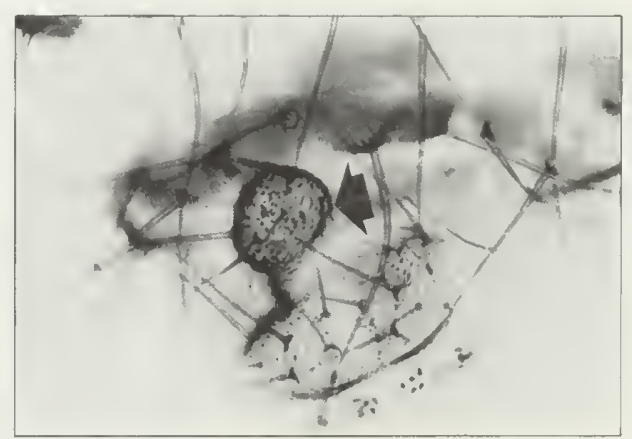

(c) cauda

Antennal segments III, IV, and base of V pale and mottled with darker areas; antennal setae long, pointed; abdomen with brown lateral sclerites; abdominal terga I-VI with small, irregular, square, brown patches; tergum VII usually with pair of brown spots; tergum VIII with narrow, transverse bar; siphunculus reticulated for most of its length; cauda rounded; anal plate entire; legs pale, with tibia and tarsus having darker tips. Reference: Richards 1972. 


\section{Pleotrichophorus sp. Börner}

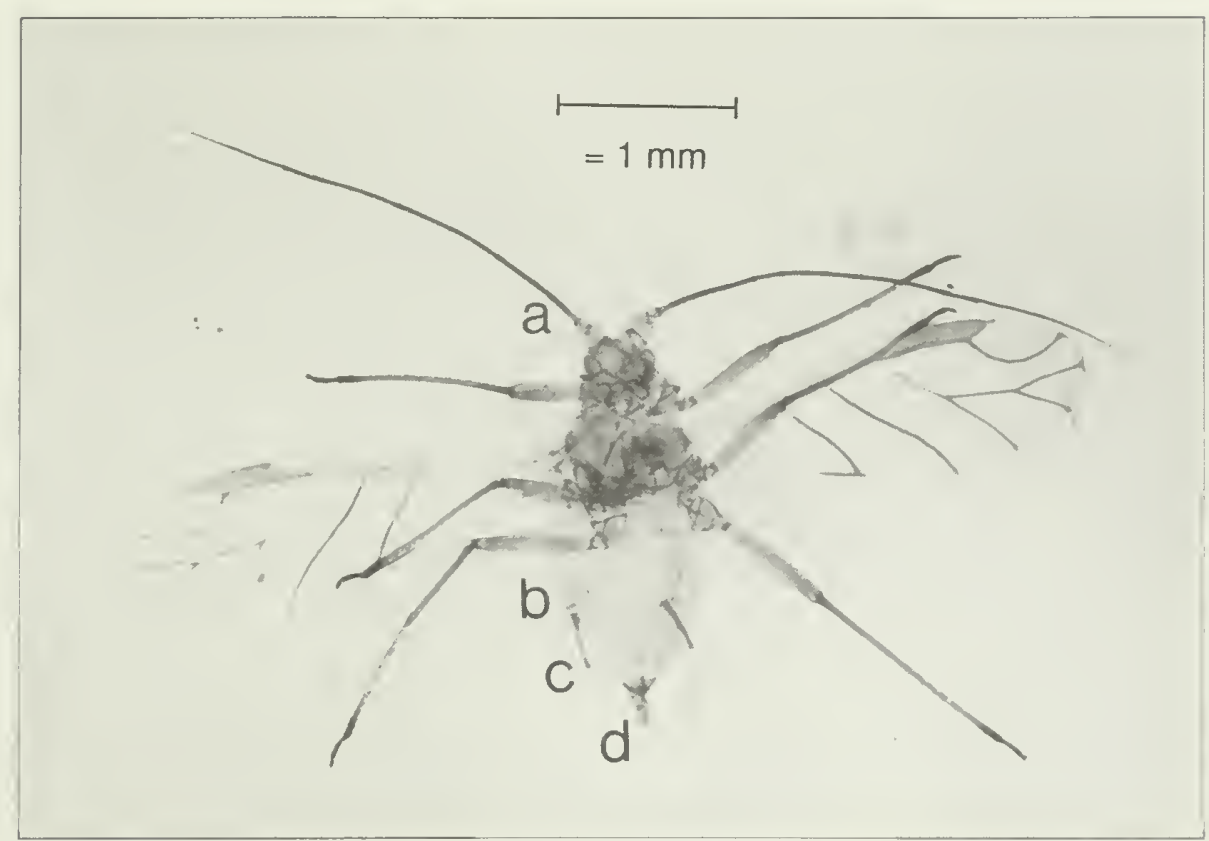

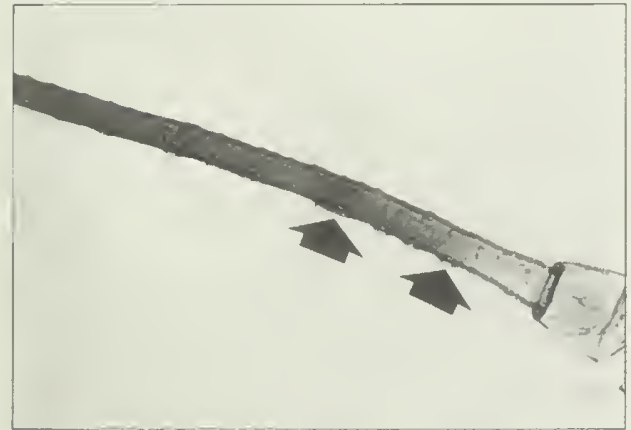

(a) sensoria

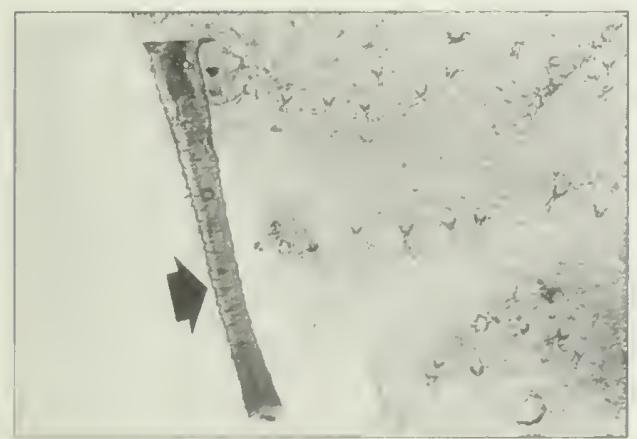

(c) siphunculus

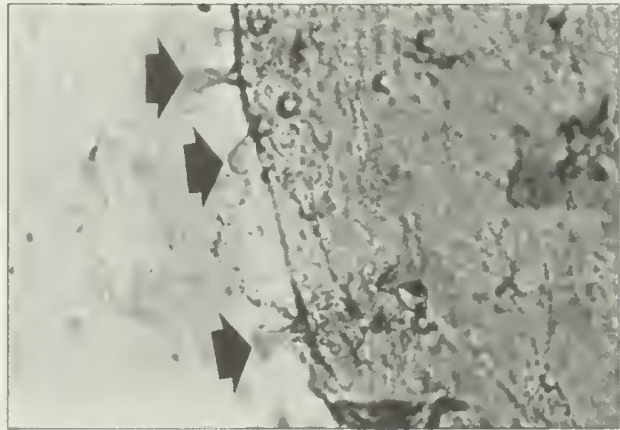

(b) capitate setae

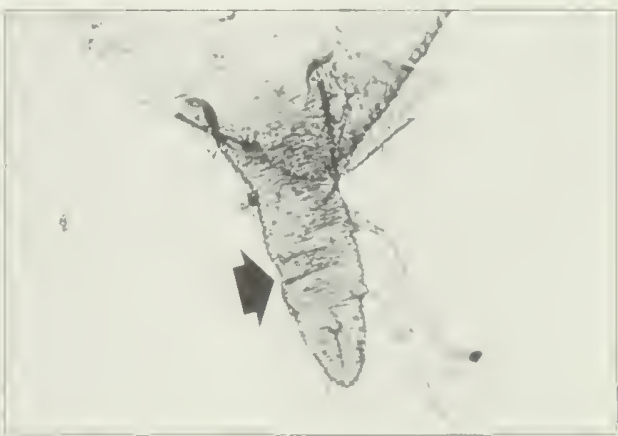

(d) caluda

Aphid mainly pale, bearing numerous short, capitate or funnel-shaped setae and having slender, clongate appendages; antennal segment III with circular sensoria: antennal segments IV and V sometimes having sensoria; abdomen without dorsal patch but usually with segmental dashes and spots and with lateral sclerites: siphunculus short to elongate, not reticulated, and with flange: cauda short. triangular; anal plate entire. References: Blackman and Eastop 1984. Foottit and Richards 1993, Medler and Ghosh 1969. 


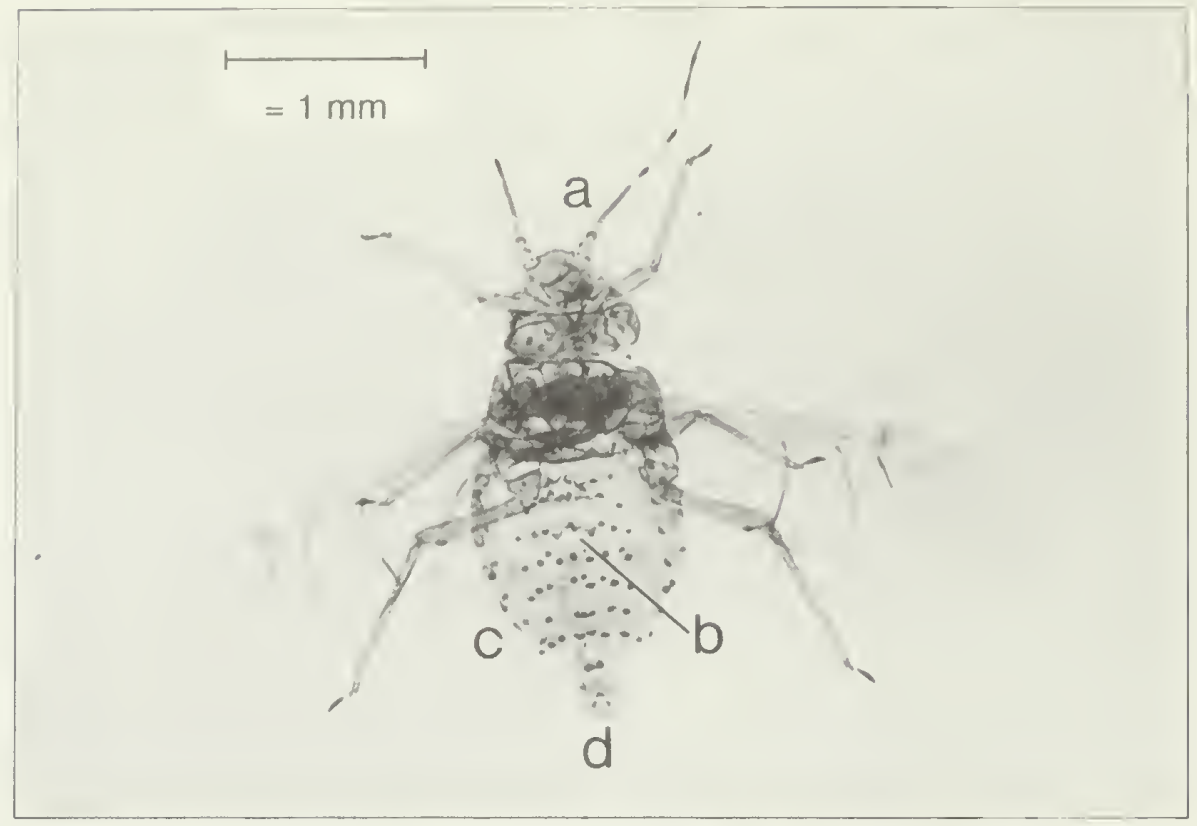

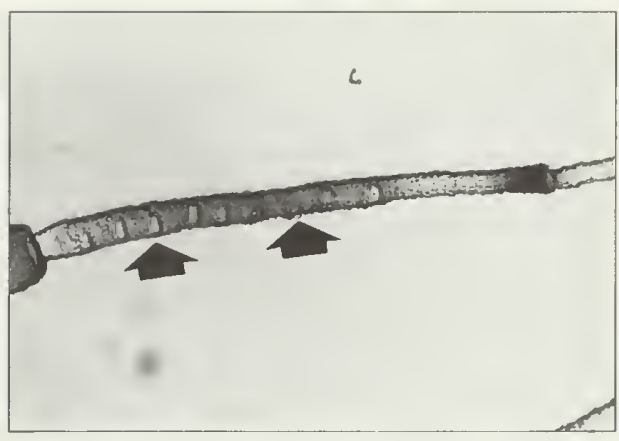

(a) sensoria

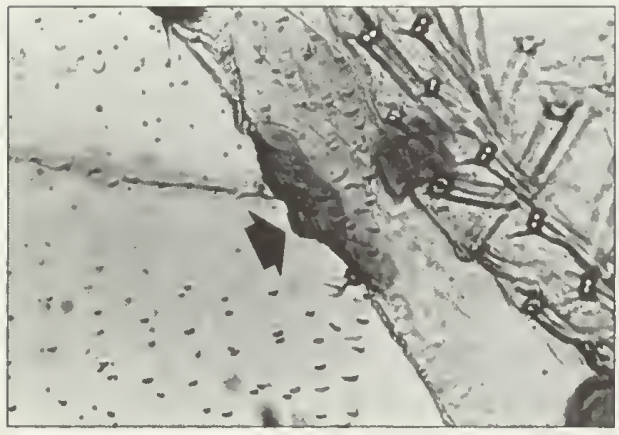

(c) siphunculus

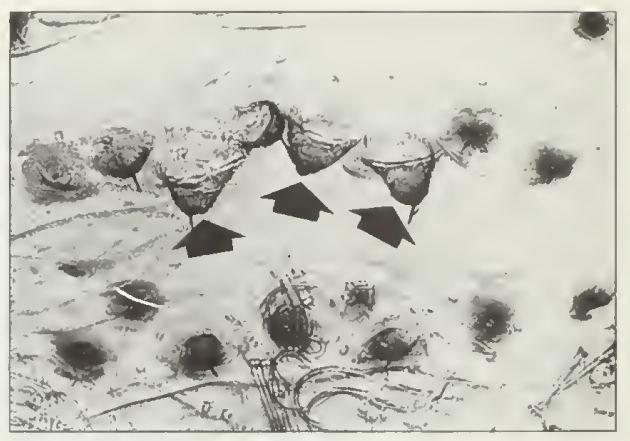

(b) abdominal papillae with setae

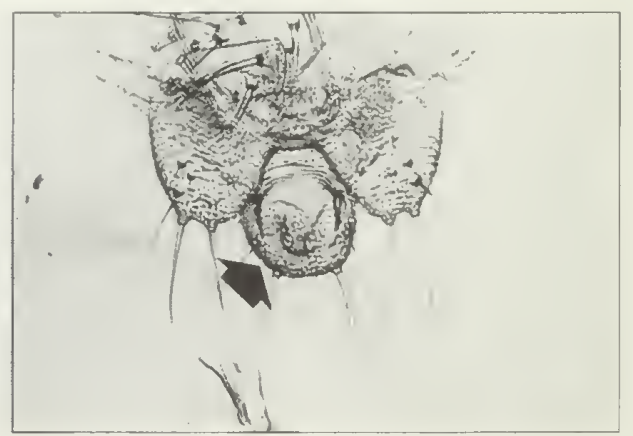

(d) cauda

Antennal segment III with oval sensoria; antennal segments III-VI with dark apices; antennal tubercles poorly developed; head, thorax and abdomen with distinct papillae; abdominal papillae with short, pointed, or blunt setae; siphunculus present as an elevated pore; cauda knobbed; anal plate deeply indented. Reference: Richards 1965. 


\section{Pterocomma bicolor (Oestlund)}

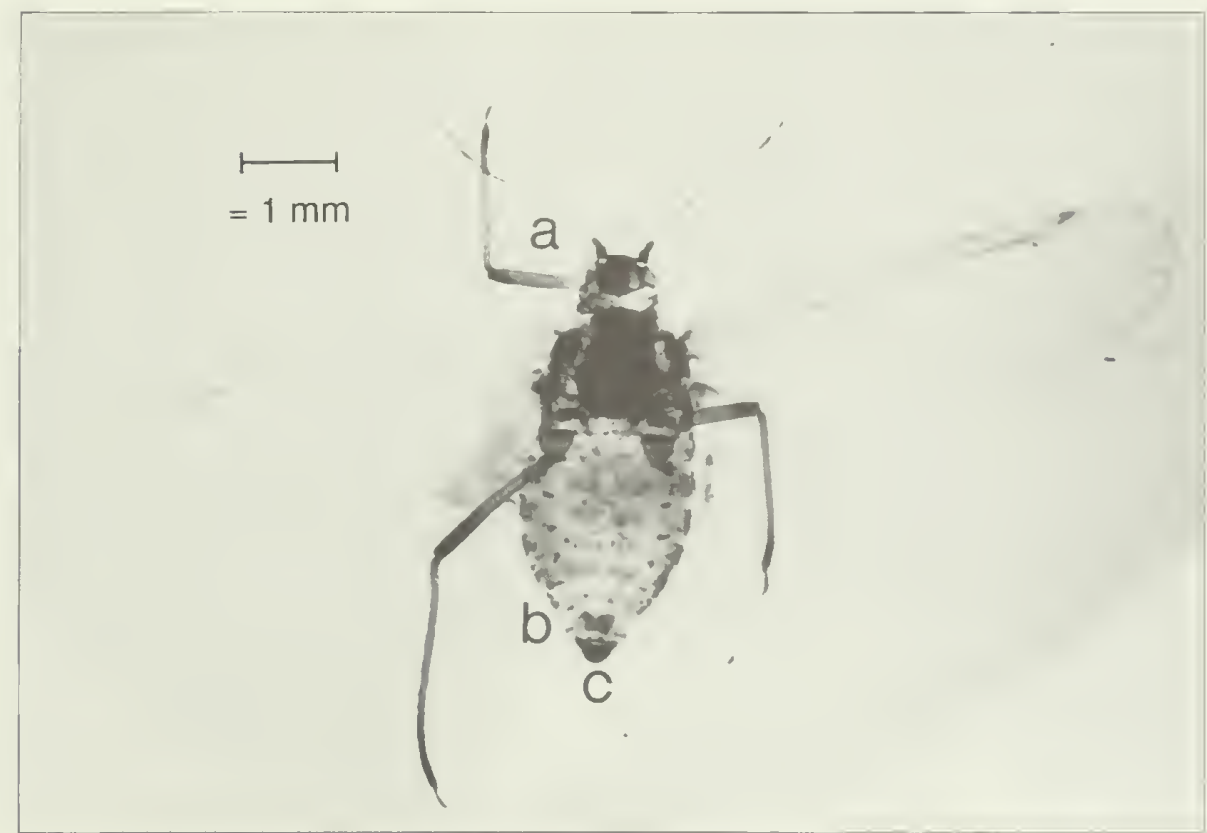

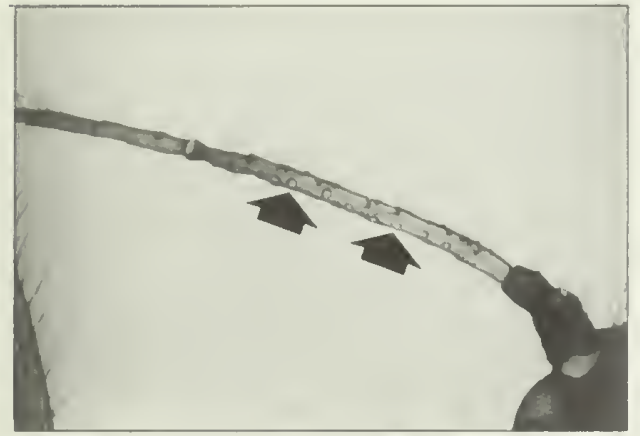

(a) sensoria

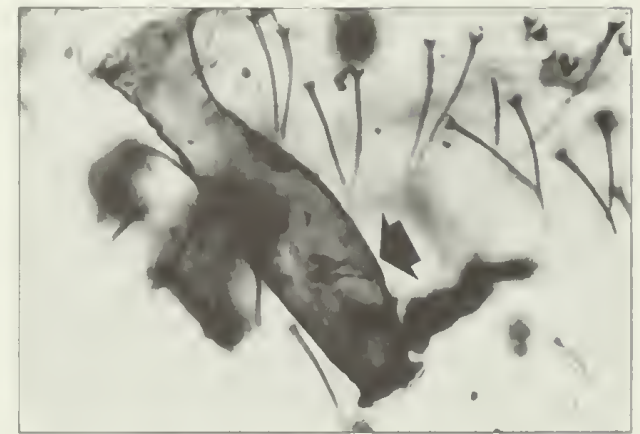

(b) siphunculus

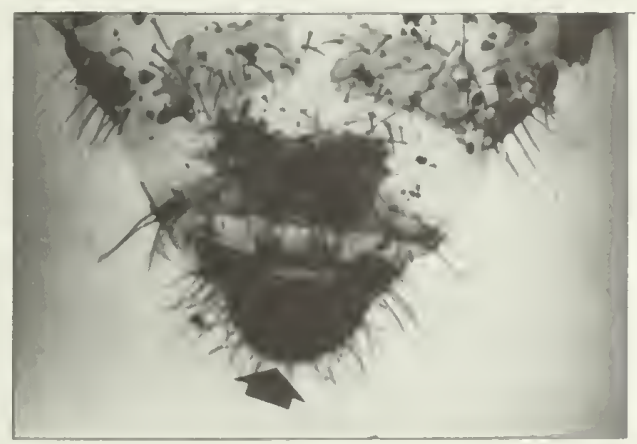

(c) cauda

Antenna light; antennal segments I and VI darker; abdomen with brown dorsal sclerites that vary from rectangular patches on each segment to small spots of various sizes and with lateral sclerites; siphunculus with well-developed apical flange and without imbrications; cauda and anal plate rounded: legs pale: tibia and tarsus with more deeply pigmented apices; wing veins and costal margin pigmented. Reference: Richards 1967. 


\section{Rhodobium porosum (Sanderson)}

yellow rose aphid
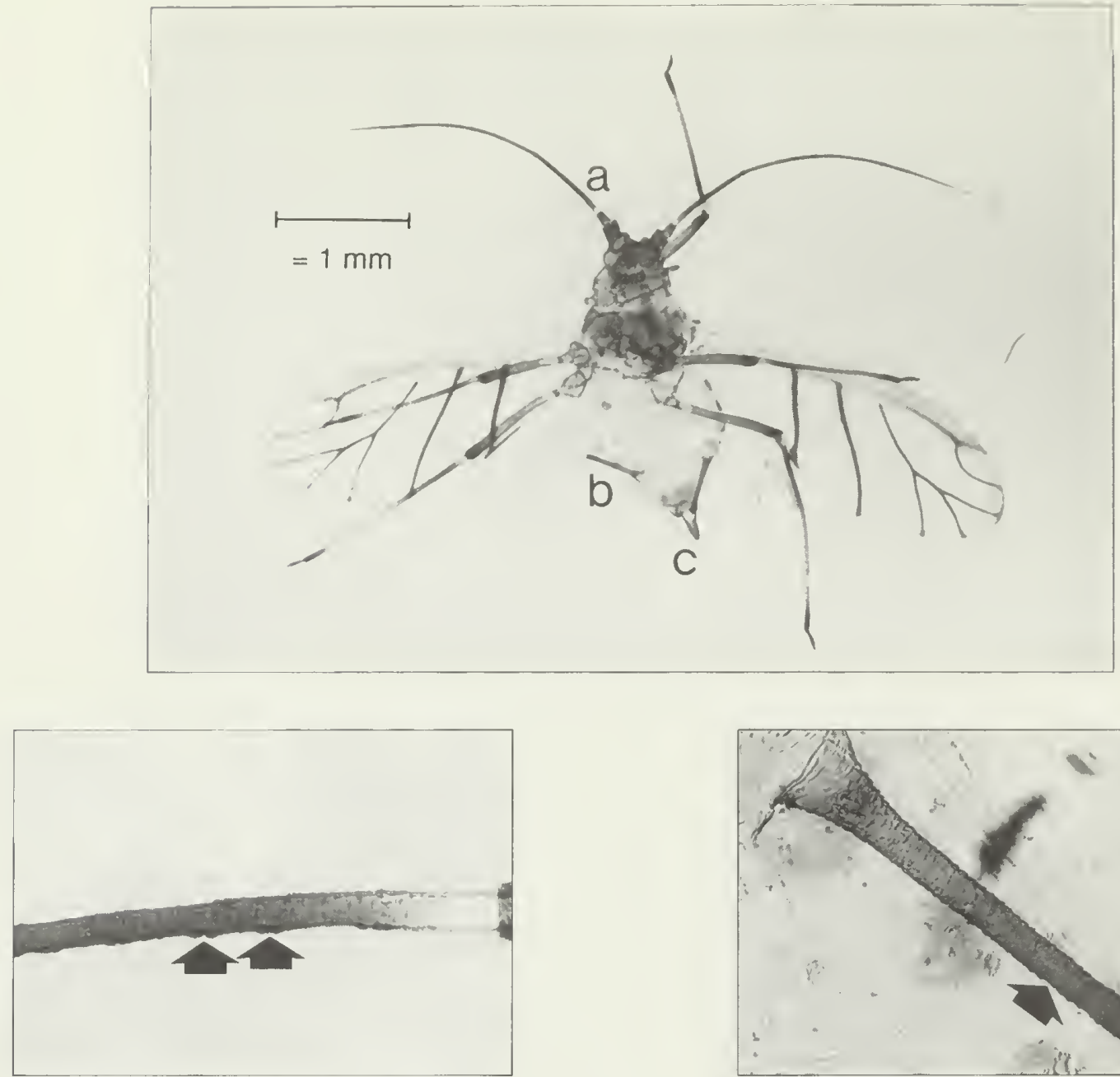

(a) sensoria

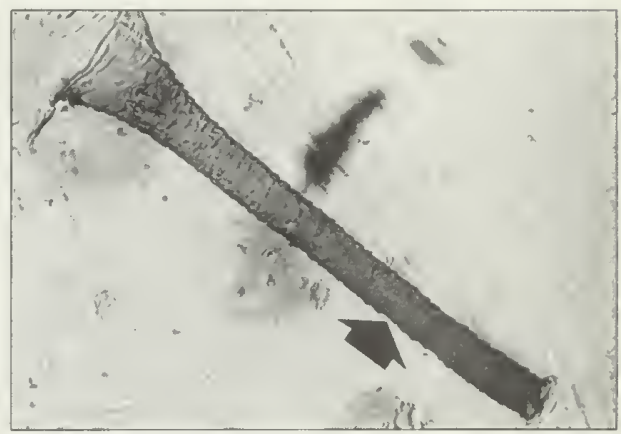

(b) siphunculus

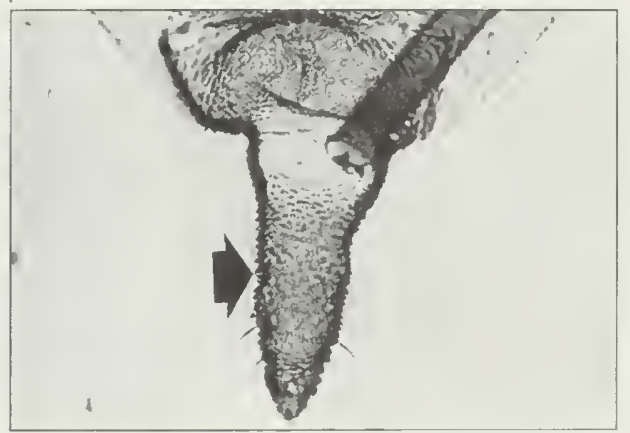

(c) cauda

Antenna dark; antennal segment III proximally pale; abdomen sometimes with light patch or sometimes only with flecks and marginal spots; siphunculus cylindrical, pale, with darker apex; cauda pale, elongate, triangular; legs dark at joints; fore wing with dark second cubital vein. Reference: Taylor et al. 1984. 
Rhopalosiphum insertum (Walker)

apple grain aphid
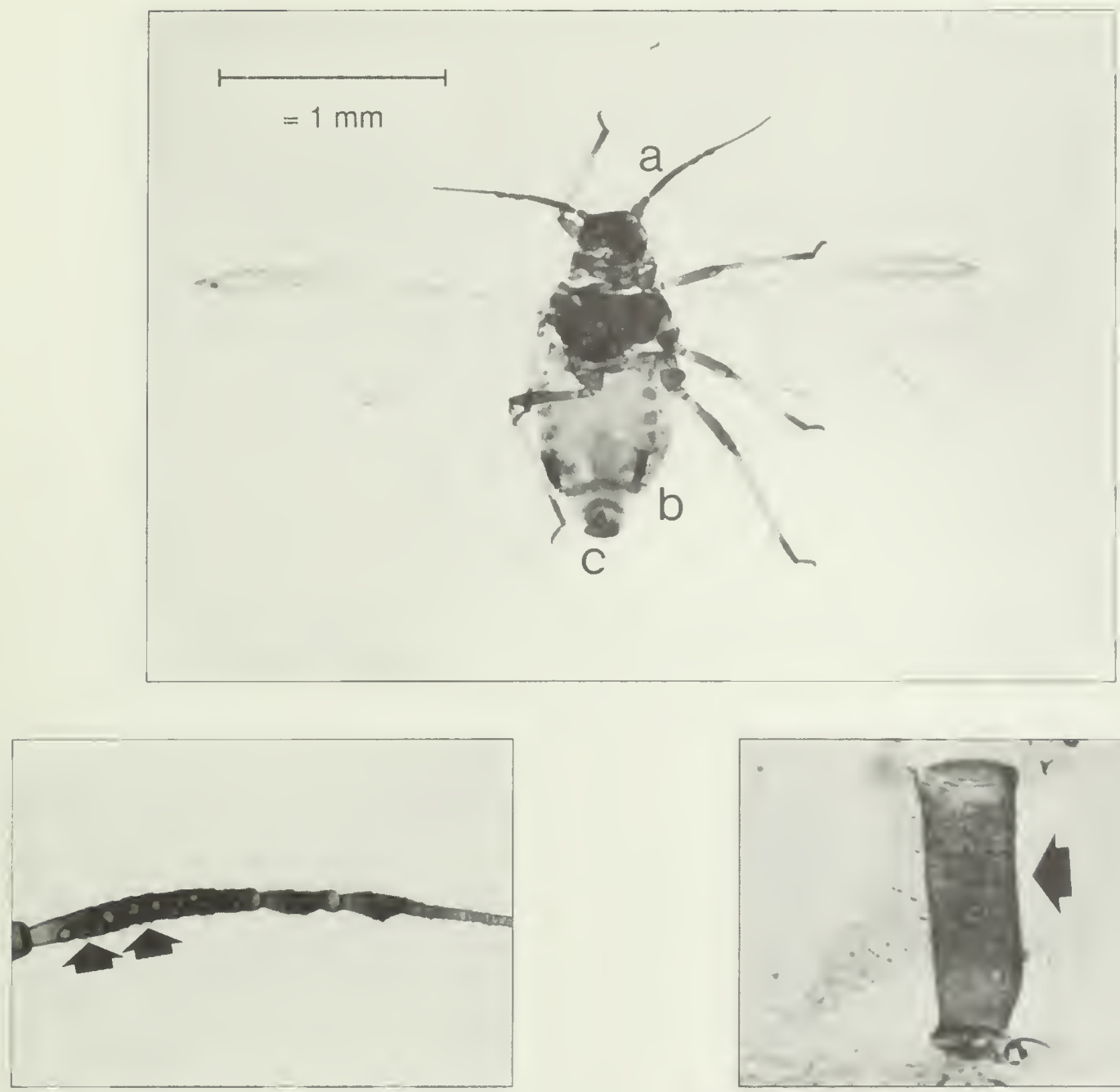

(a) sensoria

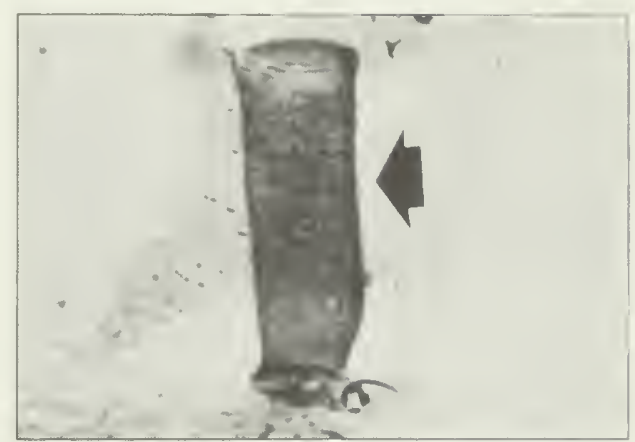

(b) siphlunculus

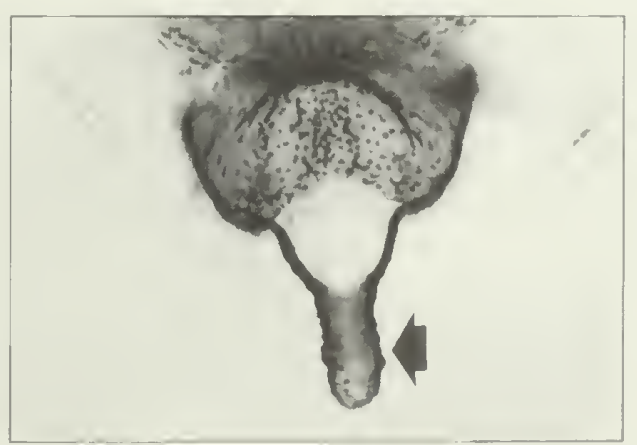

(c) cauda

Antenna 5- or 6-segmented, shorter than body; head and thorax dark: abdomen with brown marginal sclerites and with brown sclerites below the siphunculi; abdominal terga VI-VIII brownish; siphunculus dark, swollen, and constricted near flange; cauda elongate, slightly constricted at middle. References: Heic 1986. Richards 1960. 
Rhopalosiphum maidis (Fitch)

corn leaf aphid

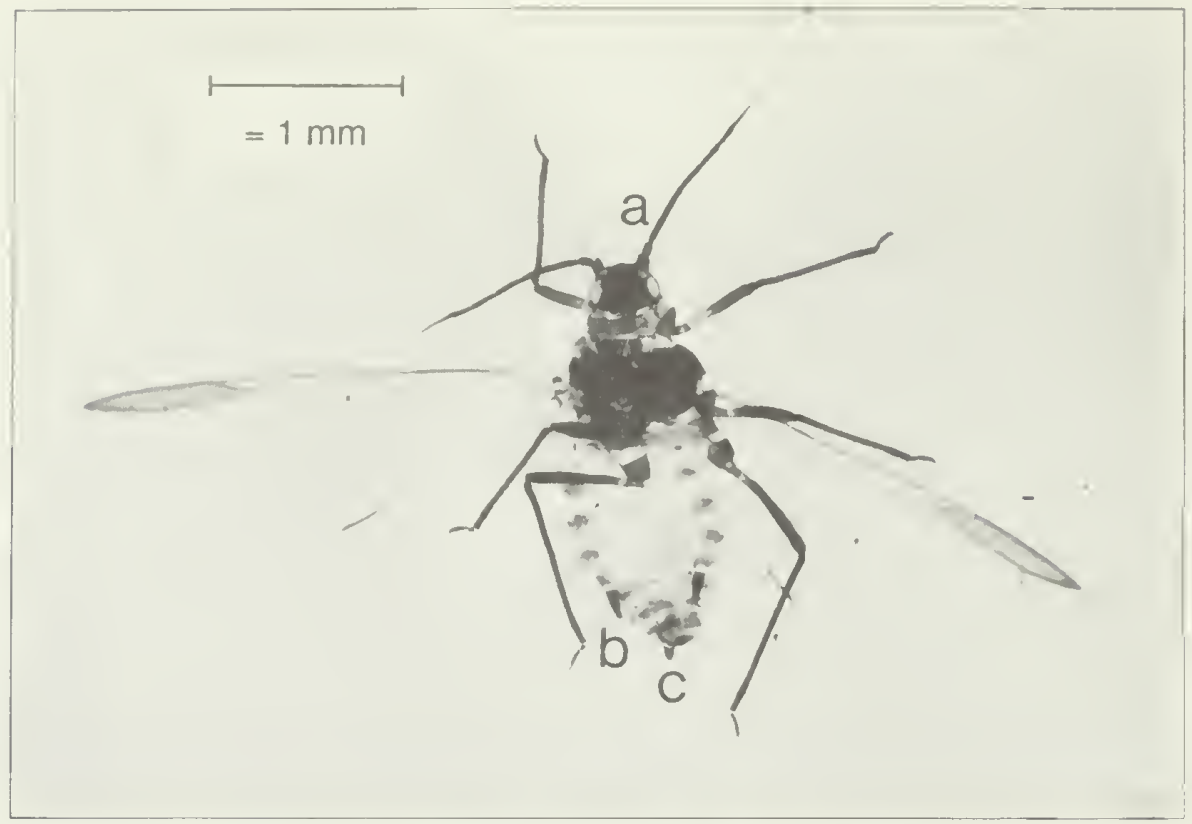

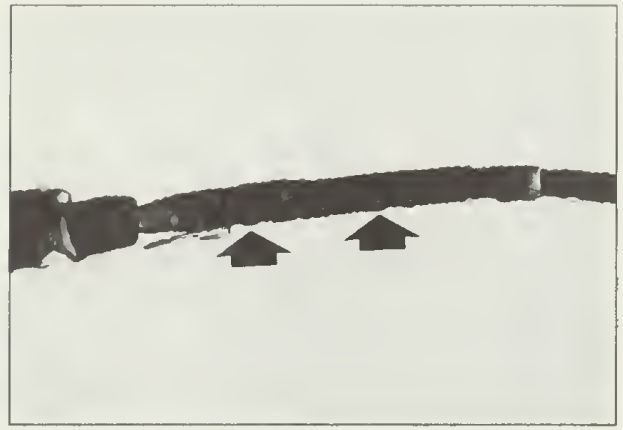

(a) sensoria

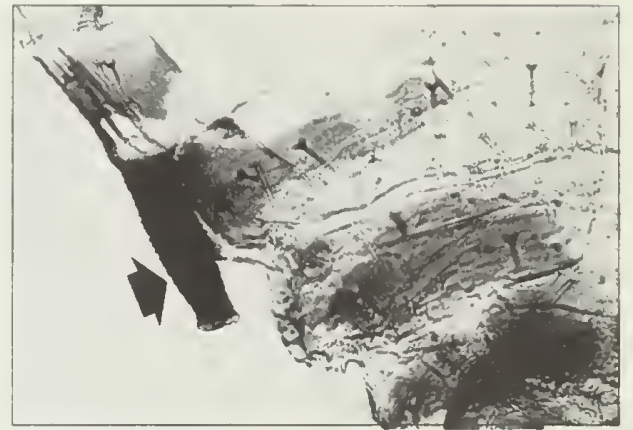

(b) siphunculus

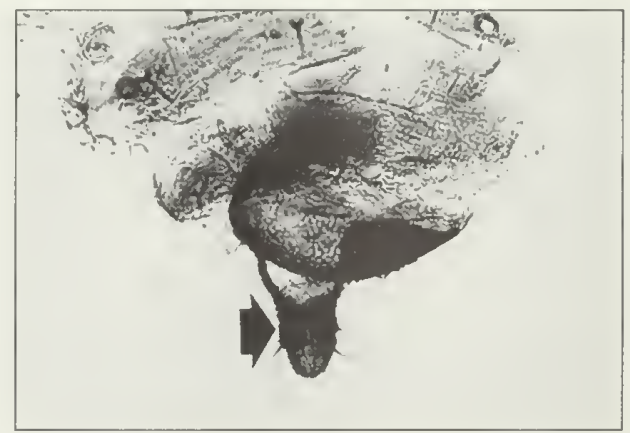

(c) cauda

Prothorax with well-developed lateral tubercles; abdomen with marginal sclerites; siphunculus very rough, with weakly developed flange, and with sclerites in front and behind; cauda elongate, normally constricted at middle, and with 2 or 3 slender, curved, pointed setae on each side. References: Heie 1986, Richards 1960. 


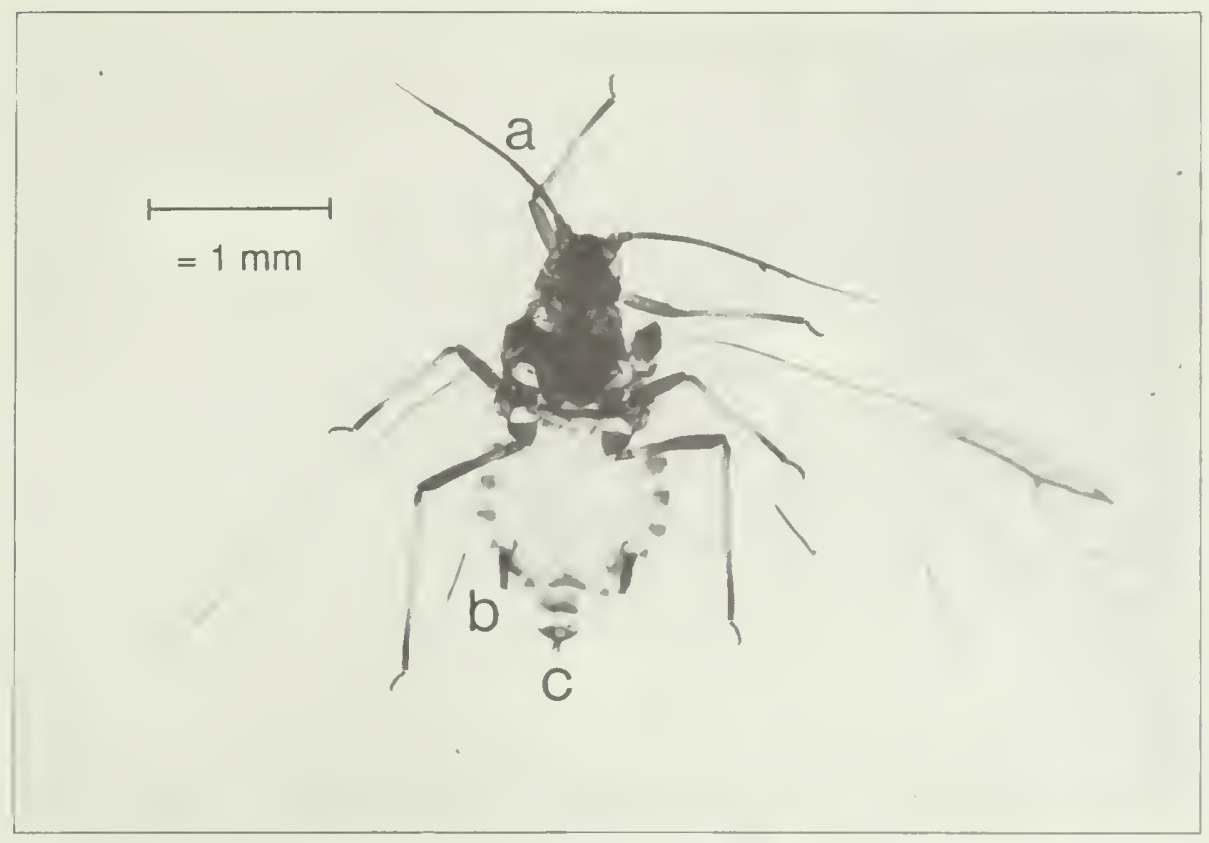

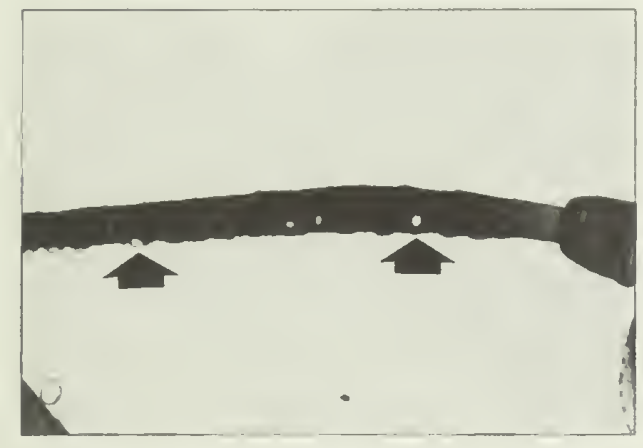

(a) sensoria

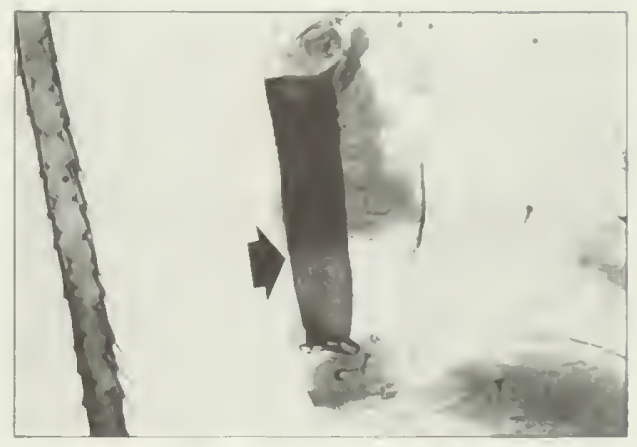

(b) siphunculus

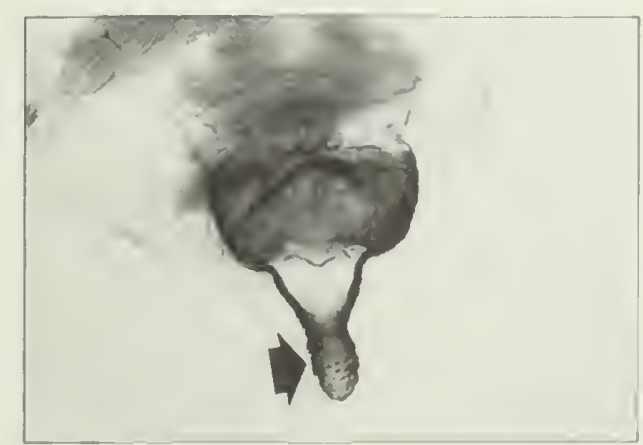

(c) cauda

Antenna 6-segmented; head and thorax dark: abdomen with brown marginal sclerites and with large sclerites behind the siphunculi; siphunculus dark, longer than cauda, and often slightly swollen and distinctly constricted below welldeveloped flange. Reference: Heie 1986. 


\section{Rhopalosiphum rufiabdominale (Sasaki)}

rice root aphid

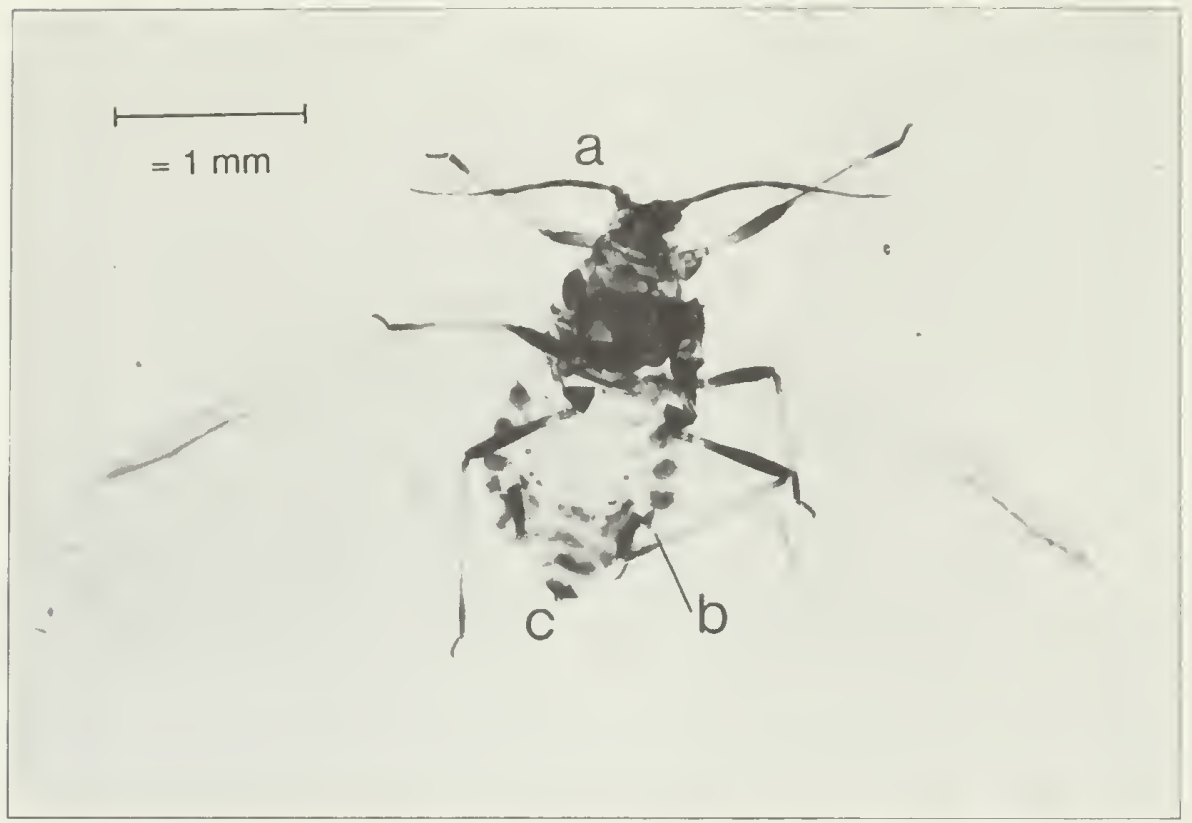

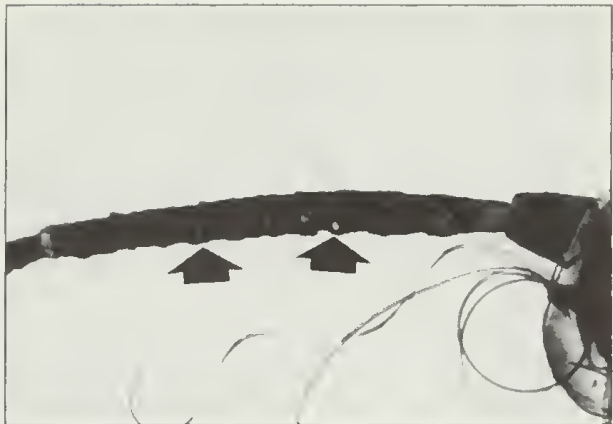

(a) sensoria

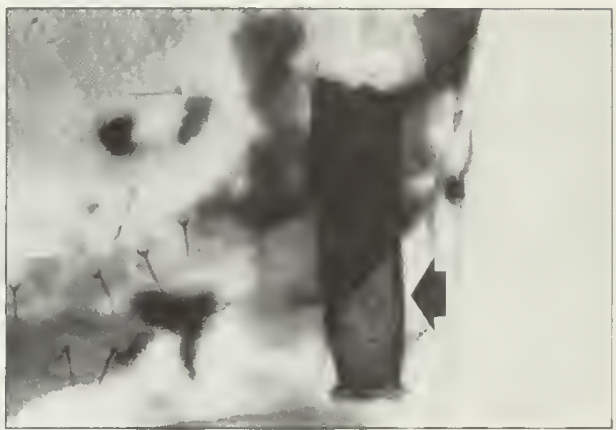

(b) siphunculus

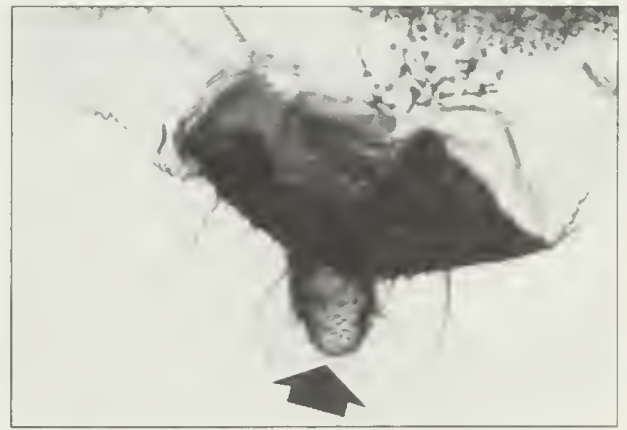

(c) cauda

Antenna usually 5-segmented and with long setae; antennal segment III with 16-22 sensoria; abdominal tergum VIII with 4 or 5 setae; siphunculus nearly cylindrical or swollen, with spots at base. References: Heie 1986, Richards 1960. 
Schizaphis graminum (Rondani)

greenbug

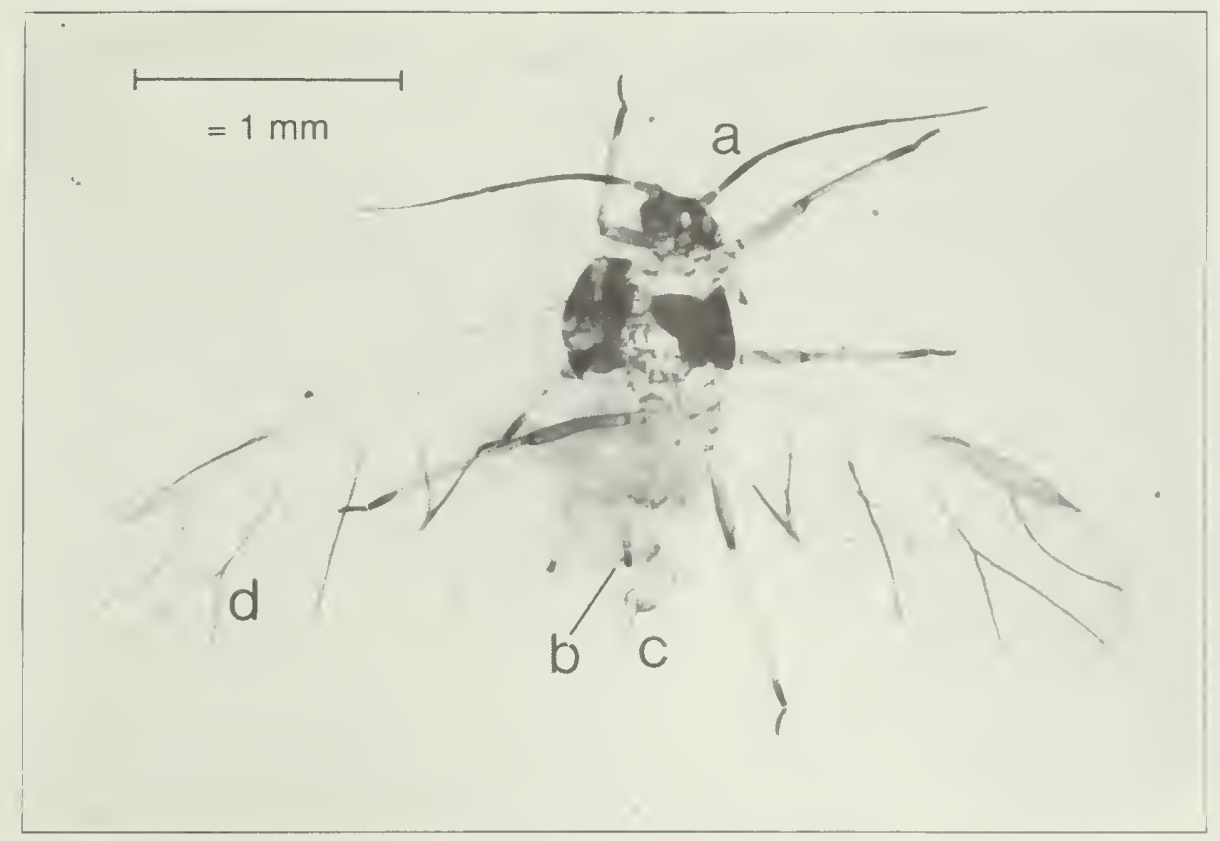

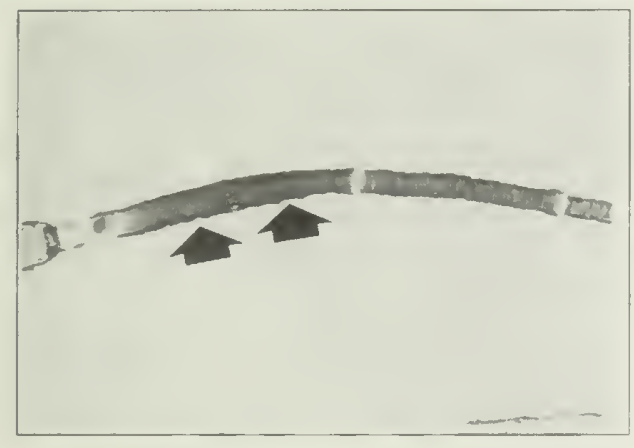

(a) sensoria

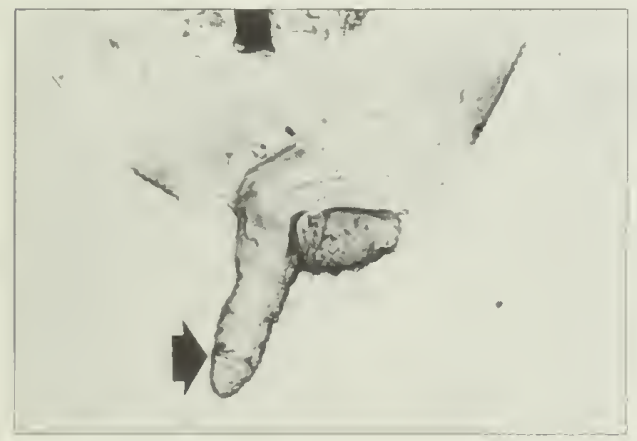

(c) cauda

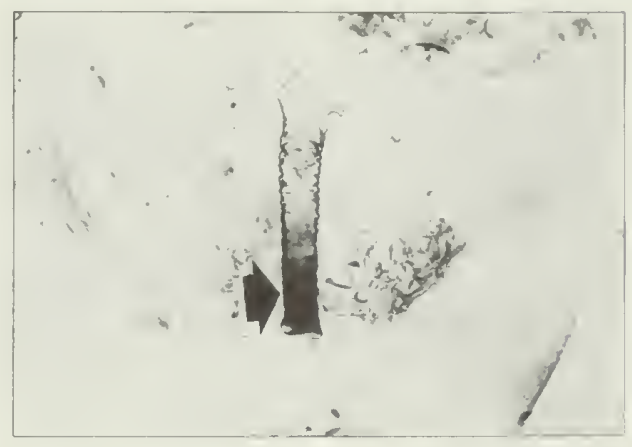

(b) siplunculus

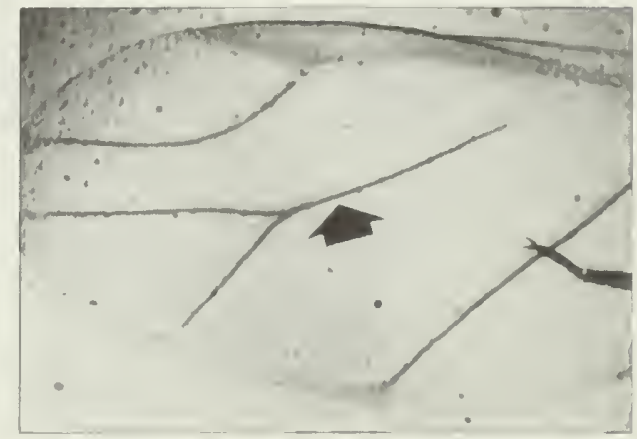

(d) l-forked media of fore wing

Antenna shorter than body; antennal segment III with 6-9 sensoria: processus terminalis at least three times as long as base of antennal segment VI: siphunculus pale, short, cylindrical, with dark apex, with transverse wrinkles, and without well-developed flange; cauda elongate; fore wing with 1-forked media. References: Blackman and Eastop 1984. Kono and Papp 1977. Medler and Ghosh 1969. 


\section{Sipha (Rungsia) elegans del Guercio}

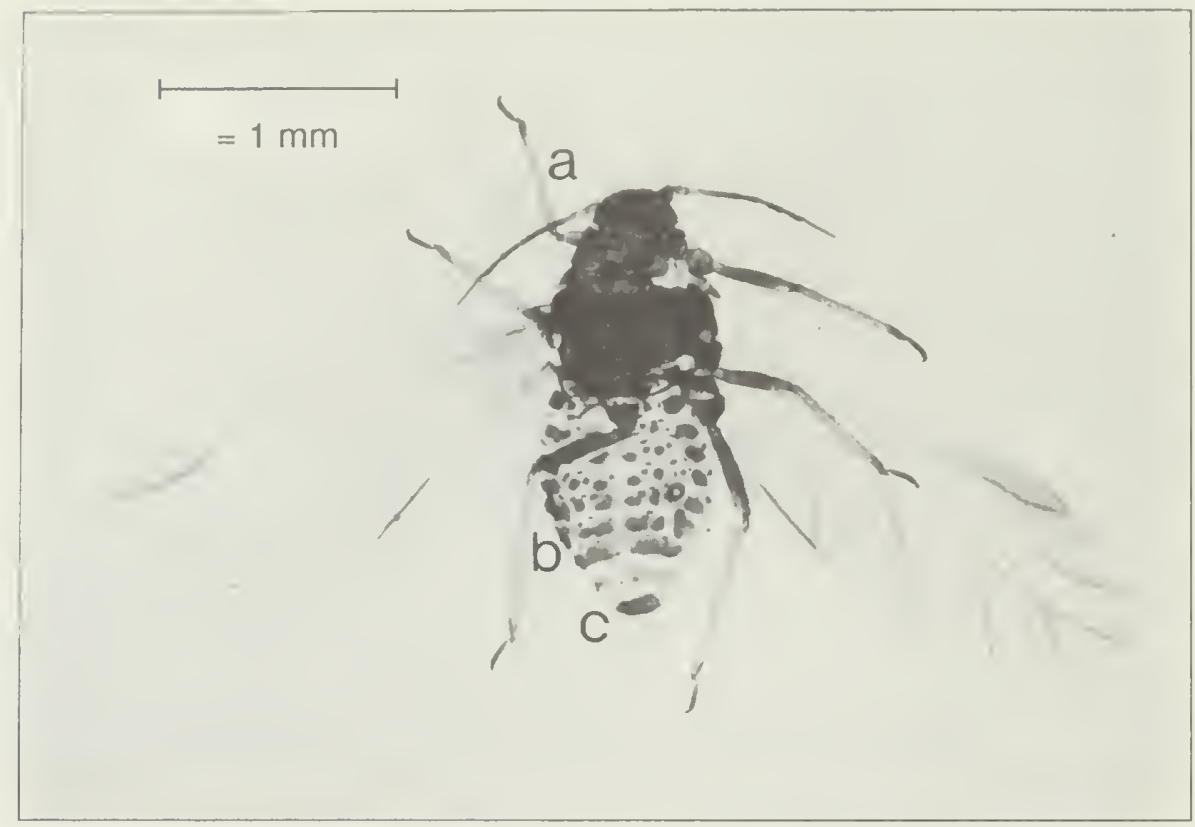

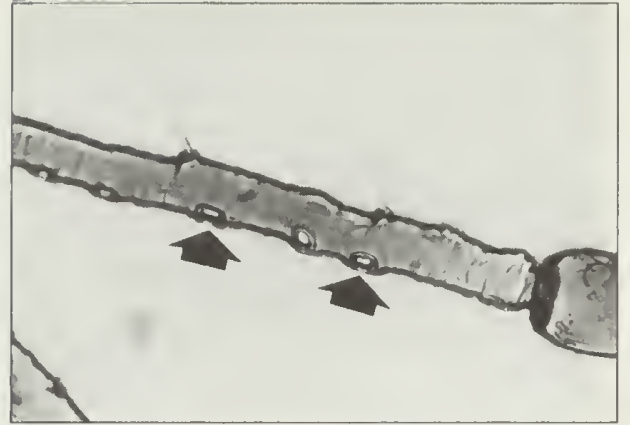

(a) sensoria

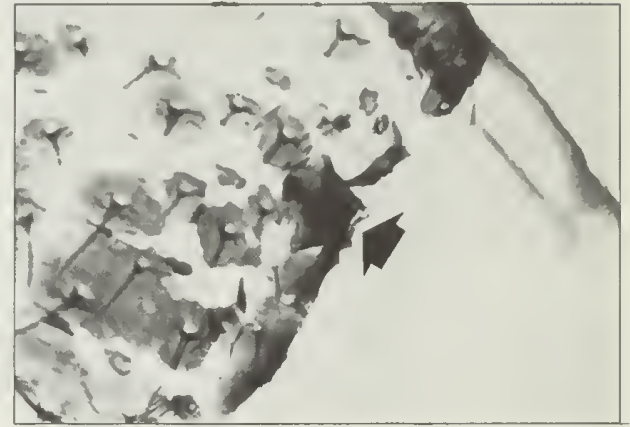

(b) siphunculus

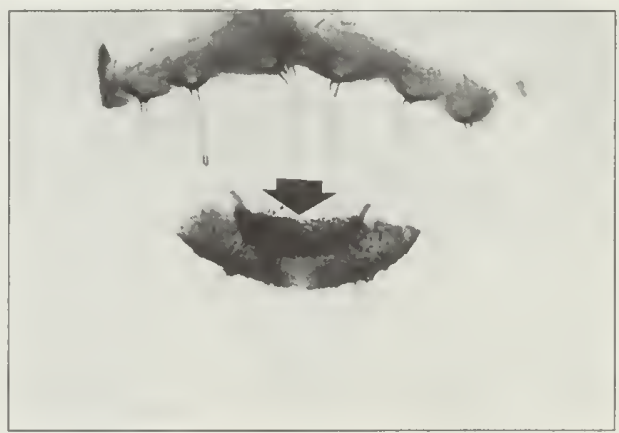

(c) cauda

Antenna 5-segmented; antennal segment III with 4-10 sensoria; processus terminalis less than 2.5 times the length of the base of antennal segment $\mathrm{V}$; antennal tubercles undeveloped; abdomen smooth, with dark spots and short cross bars, the pigmentation not touching siphuncular base; siphunculus truncate, not reticulated, and shorter than antennal segment I; cauda rounded, arc-shaped; anal plate entire. References: Blackman and Eastop 1984, Heie 1982, Richards 1972. 


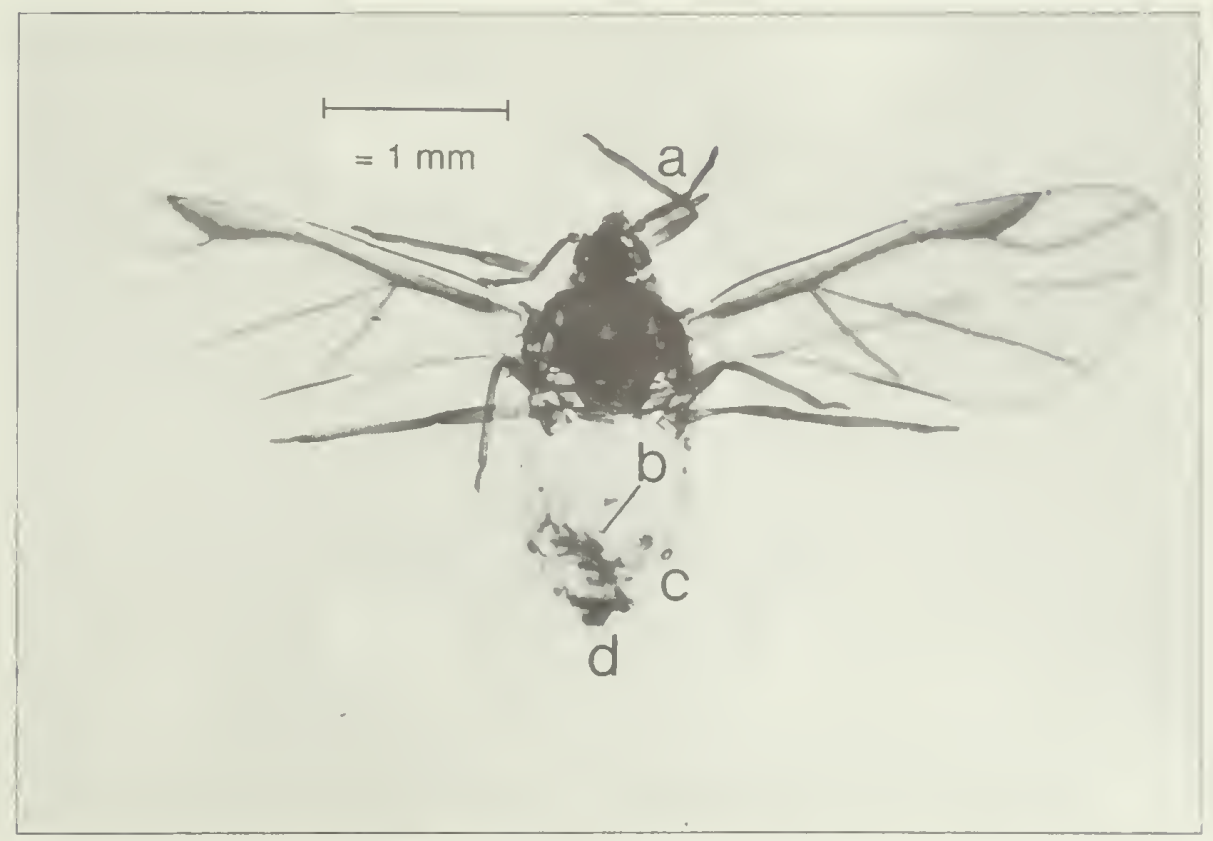

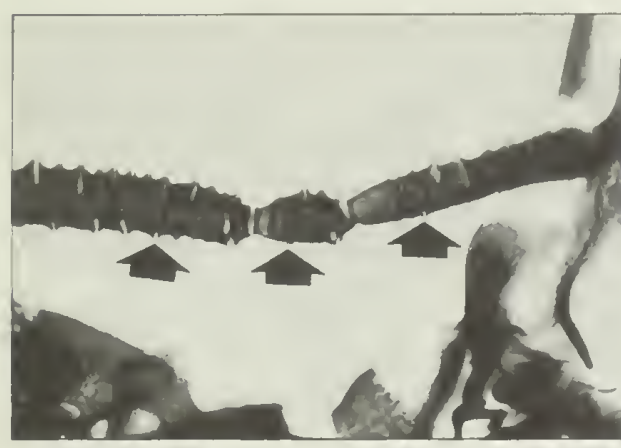

(a) sensoria

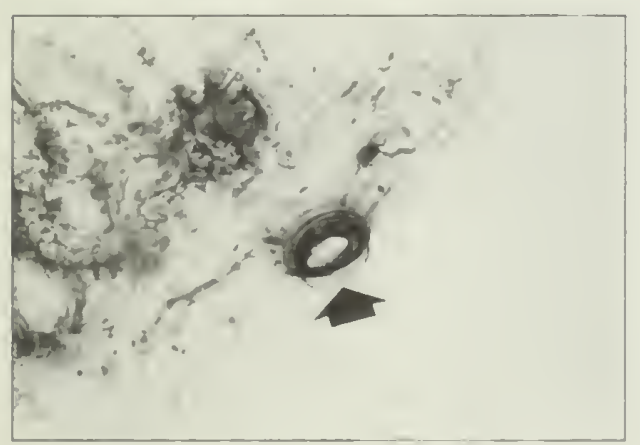

(c) siphunculus

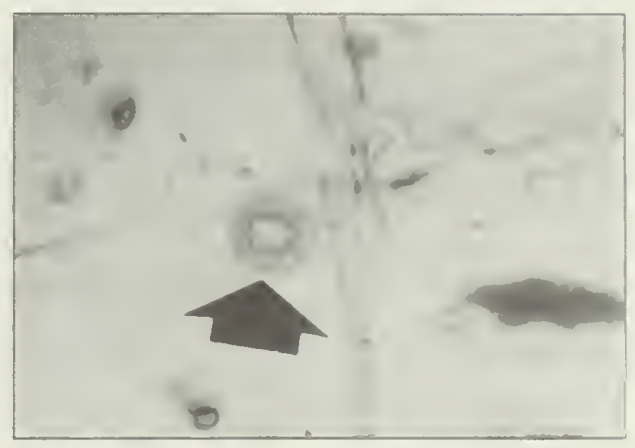

(b) wax plates

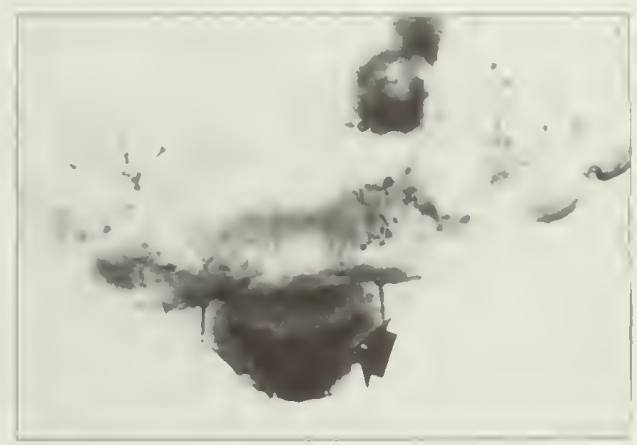

(d) cauda

Antennal segments III-V with numerous ring-like sensoria: antennal segments III and $\mathrm{V}$ much longer than segment IV: abdomen with wax plates: siphunculus short, conical, with narrow flange; cauda rounded; anal plate entire; fore wing with usually unbranched and rarely 1 -forked media. References: Foottit and Richards 1993, Martin 1983, Palmer 1952. 


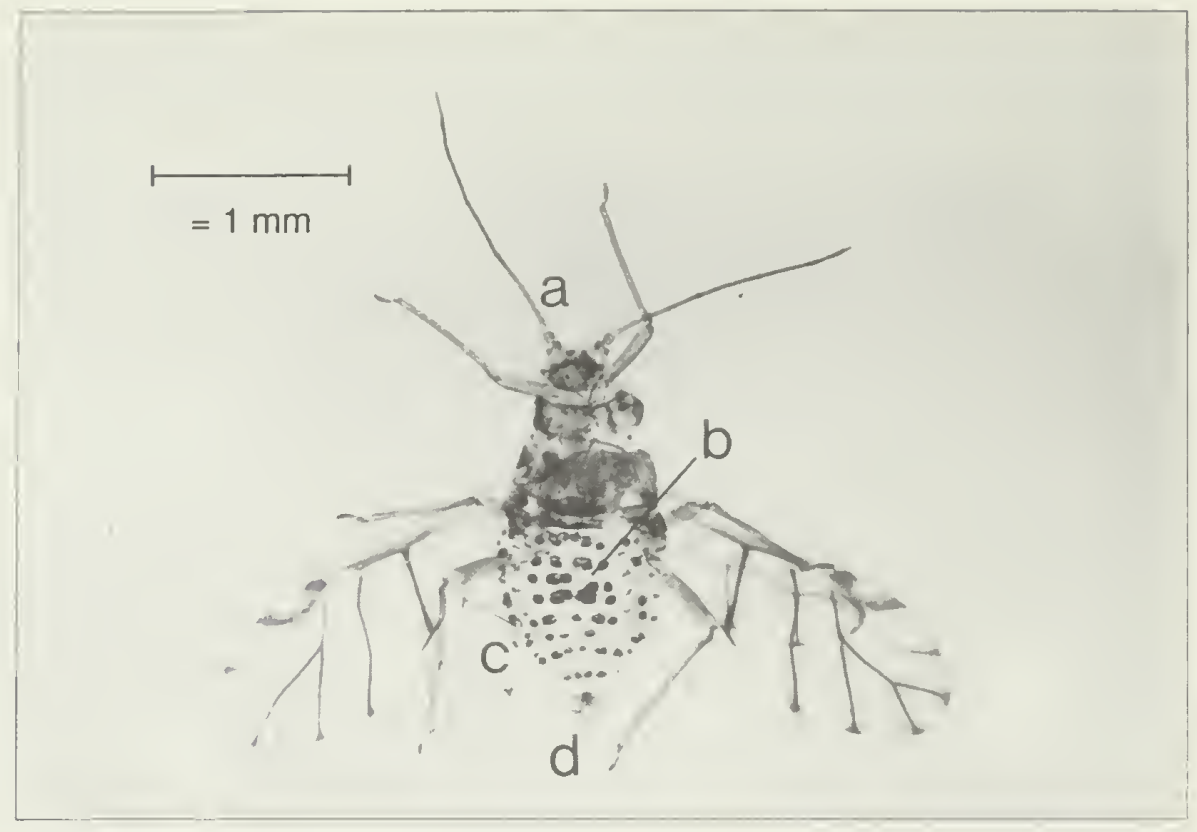

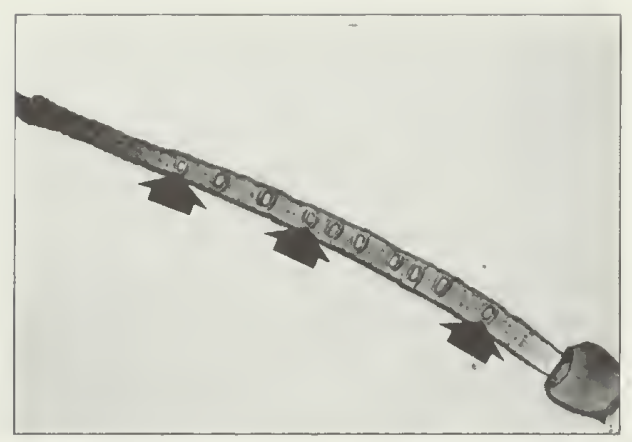

(a) sensoria

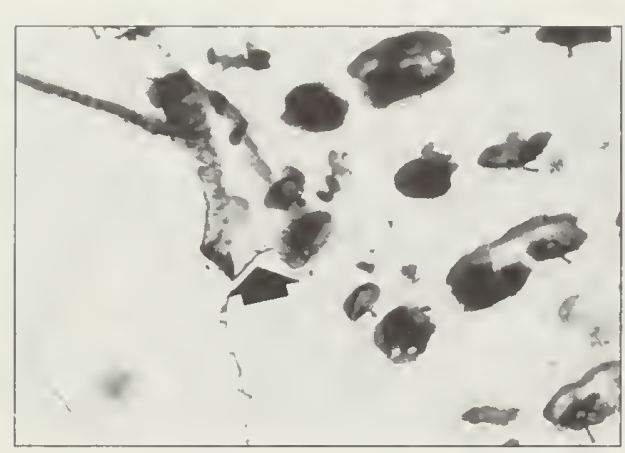

(c) siphunculus

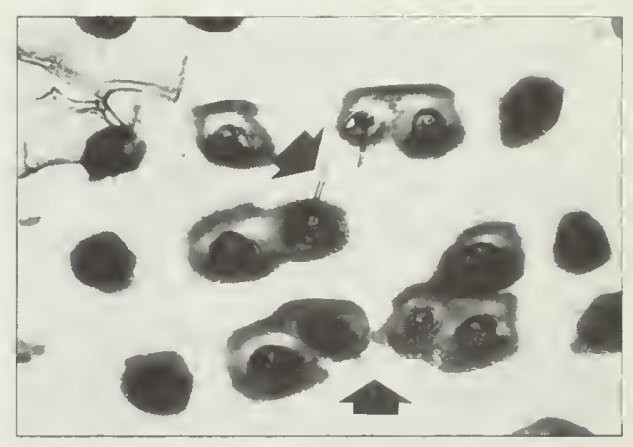

(b) capitate setae on abdomen

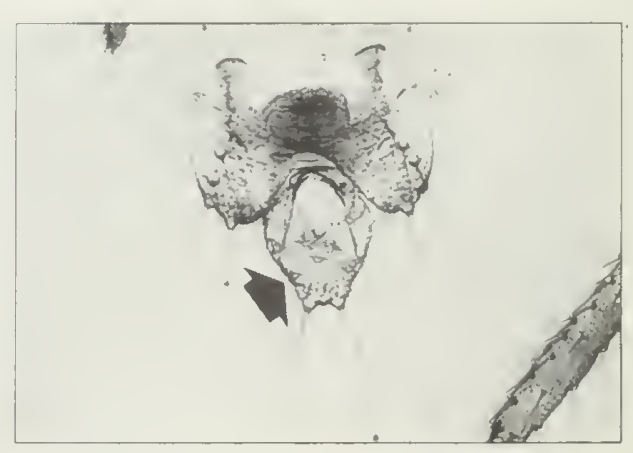

(d) cauda

Aphid yellowish when alive; antennal segment III with circular to oval sensoria that are proximally placed in 1 row; antennal tubercles poorly developed; abdomen with small, dark dorsal spots around bases of short capitate setae; siphunculus truncate, without flange; cauda knobbed; anal plate bilobed; wing veins dark-bordered, ending in small, dark spots. References: Foottit and Richards 1993, Heie 1982, Richards 1965. 


\section{Trama rara Mordvilko}

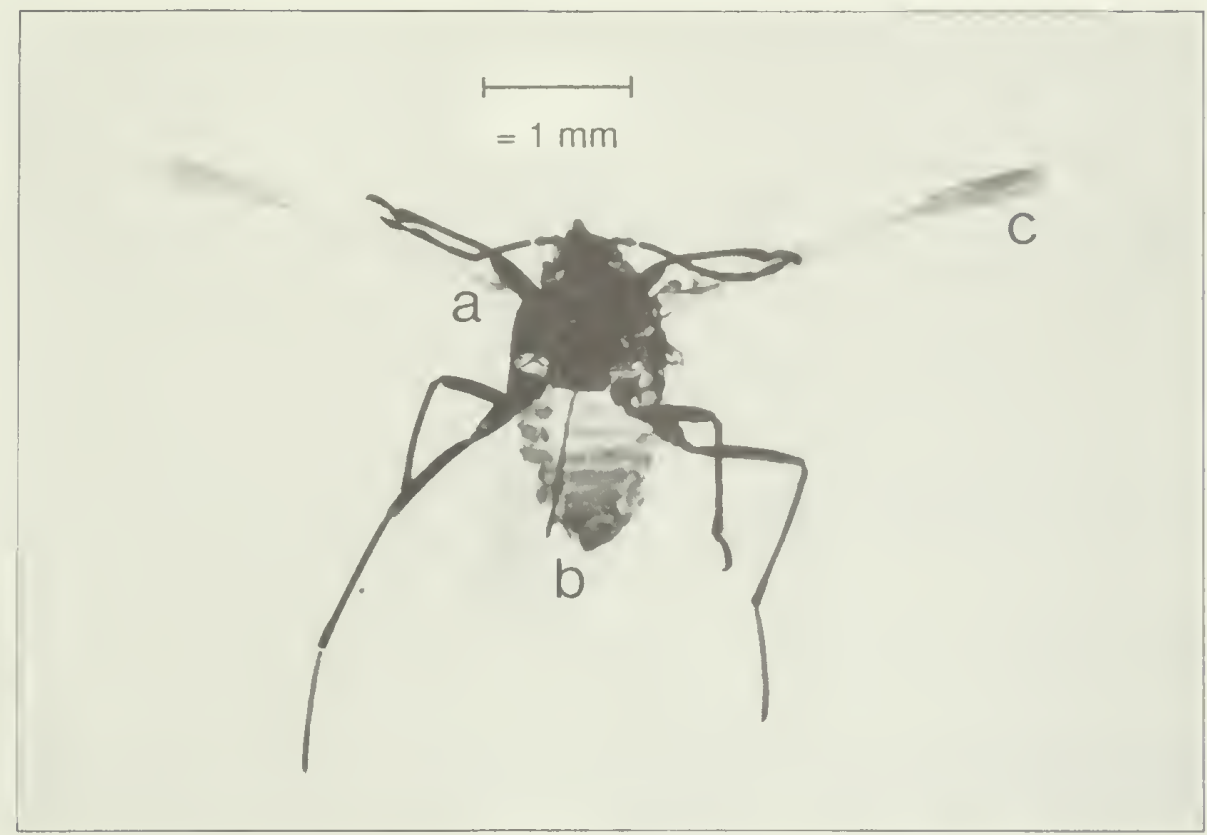

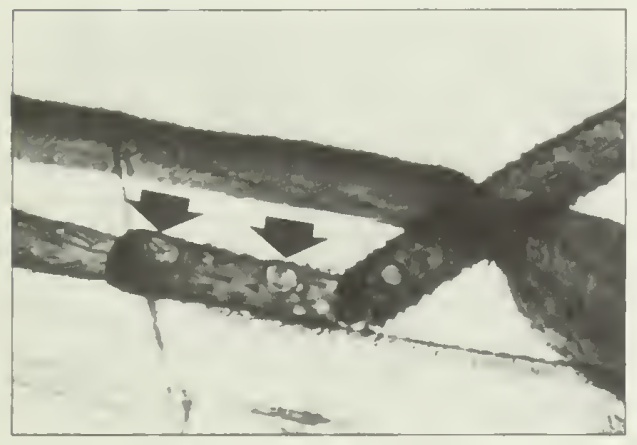

(a) sensoria

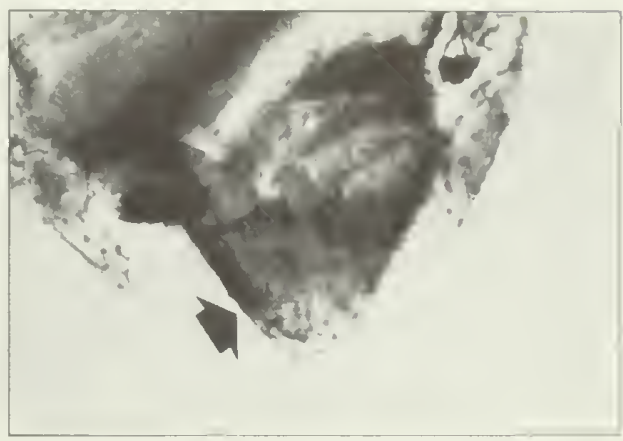

(b) cauda

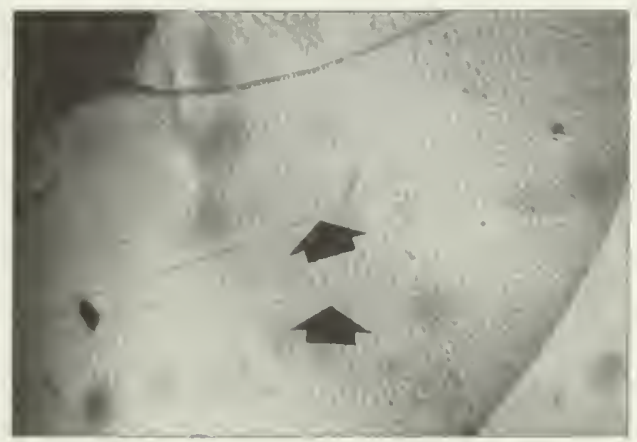

(c) I-forked media of fore wing

Antenna dark: abdomen with numerous pointed, fine, drooping setae; abdomen also with long stripes covering two-thirds its width; siphunculus absent; cauda semilunar; hind tarsus very long; wing veins pale, especially the 1-forked media. References: Palmer 1952, Taylor et al. 1984. 
Uroleucon (Uromelan) taraxaci (Kaltenbach)

dark dandelion aphid

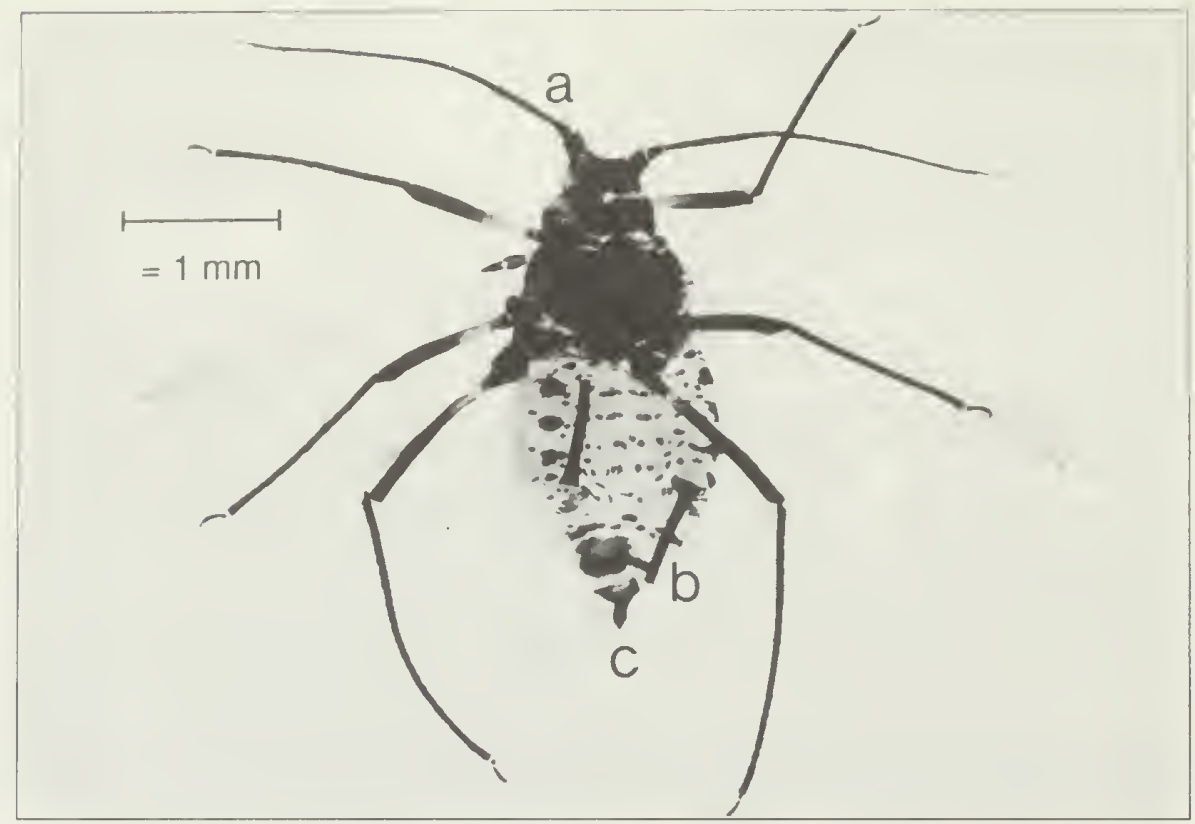

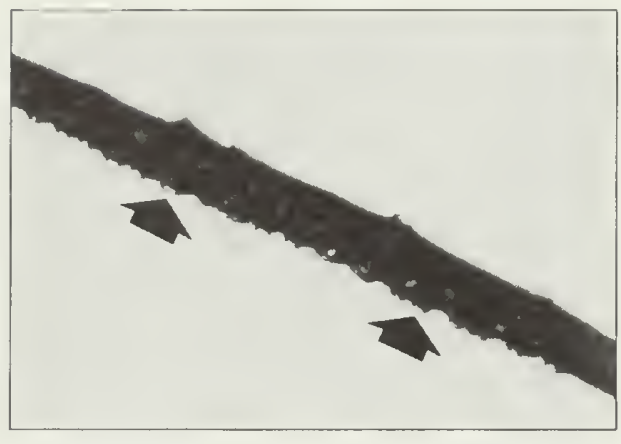

(a) sensoria

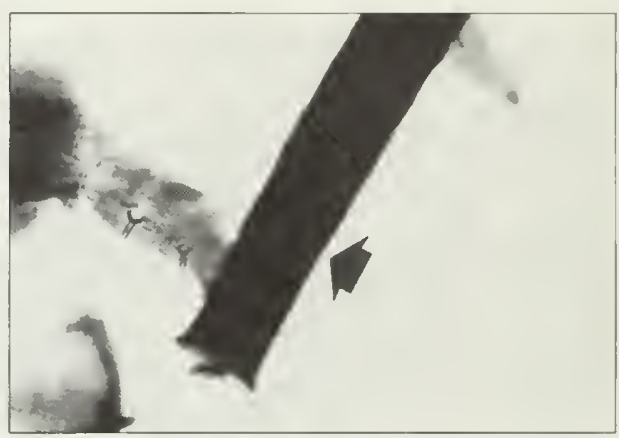

(b) siphunculus

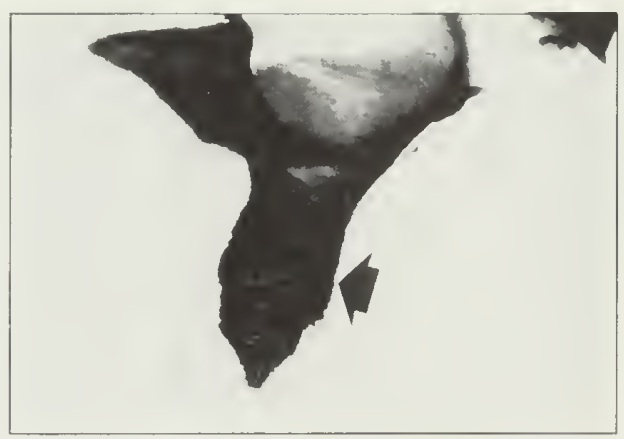

(c) cauda

Live aphid very dark reddish brown; head and thorax black; antennal segment III only with numerous sensoria; abdominal terga with spots at bases of setae; siphunculus long, black, cylindrical, reticulated at apex; cauda black, medium length, tapering; legs black, except for pale base of femur; hind tibia with long setae. Reference: Palmer 1952. 


\section{Glossary}

(Definitions from Foottit and Richards 1993, Miyazaki 1987, Taylor et al. 1984, Torre-Bueno 1985.)

abdomen The third part of the body of an insect; in aphids, made up of 8 segments plus the cauda.

alate Winged form.

anal plate The sclerotized ventral part of the abdominal segment in front of the cauda (see Therioaphis sp., Sipha (Rungsia) elegans).

antenna (pl. antennae) A segmented organ arising from the front of the head.

antennal tubercle Swelling of the head capsule at base of antenna (see Myzus persicae).

anterior Positioned in front.

apex (pl. apices) The point farthest away from the base: the tip.

apical Pertaining to the apex.

basal Pertaining to the base.

base The point closest to the body.

capitate setae Hairs with knobbed apices (see Pleotrichophorus sp.).

cauda The "tail"; the apex of the abdomen; can be many different shapes.

clavate Clubbed (see Cavariella aegopodii).

claw A paired organ at the end of an insect's leg.

costa The thickened top margin of the fore wing.

costal Pertaining to the costa (see Pterocomma bicolor).

coxa (pl. coxae) The basal leg segment, where the leg is attached to the body.

cubitus The basal vein of the wing that branches within the common longitudinal vein, therefore appearing as 2 separate veins (see Rhodohium porosum).

denticulate Set with small teeth or notches (see Nearcaluphis hakeri). 
distal The region farthest from the body (see Lipaphis erysimi).

dorsal Located on the upper surface.

dorsal patch An area of pigmentation that is joined over more than 1 abdominal tergum (see Myzus persicae, Cryptomyzus galeopsidis).

femur (pl. femora) Usually the stoutest leg segment; it bears the tibia at its distal end.

flange A projecting rim or edge (see Nearctaphis crataegifoliae, Brevicoryne brassicae, Pterocomma bicolor).

imbrication An arrangement resembling fish scales or roof shingles (see Brachycaudus helichrysi).

infuscated Smoky gray-brown, with a blackish tinge (see Myzocallis (Neomyzocallis) punctata).

margin The narrow part of a surface, near the edge.

marginal Near the margin.

media A vein that runs off the common longitudinal vein, towards the hind margin of the wing; it can be unbranched, 1-forked or 2-forked (see Forda formicaria, Schizaphis graminum).

melanistic Dark or blackish (see Myzocallis (Neomyzocallis) punctata).

oblique Slanted.

papilla (pl. papillae) A projection of the body wall (see Drepanaphis acerifoliae, Drepanaphis simpsoni).

processus terminalis A slender projection at the end of the last antennal segment (see Ovatus crataegarius, Cinara sp., Capitophorus hippophaes).

pronotum The upper or dorsal surface of the prothorax.

prothorax The first thoracic segment bearing anterior legs but no wings.

proximal The region nearest the body (see Macrosiphum euphorbiae, Drepanaphis acerifoliae).

pterostigma (also called stigma) A thickened, opaque spot on the costal margin of the wing (see Mindarus abietinus). 
radial sector A short vein arising from the pterostigma and running toward the wing apex (see Mindarus abietinus, Calaphis betulaecolens).

reticulation A network of lines; meshed; a honeycomb configuration (see Chaitophorus populifolii neglectus).

sclerite A hardened, usually pigmented area of an insect's body (see Rhopalosiphum maidis, Nasonovia (Kakimia) cynosbati).

sensorium (pl. sensoria) A circular opening covered by a membrane; an olfactory organ found on the antenna.

setae Hairs (see Cinara sp., Periphyllus lyropictus).

siphunculus (pl. siphunculi) The dorsal tube or pore on the abdomen, found between terga V and VI.

sternite A hardened, pigmented area on the ventral side of an insect's body.

\section{stigma See pterostigma.}

tarsus (pl. tarsi) The foot; a jointed appendage attached at the apex of the tibia. bearing the claws. The tarsus consists of not more than 2 segments in aphids (see Trama rara).

tergum (pl. terga) The upper or dorsal surface of any body segment, usually pertaining to the abdomen.

thoracic Pertaining to the thorax.

thorax The second part of the body of an insect, between the head and the abdomen, bearing the legs and wings.

tibia (pl. tibiae) The segment of the leg between the femur and the tarsus.

transverse From side to side.

truncate Short, stump-like (see Chaitophorus populicola).

tubercles Small, usually unpigmented structures having discrete margins (sec Asiphonaphis pruni).

ventral Located on the underside.

wax plates A characteristic arrangement of wax-secreting glands (see Pemphigus sp., Tetraneura sp.. Grylloprociphilus imbricator). 


\section{Bibliography}

Basky, Z. 1984. A key to the identification of alate aphids caught in yellow pan traps. (Hungarian; translated into English). Novenyvedelem 20(9):403-414.

Blackman, R.L.; Eastop, V.F. 1984. Aphids on the world's crops: an identification and information guide. John Wiley and Sons, Chichester, U.K. 466 pp.

Cottier, W. 1953. Aphids of New Zealand. N.Z. Department of Scientific and Industrial Research. Bull. 106. 382 pp.

Eastop, V.F.; Hille Ris Lambers, D. 1976. Survey of the world's aphids. Junk, The Hague, The Netherlands. 573 pp.

Foottit, R.G.; Richards, W.R. 1993. The genera of aphids of Canada. Homoptera: Aphidoidea and Phylloxeroidea. The insects and arachnids of Canada, Part 22. Agric. Can. Publ. 1885. 766 pp.

Heie, O. 1979. Revision of the aphid genus Nasonovia Mordvilko, including Kakimia Hottes \& Frison, with keys and descriptions of the species of the world. Entomol. Scand. Suppl. 9. 105 pp.

Heie, O.E. 1980. The Aphidoidea (Hemiptera) of Fennoscandia and Denmark. I. Fauna Entomol. Scand. 9. 236 pp.

Heie, O.E. 1982. The Aphidoidea (Hemiptera) of Fennoscandia and Denmark. II. Fauna Entomol. Scand. 11. 176 pp.

Heie, O.E. 1986. The Aphidoidea (Hemiptera) of Fennoscandia and Denmark. III. Fauna Entomol. Scand. 17. 314 pp.

Hille Ris Lambers, D. 1939. On some Western European aphids. Zool. Meded., Leiden 22:79-119.

Hille Ris Lambers, D. 1949. Contributions to a monograph of the Aphididae of Europe IV. The genera Aulacorthum Mordv., 1914; Microlophium Mordv., 1914; Hyalopteroides Theob., 1916; Idiopterus Davis, 1909; Pentalonia Coquerel, 1859; Amphorophora Buckton, 1876; Wahlgreniella nov. gen.; Megoura Buckton, 1876; Megourella nov. gen.; Hyperomyzus Börner, 1933; Nasonovia Mordv., 1914. Temminckia 8:182-324.

Hille Ris Lambers, D. 1953. Contributions to a monograph of the Aphididae of Europe. V: The genera Rhopalosiphoninus Baker, 1920; Eucarazzia Del Guercio, 1921; Rhopalomyzus Mordv., 1921; Chaetosiphon Mordv., 1914; Cryptomyzus Oestl., 1922; Pleotrichophorus Börner, 1930; Capitophorus V.D. Goot, 1913. Temminckia 9:1-177. 
Jacky, F.; Bouchery, Y. 1980. Atlas des formes ailées des espèces courantes de pucerons. Station de zoologie, Colmar. Robert Louis, Brussels, Belgium. 48 pp.

Kono, T.; Papp, C.S. 1977. Handbook of agricultural pests. State of California Department of Food and Agriculture, Sacramento, Calif. 205 pp.

MacGillivray, M.E. 1968. A review of twelve aphid species described as new by Edith M. Patch. Ann. Entomol. Soc. Am. 61:338-362.

Martin, J.H. 1983. The identification of common aphid pests of tropical agriculture. Trop. Pest Manage. 29:395-411.

McLeod, D.G.R.; Lowery, D.T. 1989. Aphids infesting crucifers in Canada. Agric. Can. Publ. 1835/E. 15 pp.

Medler, J.T.; Ghosh, A.K. 1969. Keys to species of alate aphids collected by suction, wind, and yellow-pan water traps in the North Central States, Oklahoma and Texas. North Central Regional Publication. Univ. Wis. Madison Coll. Agric. Life Sci. Res. Div. Res. Bull. 277:1-99.

Miyazaki, M. 1987. Pages 1-24 in Minks, A.K.; Harrewijn, P., eds. World crop pests: aphids-their biology, natural enemies and control. Vol. A. Elsevier, Amsterdam, The Netherlands.

Nielsson, R.J.; Habeck, D.H. 1971. The genus Hyalomyzus (Homoptera: Aphididae), with the description of a new species. Ann. Entomol. Soc. Am. 64:883-887.

Palmer, M.A. 1952. Aphids of the Rocky Mountain region. The Thomas Say Foundation, Vol. V. 452 pp.

Quednau, F.W. 1971. New and little-known aphids (Homoptera: Aphididac) from eastern North America. Can. Entomol. 103: 1083-1 106.

Richards, W.R. 1958. A new aphid genus (Homoptera: Aphididae). Fla. Entomol. 41:169-171.

Richards, W.R. 1960. A synopsis of the genus Rhopalosiphum in Canada (Homoptera: Aphididae). Can. Entomol. 92. supp. 13.51 pp.

Richards, W.R. 1965. The Callaphidini of Canada (Homoptera: Aphididae). Mem. Entomol. Soc. Can. 44. 149 pp.

Richards, W.R. 1967. The Pterocomma of Canada and Greenland with notes on the phyletic position of the Pterocommatini (Homoptera: Aphididae). Can. Entomol. 99:1015-1040. 
Richards, W.R. 1969. A revicw of the holarctic genus Roepkea with descriptions of four new nearctic species (Homoptera: Aphididae). Can. Entomol. $101: 1121-1162$.

Richards, W.R. 1972. The Chaitophorinae of Canada (Homoptera: Aphididae). Mem. Entomol. Soc. Can. 87. 109 pp.

Robinson, A.G. 1964. Asiphonaphis Wilson and Davis in North America (Homoptera: Aphididae). Can. Entomol. 96:1093-1097.

Smith, C.F.; Dillery, D.G. 1968. The Genus Drepanaphis Del Guercio (Homoptera: Aphididae). Ann. Entomol. Soc. Am. 61:185-204.

Smith, C.F. 1974. Keys to and descriptions of the genera of Pemphigini in North America (Homoptera: Aphididae: Pemphiginae). North Carolina Agric. Ex. Stn. Tech. Bull. No. 226. 61 pp.

Stroyan, H.L.G. 1984. Aphids - Pterocommatinae and Aphidinae (Aphidini). Handbook for the Identification of British Insects. 2. London. 232 pp.

Taylor, L.R.; Palmer, J.M.P.; Dupuch, M.J.; Cole, J.; Taylor, M.S. 1984. A handbook for aphid Identification. Rothamsted Experimental Station, Hertfordshire, U.K. 171 pp.

Torre-Bueno, de la, J.R. 1985. A glossary of entomology. New York Entomological Society, New York, N.Y. 336 pp.

Voegtlin, D. 1984. Notes on Hyadaphis foeniculi and redescription of Hyadaphis tataricae (Homoptera: Aphididae). Gr. Lakes Entomol. 17:55-67.

Wilson, H.F. 1911. Two new genera and seven new species of the family Aphididae. Can. Entomol. 43:59-65. 



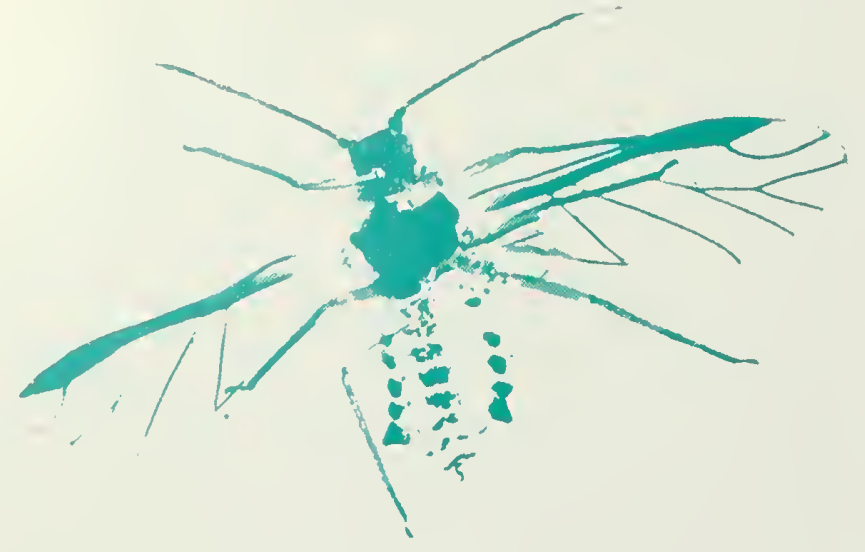

Canadä 